WILENMANN, Javier. "Injusto y agresión en la legítima defensa. Una teoría jurídica de la legítima defensa".

Polít. crim. Vol. 10, № 20 (Diciembre 2015), Art. 7, pp. 622-677.

[http://www.politicacriminal.cl/Vol_10/n_20/Vol10N20A7.pdf]

\title{
Injusto y agresión en la legítima defensa. Una teoría jurídica de la legítima defensa*
}

\section{Wrongdoing and aggression in self-defense. A juridical theory of self-defense}

\author{
Javier Wilenmann von Bernath \\ Dr. Iur. Albert-Ludwig Universität Freiburg, \\ Profesor Facultad de Derecho Universidad Adolfo Ibáñez \\ jwilenmann@yahoo.com
}

\section{Resumen}

El presente artículo constituye una reconstrucción de las bases de la dogmática de la legítima defensa, en particular, de su fundamento sustantivo y de su posición sistemática. A partir de una exposición crítica de la discusión sobre el fundamento de la legítima defensa, el artículo presenta en una primera parte una concepción de ésta basada en la idea de la agresión como contravención formal de prohibiciones constitutivas de derechos subjetivos ajenos, reconocible por medio de reglas de imputación. En una segunda parte, el artículo delimita la posición sistemática de estas reglas de aquéllas que tienen por objeto la identificación de un injusto punible. La determinación precisa del fundamento de la legítima defensa y de su posición sistemática permite de esta forma guiar su reconstrucción dogmática.

Palabras clave: Legítima defensa, agresión, injusto, reglas de imputación, responsabilidad.

\begin{abstract}
The paper exposes a reconstruction of the legal and moral foundations of the right to selfdefense in the criminal law, as well as its relationship to the idea of criminal wrongdoing. Self-defense is theoretically founded through an interpretation of the concept of threat of unlawful violence as a formal infringement of prohibitions which constitute subjective rights of others and must be therefore attributed to the responsability of the aggressor. In its second part, the article attempts to reconstruct the systematic relationship between the rules

\footnotetext{
* Este artículo ha sido desarrollado como parte del proyecto Fondecyt 11140141 sobre Justificación en situaciones de necesidad, del que el autor es el investigador responsable. El artículo fue realizado sobre la base de una ponencia realizada en el seminario de derecho penal de la Universidad Pompeu Fabra. Agradezco al Profesor Jesús Silva Sánchez por la invitación a exponer en ese contexto, así como al profesor Ivó Coca Vila. Asimismo, parte del contenido del artículo pudo ser desarrollado como parte de una estancia de investigación en el Institut für Strafrecht, Strafprozessrecht und Rechtsphilosophie de la Albert-Ludwigs Universität Freiburg. Agradezco al Prof. Dr. Dr. (h.c.) Michael Pawlik por la acogida durante la estancia de investigación.
} 
WILENMANN, Javier. "Injusto y agresión en la legítima defensa. Una teoría jurídica de la legítima defensa".

of attribution of legal responsibility (imputation) for a crime and legal responsibility for a threat of unlawful violence as a second base of the theory of the right to self-defense.

Keywords: Self-defense, threat of unlawful violence, wrongdoing, rules of attribution, responsibility.

\section{Introducción.}

La literatura sobre los fundamentos de la legítima defensa tiene un contenido que puede parecer paradójico. Por una parte, existen pocas instituciones del derecho penal, y del derecho en general, que, en su núcleo, sean tan poco controversiales como la legítima defensa. Incluso la fundamentación de la punición del homicidio - probablemente el aspecto de la Parte Especial moralmente menos controversial- puede encontrarse sujeta a la objeción de que se trata de fundamentar la imposición de un mal por la realización de un mal. No sucede lo mismo con la causación de una lesión necesaria en legítima defensa. En sus casos centrales, parece poco razonable siquiera dudar que el agredido puede defenderse frente a una agresión que compromete intereses protegidos de éste ${ }^{1}$. En ese sentido, la afirmación de que es difícilmente pensable un ordenamiento jurídico que no reconozca, al menos en principio, la permisión de la defensa necesaria para impedir el daño proveniente de una agresión, ha sido constantemente repetida en la literatura penal ${ }^{2}$. Pero, pese a ello, la pregunta por el fundamento de la legítima defensa ha tendido a ser polémica, especialmente en la literatura alemana ${ }^{3}$. Esto ha incidido, a su vez, en el tratamiento sistemático de su dogmática.

Las razones por las que la literatura alemana se ha enfrentado respecto a un punto que, en principio, parece ser trivial, no dicen relación con el núcleo de la institución en cuestión ${ }^{4}$,

\footnotetext{
${ }^{1}$ Esto ciertamente se encuentra sujeto a presupuestos culturales que hacen que, en todos los casos, esa premisa aparezca hoy como poco razonable. Correctamente PALERMO, Omar, La legítima defensa: una revisión normativista, Barcelona: Atelier, 2006, pp. 23 y ss. Sobre la historia del tratamiento jurídico de la defensa en el antiguo derecho romano y germánico, HAAS, Robert, Notwehr und Nothilfe. Zum Prinzip der Abwehr rechtswidriger Angriffe. Geschichtliche Entwicklung und heutige Problematik, Fráncfort del Meno: Peter Lang, 1978, pp. 25 y ss.

${ }^{2}$ BINDING, Karl, Handbuch des Strafrechts, Band I, Leipzig, 1885, p. 731; MAURACH, Reinhart; ZIPF, Heinz, Strafrecht Allgemeiner Teil, Tomo 1, 8a Edición, Heidelberg: C.F. Müller, 1992, § 26 Nm. 1. Véase, con ulteriores referencias, KÜHL, Kristian, "Notwehr ein Kampf ums Recht oder Streift, der misßfällt? Schlaglichter der Notwehrdiskussion der 2. Hälfte des 19. Jahrhunderts in Deutschland und Österreich", en: SCHMOLLER (Ed.) Festschrift für Otto Triffterer, Viena-Nueva York: Springer, 1996, pp. 149 y s.; EL MISMO, "Notwehr und Nothilfe", Juristische Schulung 1993, p. 177; NK-KINDHÄUSER, § 32 Nm. 7; EL MISMO, “Zur Genese der Formel 'Das Recht braucht dem Unrecht nicht zu weichen' ”, en: FREUND ET AL (Eds.), Festschrift für Wolfgang Frisch, Berlín: Duncker \& Humblot, 2013, pp. 493 y ss.; KIOUPIS, Dimitrios, Notwehr und Einwilligung. Eine individualistische Begründung, Baden-Baden: Nomos, 1992, p. 15; LUZÓN PEÑA, Diego, Aspectos esenciales de la legítima defensa, Montevideo, Buenos Aires: BdeF, 2006, p. 29.

${ }^{3}$ Véase KÜHL, "Notwehr. Ein Kampf", cit. nota n 2, pp. 150 y s.

${ }^{4}$ Acertadamente MK-ERB, § 32 Nm. 9; SCHMIDHÄUSER, Eberhard, "Die Begründung der Notwehr", Goltdammer's Archiv für Strafrecht 1991, pp. 97 y s. En contra KÜHL, "Notwehr. Ein Kampf", cit. nota n², p. 150. La opinión de Kühl puede resultar, sin embargo, sólo aparentemente contradictoria con lo aquí sostenido. Que la polémica afecte a los márgenes no quiere decir, aquí, que sea marginal, en el sentido de que
} 


\section{Polít. crim. Vol. 10, № 20 (Diciembre 2015), Art. 7, pp. 622-677. [http://www.politicacriminal.cl/Vol_10/n_20/Vol10N20A7.pdf]}

sino con la fijación de sus márgenes. El desacuerdo de la dogmática alemana se origina, en los hechos, en un gran acuerdo: una enorme mayoría de la literatura ha sostenido desde mediados del siglo XIX que el $\S 32$ StGB (antiguo $\S 53$ del Código Penal del Imperio y $\S$ 41 del Código Penal Prusiano de 1851) no reconoce ninguna limitación a la permisión de la acción ejecutada en legítima defensa, más allá de la necesidad de defenderse con el medio elegido. Lo anterior tiene, en lo esencial, tres consecuencias que no resultan en ningún sentido moralmente obvias, pero que son reconocidas casi unánimemente por literatura y jurisprudencia en Alemania: no hay obligación de ceder, esto es, pese a que el conflicto sea evitable simplemente abandonando el lugar, la acción de defensa sigue siendo considerada necesaria; no hay obligación de buscar ayuda ajena para superar el conflicto, ni siquiera con límites- ayuda estatal; la acción de defensa no se encuentra sujeta a margen de proporcionalidad alguno, pese al reconocimiento de un límite "ético-social" en caso de extrema desproporción ${ }^{5}$. En el derecho penal hispanoamericano, la cláusula de "necesidad racional del medio empleado" ha sido utilizada típicamente para introducir -sin control sistemático- criterios de proporcionalidad y subsidiariedad ${ }^{6}$. Lo laxo que ha sido el manejo jurisprudencial y doctrinal de la acción de defensa -más allá de la mucho menor densidad que en general tiene la literatura en Español- ha probablemente limitado la posibilidad de polémica sobre los fundamentos de la legítima defensa, con lo que las acusaciones de ser expresiva de una moral homicida o de caníbales no tienden a ser escuchadas ${ }^{7}$. No así en Alemania. La discusión ha sido históricamente intensa precisamente porque esa ausencia de límites requiere de una justificación que no es evidente, especialmente si se parte de premisas utilitaristas ${ }^{8}$, y esa justificación puede determinar la medida en que esa exclusión de limitaciones es reconocida.

no tenga relevancia teórica o práctica. Lo contrario es más bien cierto, precisamente porque la fijación de los márgenes precisos de la legítima defensa depende de la discusión fundamental.

${ }^{5}$ Similar KIOUPIS, Notwehr, cit. nota ${ }^{\circ} 2$, pp. 16 y ss.; NK-KINDH ̈̈USER, $§ 32$ Nm. 8. Sobre el momento histórico en la imposición de esta comprensión de la legítima defensa en Alemania véase SCHAFFSTEIN, Friedrich, Die allgemeinen Lehren vom Verbrechen in ihrer Entwicklung durch die Wissenschaft des gemeinen Strafrechts, Aalen: Scientia Verlag, 1973 (reimpresión de la edición de Berlín, 1930), pp. 78 y ss.

${ }^{6}$ Ilustrativo respecto al tratamiento más serio tradicional CÓRDOBA RODA, Juan, "Consideraciones sobre la legítima defensa”, en: GARCÍA VALDÉS ET AL (Eds.), Libro homenaje a Enrique Gimbernat, Madrid: Edisofer, 2008, p. 769: ponderando las circunstancias concretas del caso, la huida o la búsqueda de auxilio no es, en principio, exigible al agredido, pero sí reaccionar proporcionadamente. Eso no quiere decir que no existan voces que hayan intentado (sujeto a condiciones: con razón) "germanizar" la interpretación de la legítima defensa, en el sentido de someterla a puro control de necesidad. Así, por ejemplo, MOLINA FERNÁNDEZ, Fernando, Antijuridicidad penal y sistema del delito, Barcelona: Bosch, 2001, p. 400; LUZÓN PEÑA, Diego, Lecciones de Derecho Penal Parte General, Segunda Edición, Valencia: Tirant lo Blanch, 2012, 23/66ss.; CEREZO MIR, José, Curso de Derecho Penal Español Parte General, Tomo II, Sexta edición, Séptima reimpresión, Madrid: Tecnos, 2005, p. 235, este último con referencias, en la nota 113, a la gran cantidad de opiniones en contra.

${ }^{7}$ Respecto de las referencias a estas calificaciones en la literatura en alemán, véase sólo KÜHL, "Notwehr. Ein Kampf', cit. nota ${ }^{\circ}$ 2, p. 160; y NK-KINDHÄUSER, § 32 Nm. 8.

${ }^{8}$ Acertadamente KÜHL, "Notwehr. Ein Kampf", cit. nota n 2, p. 150; EL MISMO, "Notwehr und Nothilfe", cit. nota $\mathrm{n}^{\circ}$ 2, pp. 181 y ss.; PAWLIK, Michael, "La legítima defensa según Kant y Hegel”, en: MAÑALICH (Coord.), La antijuridicidad en el derecho penal, Buenos Aires: BdeF, 2013, pp. 9-10; SCHMIDHÄUSER, "Begründung”, cit. nota n 4, p. 98; KORIATH, Heinz, "Einige Gedanken zur Notwehr”, en: BRITZ ET AL, Festschrift für Heinz Müller-Dietz, Múnich: Beck, 2001, pp. 361 y s. 
WILENMANN, Javier. "Injusto y agresión en la legítima defensa. Una teoría jurídica de la legítima defensa".

En una reconstrucción dogmática cuyo interés central es presentar un esquema de reglas formalmente consistente, las que sean expresivas a la vez de fundamentos convincentes, la discusión respecto al fundamento de la legítima defensa es ineludible. Es ineludible, a su vez, tener claro que aquello que se discute dice relación ante todo con la extensión de un permiso de defensa que no incluya la imposición de una obligación de ceder ni controles materiales de proporcionalidad, al menos allí donde todavía sea convincente la defensa del reconocimiento de esta extensión. Esto hace necesario evitar la utilización de fórmulas vagas expresivas de una laxa "jurisprudencia de ponderación" como tiende a tener lugar en la literatura y en los fallos de tribunales en el mundo hispano-parlante, pero también en posturas recientes que sostienen que existe un número indeterminado de grados de responsabilidad (Zuständigkeit) por un peligro, lo que tendría un efecto reflejo en un número indeterminado de criterios de valoración material del conflicto 9 . Por correcta que esta postura sea en términos sustantivos, ella es incompatible con una orientación jurisprudencial controlable.

Junto con la pregunta por el fundamento sustantivo de sus reglas y, a partir de ello, de los márgenes de la institución, la dogmática de la legítima defensa se ha visto históricamente guiada por la confrontación en torno a su posición sistemática. Como veremos, la determinación del sentido que debe ser concedido en general a los requisitos centrales de la legítima defensa ha tendido a depender de la relación que se establece entre ésta y conceptos que pueden parecer dependientes de la teoría del hecho punible. Central a este respecto es la pregunta por la relación entre el concepto de agresión ("ilegítima" o "antijurídica") de la legítima defensa y el concepto de injusto de la teoría del hecho punible o, lo que es lo mismo, la pregunta por la relación del injusto frente al que se reacciona en legítima defensa y el injusto constitutivo (total o parcialmente) del delito. La combinación del tratamiento de ambos problemas -esto es, la interpretación sustantiva-fundamental y sistemática de la legítima defensa- puede ser así vista como hilo de Ariadna de una dogmática completa y convincente de ésta.

El presente artículo tiene por objeto tematizar exhaustivamente ambas preguntas, de modo de servir como base para una interpretación dogmática general de la legítima defensa. Para ello, en primer lugar (1) se presentará la discusión respecto al fundamento de la legítima defensa. Como veremos, la discusión que por más de treinta años fue dominante en Alemania entre teorías individualistas, supra-individualistas y dualistas, debe ser vista como problemática en sí y dependiente de una base tácita de acuerdo que resulta en sí poco convincente y a-jurídica: la teoría del interés preponderante. Una teoría propiamente jurídica de la legítima defensa requiere, por ello, deshacerse de los conceptos ligados por la base de acuerdo utilitarista. La idea de infracción formal de autonomía, que subyace a las distintas teorías que asumen que la responsabilidad es el fundamento de la legítima defensa, debe ser por ello explorada de esta forma con mayor detalle. En segundo lugar (2), se revisará la discusión sobre la posición sistemática del concepto de agresión como constitutivo del injusto de la legítima defensa. La idea de inserción sistemática del concepto de agresión en la teoría del hecho punible, esto es, la idea de que el injusto de la legítima

\footnotetext{
${ }^{9}$ PAWLIK, Michael, Der rechtfertigende Notstand, Berlín-Nueva York: De Gruyter, 2002, pp. 311-313; y LESCH, Heiko, "Die Notwehr", en: WIDMAIER/LESCH/MÜSSIG/WALLAU (Eds.), Festschrift für Hans Dahs, Colonia: Otto Schmidt, 2005, pp. 81-115, p. 97.
} 


\section{Polít. crim. Vol. 10, № 20 (Diciembre 2015), Art. 7, pp. 622-677. \\ [http://www.politicacriminal.cl/Vol_10/n_20/Vol10N20A7.pdf]}

defensa es equivalente al injusto (culpable o no culpable) del delito debe ser rechazada, ya que, como veremos, lleva a resultados insostenibles. Antes que construir un concepto de agresión a partir de la idea del injusto del delito, éste debe combinar una identificación de la autonomía formal como objeto de protección en la legítima defensa y condiciones especiales de imputación en el reconocimiento de una infracción de ésta conciliable con el fundamento de ésta.

\section{La legítima defensa como institución necesaria a la concesión normativa de ámbitos de autonomía.}

\subsection{La discusión sobre el fundamento de la legítima defensa: presentación general de las "teorías" discutidas en la literatura contemporánea.}

En la literatura de manuales, comentarios y tratados alemanes, así como en literatura hispano-parlante influida por ésta, la forma más extendida de presentación de los posibles fundamentos de la legítima defensa distingue, en lo esencial, tres acercamientos: un acercamiento individualista; un acercamiento supra-individualista, y un acercamiento, al menos hasta hace poco dominante, "dualista"10.

En lo esencial, el acercamiento individualista se diferencia respecto del acercamiento supraindividualista haciendo referencia a la pregunta por el objeto cuya defensa justificaría la concesión del permiso defensa frente a la agresión ilegítima. En la comprensión individualista, la defensa se justificaría en la protección de los bienes jurídicos individuales del agredido. En la comprensión supra-individualista, el derecho delegaría una facultad de prevención de la afectación del derecho mismo, lo que tiende a ser expresado de distintas formas (afectación y defensa de la vigencia ${ }^{11} \mathrm{o}$ de la eficacia ${ }^{12}$ del derecho, afectación y

\footnotetext{
${ }^{10}$ Una exposición organizada de esta forma de la discusión puede encontrarse en MK-ERB, § 32 Nm. 12ss.; NK-KINDHÄUSER, § 32 Nm. 9-10; MATT/RENZIKOWSKI/ENGLÄNDER, § 32 Nm. 1-4; EL MISMO, Grund und Grenzen der Nothilfe, Tubinga: Mohr-Siebeck, 2008, pp. 8ss.; KÜHL, Kristian, Strafrecht Allgemeiner Teil, 7. Edición, Múnich, Vahlen, 2012, § 7 Nm. 6ss.; MAURACH/ZIPF, AT, cit. nota $n^{\circ} 2, \S 26$ Nm. 4; OTTO, Harro, Grundkurs Strafrecht. Allgemeiner Teil, 7. Edición, Berlín: De Gruyter, 2004, $§ 8$ Nm. 17; ROXIN, Claus, "Die 'sozialethischen Einschränkungen' des Notwehrrechts -Versuch einer Bilanz -", en: Zeitschrift für die gesamte Strafrechtswissenschaft 1981, pp. 70 y ss.; LUDWIG, Dominik, "Gegenwärtiger Angriff", "drohende" und "gegenwärtige Gefahr" im Notwehr- und Notstandsrecht. Eine Studie zu den temporalen Erfordernissen der Notrechte unter vergleichender Einbeziehung der Gefahrerfordernisse des Polizeirechts, Fráncfort del Meno: Peter Lang, 1991, pp. 44 y ss. Siguiendo un esquema similar pero en perspectiva histórica LK11-SPENDEL, § 32 Nm. 13ss. Buenas exposiciones panópticas más recientes pueden encontrarse en KORIATH, "Gedanken", cit. nota n 8, pp. 368 y ss.; PAWLIK, Michael, "Die Notwehr nach Kant und Hegel”, Zeitschrift für die gesamte Strafrechtswissenschaft 2002, pp. 262-265 (= EL MISMO, Legítima defensa, cit. nota $\mathrm{n}^{\circ} 8$, pp. 3 y ss); MITSCH, Wolfgang, Rechtfertigung und Opferverhalten, Hamburgo: Kovac, 2004, pp. 325 y ss; KROß, Antje, Notwehr gegen Schweigegelderpressung, Berlín: Duncker \& Humblot, 2004, pp. 21 y ss.; y KARGL, Walter, "Die intersubjektive Begründung und Begrenzung der Notwehr”, Zeitschrift für die gesamte Strafrechtswissenschaft 1998, pp. 39 y ss. En español pueden consultarse las exposiciones, algo menos precisas en la reconstrucción de la discusión alemana, de PALERMO, Legítima defensa, cit. nota $\mathrm{n}^{\circ} 1$, pp. 31 y ss.; y LUZÓN PEÑA, Aspectos esenciales, cit. nota ${ }^{\circ}$ 2, pp. 17 y ss.

11 BITZILEKIS, Nikolaos, Die neue Tendenz zur Einschränkung des Notwehrrechts unter besonderer Berücksichtigung der Notwehrprovokation, Berlín: Duncker \& Humblot, 1984, pp. 53ss.

${ }^{12}$ SCHMIDHÄUSER, Eberhard, Strafrecht Allgemeiner Teil, 2a Edición, Tubinga: Mohr-Siebeck, 1975, 9/86.; EL MISMO, “Über die Wertstruktur der Notwehr”, en: BARTH (Ed.), Festschrift für Richard Honig,
} 
WILENMANN, Javier. "Injusto y agresión en la legítima defensa. Una teoría jurídica de la legítima defensa".

defensa del ordenamiento jurídico en sí, afectación y defensa de la idea de derecho ${ }^{13}$, etc.). De esta forma, el objeto de ataque de la agresión sería, en el caso de las teorías individualistas, el bien jurídico individual puesto en peligro, y correlativamente el objeto protegido por la acción en legítima defensa tendría que ser el mismo bien jurídico individual. En el otro, el objeto de ataque y de protección asume una composición colectiva. En la comprensión dualista, en cambio, ambos aspectos son tomados en cuenta para fundamentar la concesión de la facultad de defensa.

Sobre la comprensión individualista de la legítima defensa nos ocuparemos, en parte, más adelante, ya que algunas posiciones que son etiquetadas de esta forma deben ser consideradas claves para comprender su fundamento ${ }^{14}$. Es importante advertir, sin embargo, que la etiqueta misma "individualista" es errada y poco expresiva en la fundamentación del todo de una institución que tenga contenido siquiera conciliable con lo que entendemos por legítima defensa ${ }^{15}$. Una tesis que sea efectivamente individualista, en el sentido de señalar que no se trata de más que de la prevención de la afectación de bienes jurídicos individuales, no puede sino ser una expresión de la denominada teoría del interés preponderante en su versión sustantivamente relevante, esto es, debe ser utilitarista. De conformidad con esta teoría, todas (o casi todas) las causas de justificación encontrarían su fundamento en que la concesión del permiso de realización de la acción típica respectiva permitiría satisfacer un interés más relevante que el interés satisfecho mediante la omisión de la realización de la acción. Esta fórmula puede no ser más que la expresión de una tautología -el derecho permite hacer algo cuando prefiere que ello tenga lugar-. La versión sustantiva de la teoría del interés preponderante asume, en cambio, que se trata de una verdadera justificación moral derivada del utilitarismo que subyace al derecho: el derecho debe siempre preferir que se realicen $u$ omitan aquellas acciones que, desde el punto de vista del colectivo, satisfagan en mayor medida intereses. En la legítima defensa se trataría, de esta forma, de la concesión de un derecho de defensa cuando los bienes defendidos sean más valiosos que los bienes afectados desde el punto de vista del colectivo social ${ }^{16}$.

Gotinga, Schwartz, 1970, pp. 185-200, pp. 192 y ss.; EL MISMO, “Begründung”, cit. nota n 4, pp. 102 y ss. y 115 y ss.

${ }^{13}$ COURAKIS, Nestor, Zur sozialethischen Begründung der Notwehr. Die sozialethischen Schranken des Notwehrrechts nach deutschem und griechischem Strafrecht, Baden-Baden: Nomos, 1978, pp. 45 y ss.

${ }^{14}$ Así, por ejemplo, SINN, Arndt, "Die Notwehr als Lotteriespiel", en: FAHL ET AL (Eds.), Festschrift für Werner Beulke, Múnich: Müller, 2015, p. 277, reenvía las teorías individualista a la idea de una relación interpersonal. Si esto es una afirmación respecto a que las teorías propiamente individualistas no se distinguen de la comprensión aquí expuesta de la legítima defensa, o respecto a que una teoría individualista en realidad sólo puede "interpersonal", no es claro. El hecho de que los representantes de teorías individualistas citados por Sinn (Pawlik, Renzikowski, Koriath) cuenten entre los exponentes más convincentes de teorías de la legítima defensa en la literatura reciente, parece indicar que se trata de lo segundo.

${ }^{15}$ Similar PAWLIK, "Kant und Hegel", cit. nota n 10, p. 265 (= "Legítima defensa", cit. nota n ${ }^{\circ}$ 8, p. 14); HAAS, Volker, Kausalität und Rechtsverletzung. Ein Beitrag zu den Grundlagen strafrechtlicher Erfolgshaftung am Beispiel des Abbruchs rettender Kausalverläufe, Berlín: Duncker \& Humblot, 2002, p. 101.

${ }^{16}$ Así, en el fondo, WAGNER, Heinz, Individualistische oder überindividualistische Notwehrbegründung, Berlín: Duncker \& Humblot, 1984, pp. 29 y ss.; y KUHLEN, Lothar, "La restricción de las facultades de actuación en la legítima defensa de terceros", en: GARCÍA VALDÉS ET AL (Eds.), Estudios en homenaje a Enrique Gimbernat, Madrid: Edisofer, pp. 1104 y s. También KARGL, "Begründung", cit. nota n 10, 40-41 reconoce acertadamente que la pretensión de fundamentación individualista tiende a estar erguida sobre la base de la teoría del interés preponderante. 


\section{Polít. crim. Vol. 10, № 20 (Diciembre 2015), Art. 7, pp. 622-677. \\ [http://www.politicacriminal.cl/Vol_10/n_20/Vol10N20A7.pdf]}

Más allá de los problemas que le afectan al utilitarismo como teoría moral y de la incompatibilidad general que su aplicación directa tiene en relación con el derecho, esta comprensión es incompatible con la estructura de la legítima defensa si se asume una comprensión "individualista". Si la comparación de intereses tiene lugar de forma puramente individual -esto quiere decir: tomando en cuenta sólo los intereses individuales en conflicto- para determinar qué resulta más valioso a la sociedad, entonces todas las referencias vagas de la teoría del interés preponderante a bienes sin reflejo material (la defensa del derecho mismo) deben desaparecer, con lo que la legítima defensa no sólo constituiría un caso de estado de necesidad justificante en la comprensión amplia de la teoría del interés preponderante, sino que se confundiría por completo con el mismo ${ }^{17}$. Precisamente por ello, teorías de esta clase tienen que recurrir a criterios ad hoc para explicar aquello que caracterizaría a la legítima defensa frente al estado de necesidad ${ }^{18}$. Como reconstrucción del derecho vigente, sea en Alemania o en los ordenamientos jurídicos del mundo hispano parlante, una comprensión de este estilo es desde un inicio implausible: no puede ni siquiera explicar por qué se distingue del todo entre legítima defensa y estado de necesidad justificante.

Igualmente poco convincente es la pretensión de entregar un fundamento puramente supraindividual a la legítima defensa. La idea de que el derecho o el ordenamiento jurídico sea defendido en sí mediante un acto de defensa personal no sólo resulta fenoménicamente inverosímil $^{19}$, sino que produce una serie de problemas en la determinación de la extensión de la acción en legítima defensa. Si la legítima defensa es, en el fondo, la delegación de una facultad del Estado de actuar en defensa de sí mismo o del derecho -aquí no es demasiado relevante la pregunta central de la discusión jurídica en Alemania anterior a 1932 sobre la relación conceptual entre derecho y Estado- cuando sus funcionarios no se encuentren en condiciones de hacerlo, entonces pareciera ser razonable imponer una obligación de

\footnotetext{
${ }^{17}$ Similar SCHMIDHÄUSER, "Begründung”, cit. nota n 4, pp. 104 y s. La misma crítica es, sin embargo, aplicable a las teorías dualistas y, en alguna medida, a las teorías supra-individualistas. El problema general que explica la discusión entre teorías individualistas, supra-individualistas y dualistas ha sido la asunción de la teoría del interés preponderante bajo cuyo piso la distinción, en principio más o menos obvia, entre legítima defensa y estado de necesidad agresivo justificante es especialmente difícil de trazar. Similar VON DEN PFORDTEN, Dietmar, "Zu den Prinzipien der Notwehr", en: AMELUNG ET AL (Eds.), Festschrift für Hans-Ludwig Schreiber, Heidelberg: Müller, 2003, p. 370.

18 Ejemplar KRATZSCH, Dietrich, "Der 'Angriff' - ein Schlüsselbegriff des Notwehrrechts", Strafverteidiger 1987, pp. 228 y s.

${ }^{19}$ Así también KORIATH, "Gedanken", cit. nota n 8, p. 372, quien califica a la afirmación de la defensa del ordenamiento jurídico como "sencillamente histérica". El argumento parece ser, además, inconciliable con aquello que trata de justificar. La discusión sobre el fundamento de la legítima defensa se refiere a la extensión abstracta (ausencia de control de proporcionalidad; ausencia de obligación de ceder) de la acción permitida. Pero el ordenamiento jurídico como tal tiende a sujetar, a partir de su constitucionalización, la afectación de derechos fundamentales por parte del Estado precisamente a controles no sólo de necesidad, sino también de proporcionalidad. Como la legítima defensa es aquí interpretada como facultad delegada, la renuncia al control de proporcionalidad queda precisamente sin respuesta a partir de una interpretación de esta clase. Acertadamente PAWLIK, "Kant und Hegel", cit. nota n 10, p. 264 nota 29 (= "Legítima defensa", cit. nota $\mathrm{n}^{\circ}$ 8, p. 13 nota 29). Véanse las críticas ulteriores en PAWLIK, "Kant und Hegel”, p. 265 nota 34 (= "Legítima defensa", p. 15 nota 34); ENGLÄNDER, Nothilfe, cit. nota n 10, pp. 12 y ss.; RENZIKOWSKI, Joachim, Notstand und Notwehr, Berlín: Duncker \& Humblot, 1994, p. 234.
} 
WILENMANN, Javier. "Injusto y agresión en la legítima defensa. Una teoría jurídica de la legítima defensa”.

defensa (personal o de terceros) y no sólo un permiso de actuar ${ }^{20}$. Esta era una tesis que tuvo cierta recepción en la primera mitad del siglo $\mathrm{XIX}^{21}$, pero que ningún ordenamiento jurídico acepta hoy en día y que tampoco es defendida realmente en la literatura. La cuestión es todavía menos convincente tratándose de la legítima defensa de terceros. Si se trata de la defensa del derecho, entonces la defensa no puede quedar condicionada a la voluntad del agredido de ser defendido. No se trataría de una agresión en contra suya, sino en contra del derecho, por lo que el agente estaría facultado a intervenir incluso con su oposición $^{22}$. Los efectos de esta idea no son tan extensos como podría pensarse: en muchos casos que se tematizan bajo la etiqueta "legítima defensa impuesta",23, no hay ni siquiera agresión antijurídica por causa del consentimiento en la agresión ${ }^{24}$. Esto muestra, sin embargo, una cierta tensión valorativa: ¿por qué concede el ordenamiento jurídico tantas

${ }^{20}$ Acertadamente SK-GÜNTHER, $\S 32 \mathrm{Nm}$. 12; PALERMO, Legítima defensa, cit. nota n ${ }^{\circ} 1$, pp. 106 y ss.,
identifica adicionalmente dificultades de explicar la no concesión de legítima defensa respecto de bienes
jurídicos colectivos, siguiendo en esto a WAGNER, Notwehrbegründung, cit. nota $\mathrm{n}^{\circ} 16$, p. 18. También
resulta convincente la crítica de KARGL, "Begründung" cit. nota ${ }^{\circ} 10$, p. 46, en el sentido de que
precisamente, una vez que uno asume que el Estado monopoliza la violencia privada, sus facultades de
ejercicio de ésta deben considerarse indelegables.
${ }^{21}$ En relación a la confrontación entre razón e irracionalidad, así RICHTER, Heinrich Ferdinand, Das philosophische Strafrecht begründet auf die Idee der Gerechtigkeit, Leipzig, 1829, pp. 136 y s. Al respecto véase BERNER, Albert Friedrich, "Die Notwehrtheorie", Archiv des Criminalrechts 1848, Halle, pp. 556-558 y PAWLIK, "Kant und Hegel", cit. nota $\mathrm{n}^{\circ} 10$, pp. 296 y s., nota 184 . Berner le imputa también a MICHELET, Karl Ludwig, Das System der philosophischen Moral, Berlín, 1828, p. 161, haber defendido la idea de que el ejercicio de la legítima defensa constituye una obligación. En el trabajo mismo de Michelet no puede encontrarse, sin embargo, ninguna afirmación explícita en este sentido. La crítica de Berner puede dirigirse a la comparación entre legítima defensa y pena, en tanto restablecimiento del derecho, que al menos retóricamente es defendida por Michelet. PALERMO, Legítima defensa, cit. nota $\mathrm{n}^{\circ} 1$, p. 86, le imputa en general esta concepción a Hegel y los penalistas hegelianos, con especial referencia a Köstlin. En esto hay un error categórico. El error en la consideración de que la concepción de la legítima defensa de Hegel constituye una "defensa supraindividualista" (así como la "concepción absolutista del Estado" que Palermo atribuye a Hegel), constituye ciertamente un lugar común en la literatura contemporánea, el que como PAWLIK, "Kant und Hegel", cit. nota $\mathrm{n}^{\circ} 10$, pp. 282 y ss. (= "Legítima defensa", cita nota $\mathrm{n}^{\circ} 8$, pp. 40 y ss.), ha demostrado convincentemente, no tiene fundamento bibliográfico alguno - excepción sea hecha de algunos casos algo excéntricos como Richter. El propio Palermo reenvía, sin embargo, en la nota 238 de su libro al trabajo de Pawlik en lo que respecta a la concepción de la legítima defensa de Hegel y los hegelianos. Por ello, la confusión en cuestión es difícilmente comprensible. La referencia a KÖSTLIN es, a su vez, errada. La cita a la Neue Revision contenida en la nota 240 de la página 86 del libro de Palermo lleva precisamente a la defensa de una concepción facultativa en el ejercicio de la legítima defensa por delegación de facultades. Esto es especialmente claro, por lo demás, en su tratamiento más acabado de la legítima defensa en KÖSTLIN, Christian Reinhold, System des deutschen Strafrechts. Erste Abtheilung. Allgemeiner Theil, Tubinga, 1855, pp. 75 y ss. La legítima defensa sería asunción de facultades estatales de defensa violenta a favor del individuo en defensa de éste. Se trataría, de esta forma, de una excepción al monopolio en el ejercicio de la fuerza legítima por parte del Estado, cuyo objeto sería precisamente la defensa de derechos individuales a los que el Estado se encuentra, en principio privativamente, obligado a defender.

${ }^{22}$ SCHMIDHÄUSER, $A T$, cit. nota $\mathrm{n}^{\circ} 12,9 / 107$; BITZILEKIS, Einschränkung, cit. nota n ${ }^{\circ} 11$, pp. 72 y ss.

${ }^{23}$ El concepto de "legítima defensa impuesta" es utilizado por la dogmática penal alemana para designar actuaciones de un tercero a favor de un agredido pero contra su voluntad. En general, se considera que la legítima defensa impuesta no se encuentra justificada.

${ }^{24}$ Este es un criterio ampliamente compartido de demarcación de los casos de verdadera legítima defensa impuesta, como problema dogmático, y casos en que simplemente no hay agresión antijurídica a causa del consentimiento. Al respecto véase sólo SEEBERG, Rouven, Aufgedrängte Nothilfe, Notwehr und Notwehrexzess, Fráncfort del Meno, 2004, pp. 85 y ss. 
facultades al lesionado de definir el hecho en cuestión como agresión y no, en cambio, de definir que la agresión no sea resistida? ${ }^{25}$

De esta forma, las denominadas teorías supra-individualistas sufren, en el fondo, del mismo defecto que las teorías dualistas: se trata de intentos de explicar exclusivamente la extensión de la legítima defensa por partir, explícita o implícitamente, de un piso utilitarista. La pregunta que tienden a plantearse sus partidarios se refiere a las razones por las que el derecho permite afectaciones materialmente más lesivas para prevenir afectaciones menos lesivas. Como desde un punto de vista material esto parece ser efectivamente extraño, las teorías en cuestión recurren a un tópico de reconocimiento de intereses irresistiblemente poderosos - ¡se juega la vigencia del ordenamiento jurídico! ${ }^{26}{ }_{-}$ para explicar la aparente anomalía. El problema se encuentra, sin embargo, precisamente en abandonar la perspectiva jurídica y asumir, de esta forma, alguna comprensión de base que sea asimilable a la teoría del interés preponderante ${ }^{27}$. Que algunos de sus partidarios se hayan mostrado al mismo tiempo críticos de la teoría del interés preponderante sólo muestra el poder hermenéutico que tiene la hegemonía espiritual. Afortunadamente, el búho de Minerva ya parece haber emprendido nuevamente el vuelo.

Por supuesto, la mayor expresión de orientación asistemática y a-jurídica se encuentra en las denominadas teorías dualistas, dominantes al menos hasta principios de siglo en Alemania $^{28}$ y probablemente todavía en el mundo hispanoparlante ${ }^{29}$. Se trata -

${ }^{25}$ A este respecto véase también PALERMO, Legítima defensa, cit. nota $\mathrm{n}^{\circ} 1$, pp. 109 y ss.

${ }^{26}$ Críticos respecto a la concesión de un valor incontestable al tópico de la defensa del ordenamiento jurídico NEUMANN, Ulfried, "Individuelle und überindividuelle Begründung des Notwehrrechts", en: LÜDERSSEN ET AL (Eds.), Modernes Strafrecht und ultima-ratio Prinzip, Fráncfort del Meno: Peter Lang, 1990, pp. 222 y s; y KORIATH, “Gedanken”, cit. nota $\mathrm{n}^{\circ}$ 8, p. 371. Por lo demás, el propio ordenamiento jurídico establece amplias limitaciones centradas en proporcionalidad al ejercicio de la violencia estatal. Que en su defensa ello no deba ser respetado no parece del todo convincente, al menos no mientras no se juegue - como en prácticamente todo caso de legítima defensa - la supervivencia del Estado mismo. Similar KARGL, "Begründung", cit. nota ${ }^{\circ}$ 10, p. 46. Por último, un valor crucial de todo ordenamiento jurídico moderno es el mantenimiento del monopolio de la violencia legítima en el Estado. El otorgamiento de derechos de defensa del ordenamiento jurídico mismo a privados parece ser difícilmente compatible con esto. Así también KIOUPIS, Notwehr, cit. nota ${ }^{\circ} 2$, pp. 31 y s.

${ }^{27}$ Así también PAWLIK, "Kant und Hegel”, cit. nota n 10, pp. 262 y s. (= "Legítima defensa”, cit. nota n 8, pp. 9-11), quien rastrea las dificultades de las teorías dualistas y supra-individualistas -aunque en realidad ello se extiende a las teorías individualistas contemporáneas en varios de sus casos- a la premisa de que el estándar de valoración jurídico-penal es la defensa de bienes jurídicos, sobre cuya base, como hemos vista, se posa a su vez la teoría del interés preponderante.

${ }^{28}$ De acuerdo a SCHÖNKE/SCHRÖDER/PERRON, § 32 Nm. 2, "sigue” siendo la teoría dominante. No así, sin embargo, ROXIN, Claus, "Notwehr und Rechtsbewährung”, en: HEGER/KELKER/SCHRAMM (Eds.), Festschrift für Kristian Kühl, Múnich: Beck, 2014, p. 391, quien la califica de "al menos en el pasado dominante". Ella puede encontrarse, por ejemplo, en BGHSt 24, 356 (359); MAURACH/ZIPF, AT, cit. nota $\mathrm{n}^{\circ} 2$, § 26 Nm. 4; ROXIN, Claus, Kriminalpolitik und Strafrechtssystem, $2^{\text {a }}$ Edición, Berlín-Nueva York, De Gruyter, 1973, pp. 28 y ss.; EL MISMO, Strafrecht Allgemeiner Teil. Band I, 4ª Edición, Múnich, Beck, 2006, § 15 Nm. 1 y ss.; EL MISMO, "Einschränkungen”, cit. nota n 10, pp. 70 y ss.; LENCKNER, Theodor, Der rechtfertigende Notstand, Tubinga: Mohr-Siebeck, 1965, p. 24; THIEL, Sven-Markus, Die Konkurrenz von Rechtfertigungsgründen, Fráncfort del Meno: Peter Lang, 2000, pp. 99 y ss.; GEILEN, Gerd, "Notwehr und Notwehrexzeß", Juristische Ausbildung 1981, p. 200; KRAUSE, Friedrich-Wilhelm, "Notwehr bei Angriffen Schuldlosen und Bagatellenangriffen", en HIRSCH (ed.), Gedächtnisschrift für Hilde Kaufmann, Nueva York/Berlín: De Gruyter, 1986, pp. 674 y s.; KLEINHERNE, Philipp Christoph, Garantenstellung und 
WILENMANN, Javier. "Injusto y agresión en la legítima defensa. Una teoría jurídica de la legítima defensa”.

peyorativamente expresado- de una construcción ecléctica: ella asume, siguiendo a las denominadas teorías individualistas, que el objeto que justifica la concesión del permiso de protección es el bien jurídico individual protegido ${ }^{30}$-esto es aquello que es principalmente defendido por la acción en legítima defensa; una asunción "colectivista" sería contrario a un estado de derecho con orientación individual-, pero la renuncia a las limitaciones que normalmente debieran seguirse, de acuerdo a la teoría del interés preponderante, es explicada mediante referencia al aspecto supra-individual en cuestión ${ }^{31}$. Esto es: el ordenamiento jurídico concedería un permiso de defensa para proteger el bien jurídico individual objeto de la agresión. Sin embargo, si esto fuera sólo así, asume la teoría, entonces no se explicaría la renuncia a estándares de proporcionalidad o la no imposición de una obligación de ceder $^{32}$. El hecho de que además se defienda al ordenamiento jurídico $^{33}$, o a la vigencia empírica de la norma, o que el acto tenga efectos políticocriminales relevantes $^{34}$, sería aquello que justificaría lo que desde el punto de vista de la

Notwehrrecht, Fráncfort del Meno: Peter Lang, 2013, pp. 25 y ss.; NK3-HERZOG, Vor $\S 32$ Nm. 100; SATZGER/SCHMITT/WIDMAIER/ROSENAU, § 32 Nm. 2; SEELMANN, Kurt, Das Verhältnis von § 34 StGB zu anderen Rechtsfertigungsgründen, Heidelberg, v. Decker, 1978, pp. 30 y s.; SINN, Arndt, "Notwehr gegen nicht sorgfaltwidriges Verhalten", Goltdammer's Archiv für Strafrecht 2003, p. 97; SOWADA, "Sind zwei Halbe ein Ganzes? Zur Addierbarkeit teilverwirklichter Fallgruppen bei den sozialethischen Notwehrbeschränkungen", en: PUTZKE ET AL (Eds.), Festschrift für Rolf Herzberg, Tubinga: MohrSiebeck, 2008, p. 465; OTTO, AT, cit. nota ${ }^{\circ} 10$, § 8 Nm. 17; LACKNER/KÜHL, § 32 Nm. 1; KÜHL, AT, cit. nota $\mathrm{n}^{\circ} 10, \S 7 \mathrm{Nm}$. 6-13; EL MISMO, "Notwehr und Nothilfe", cit. nota $\mathrm{n}^{\circ} 2$, pp. 179 y s.; FISCHER, Thomas, Strafgesetzbuch Kommentar, 62 Edición, Múnich: Beck, 2015, § 32 Nm. 2; JESCHECK, HansHeinrich y WEIGEND, Thomas, Lehrbuch des Strafrechts Allgemeiner Teil, $5^{\text {a }}$ Edición, Berlín, Duncker \& Humblot, 1996, p. 337; VAN RIENEN, Rafael, Die "sozialethischen" Einschränkungen des Notwehrrechts. Die Grenzen privater Rechtsverteidigung und das staatliche Gewaltmonopol, Baden-Baden: Nomos, 2009, pp. 138 y ss.; PELZ, Christian, "Notwehr- und Notstandsrechte und der Vorrang obrigkeitlicher Hilfe", Neue Zeitschrift für Strafrecht 1995, pp. 307 y s.

${ }^{29}$ Véase ante todo LUZÓN PENAA, Aspectos esenciales, cit. nota ${ }^{\circ} 2$, pp. 44 y ss., 64 y ss.; EL MISMO, Lecciones de Derecho Penal Parte General, Segunda Edición, Valencia: Tirant lo Blanch, 2012, 23/4-6; EL MISMO, Curso de Derecho Penal Parte General I, Madrid, 1996, pp. 587 y s. Similar BACIGALUPO, Enrique, Derecho Penal Parte General, 2a Edición, Buenos Aires: Hammurabi, 1999, § 51 Nm. 695; BUSTOS, Juan, Manual de Derecho Penal Español Parte General, Barcelona: Ariel, 1984, p. 232; BUSTOS, Juan; HORMAZABAL, Hernán, Lecciones de Derecho Penal, Volumen II, Madrid: Trotta, 1999, p. 121; CEREZO MIR, Curso II, cit. nota n ${ }^{\circ}$ 6, pp. 207 y s. (con referencias a la jurisprudencia española en la nota 1); COBO DEL ROSAL, Manuel, y VIVES ANTÓN, Tomás, Derecho Penal Parte General, $3^{\mathrm{a}}$ Edición, Valencia: Tirant lo Blanch, 1991, p. 384; GARRIDO MONTT, Mario, Derecho Penal, Parte General, Tomo II, Tercera Edición, Santiago: Editorial Jurídica, 2003, pp. 127 y s.; JIMÉNEZ DÍAZ, María José, El exceso intensivo en la legítima defensa, Granada: Comares, 2007, pp. 5 y ss.; MIR PUIG, Santiago, Derecho Penal Parte General, Novena Edición actualizada por GÓMEZ MARTÍN, Barcelona: Reppertor, 2011, 16/39. El calificativo de "dominante" de las teorías dualistas en el mundo hispano-parlante es expresamente defendido por PALERMO, Legítima defensa, cit. nota ${ }^{\circ} 1$, pp. 137-138 con referencias en la nota 469.

${ }^{30}$ Con particular explicitación a este respecto ROXIN, "Rechtsbewährung", cit. nota $n^{\circ} 28$, pp. 392 y ss.: la fundamentación dualista de la legítima defensa expresaría que se trata ante todo de la defensa de bienes jurídicos individuales y no de ejercicio policial o incluso penal delegado por parte del Estado.

${ }^{31} \mathrm{KÜHL}, A T$, cit. nota $\mathrm{n}^{\circ} 10, \S 7 \mathrm{Nm} .11$.

${ }^{32}$ Véase sólo ROXIN, "Einschränkungen", cit. nota n 10, 70-72; KÜHL, "Notwehr und Nothilfe", cit. nota $\mathrm{n}^{\circ}$ 2, pp. 181 y ss.; y EL MISMO, "Notwehr. Ein Kampf", cit. nota n 2, p. 150.

${ }^{33}$ Esta es la fórmula tradicional, expresada en alemán mediante el concepto (o principio) de protección del derecho (Rechtsbewährungsprinzip). Así, entre nosotros, LUZÓN PEÑA, Aspectos esenciales, cit. nota $\mathrm{n}^{\circ} 2$, p. 79.

${ }^{34}$ ROXIN, Kriminalpolitik, cit. nota ${ }^{\circ}$ n. 28, pp. 28-33; EL MISMO, AT, cit. nota ${ }^{\circ}$ 28, § 15 Nm. 56s.; EL MISMO, "Einschränkungen", cit. nota ${ }^{\circ} 2$, pp. 73 y ss. Cercano HOYER, Andreas, Strafrechtsdogmatik 
teoría del interés preponderante, sobre cuya base se posa en buena medida la teoría dualista, parece contra-intuitivo. En cambio, en los casos de las denominadas limitaciones éticosociales, el tópico de la protección del derecho es utilizado para mostrar su menor compromiso y, por ello, la falta de justificación sustantiva en la aplicación de la legítima defensa en todo su rigor ${ }^{35}$.

Las teorías dualistas hacen, de esta forma, un uso tópico de la figura de la defensa del ordenamiento jurídico para explicar extensiones y limitaciones que hoy en día son generalmente aceptadas en la dogmática penal alemana ${ }^{36}$. Los aspectos más problemáticos relativos a la renuncia a la ponderación de intereses y a la ausencia de una obligación de ceder son explicados por referencia a la importancia de la defensa del ordenamiento jurídico $^{37}$. En el caso de la aparente renuncia a la proporcionalidad, las teorías dualistas sostienen que en realidad la legítima defensa incorpora una ponderación de esta clase, pero que salvo en caso de extrema desproporción, el hecho de que el ordenamiento jurídico sea defendido por el agente en legítima defensa haría que la balanza se incline siempre hacia su lado. En el caso de la ausencia de una obligación de ceder, ella se explicaría por el hecho de que, a diferencia de los bienes jurídicos individuales, el ordenamiento jurídico o el interés preventivo-general no podría verse satisfecho si el agresor se sale con la suya. En cambio, en los casos de limitaciones especiales, como en la provocación o en la sujeción a estándares de proporcionalidad por consideraciones ético-sociales frente a inimputables ${ }^{38}$, las teorías dualistas sostienen que precisamente el hecho de que aquí se juegue en menor medida la defensa del interés colectivo explicaría la inclusión de límites de proporcionalidad y de una obligación de ceder.

La implausibilidad de la teoría central sobre la que reposa la construcción dualista -la comprensión de las causas de justificación y, en particular, de las causas de justificación derivadas de situaciones de necesidad bajo la teoría del interés preponderante-, así como el poco potencial explicativo que tiene una referencia a la protección del derecho, son ciertamente razones suficientes para abandonar estas teorías. A ellas les aquejan, sin embargo, una serie de deficiencias internas que han sido descritas varias veces en las últimas décadas, pero que puede ser relevante recordar aquí ${ }^{39}$.

En primer lugar, las teorías dualistas afirman tener potencial fundamental explicativo -y, en ese sentido, ser sintéticamente relevantes-, pero al igual que la teoría del interés preponderante, asumen usualmente la forma de explicaciones analíticas (esto es, sin entrega de información fundamental). Su función consiste exclusivamente en presentar una

nach Armin Kaufmann. Lebendiges und Totes in Armin Kaufmanns Normentheorie, Berlín: Duncker \& Humblot, 1997, pp. 212-214. Una buena exposición de las críticas respecto a esta comprensión del aspecto supra-individual de la legítima defensa puede encontrarse en ENGLÄNDER, Nothilfe, cit. nota $\mathrm{n}^{\circ} 10$, pp. 1518.

${ }^{35}$ A este respecto véase sólo SINN, "Lotteriespiel”, cit. nota n 14, pp. 277 y s.

${ }^{36}$ Asì también PAWLIK, "Kant und Hegel”, cit. nota n 10, pp. 260 y s. (= "Legítima defensa", cit. nota n 8, pp. 7-9).

${ }^{37}$ ROXIN, "Einschränkungen", cit. nota $\mathrm{n}^{\circ} 10, \mathrm{p} .77$.

${ }^{38}$ ROXIN, "Einschränkungen", cit. nota $n^{\circ} 10$, pp. 81 y ss.

${ }^{39}$ Una exposición resumida de algunas de las críticas que tiende hacerse a las teorías dualistas puede encontrarse en VON DEN PFORDTEN, "Prinzipien”, cit. nota n 17, pp. 363 y ss. 
WILENMANN, Javier. "Injusto y agresión en la legítima defensa. Una teoría jurídica de la legítima defensa".

explicación de algo así como cuatro aspectos de la comprensión dominante en Alemania de la legítima defensa (ausencia de obligación de ceder y de buscar ayuda, ausencia de control de proporcionalidad, limitación ante inimputables y en caso de provocación) a través de la inclusión de un tópico (la protección del derecho) que es ajeno a su punto de partida utilitarista y materialista (esto es, el saldo de intereses socialmente construido que permite calificar una acción como correcta o incorrecta debiera hacerse, en principio, en base a intereses con alguna manifestación material). La extensión de la relevancia del tópico de la protección del derecho es de esta forma determinado por ciertos elementos preestablecidos. Con ello, mientras bajo la lógica deductiva con la que opera, los casos en cuestión debieran verse explicados por los principios de fundamentación de la legítima defensa, en realidad la cuestión opera también a la inversa: el contenido del tópico de la protección del derecho es fijado precisamente por los resultados que éste debiera explicar ${ }^{40}$. En segundo lugar, al operar sobre la base de una supuesta dialéctica de dos principios para explicar los contornos de la institución, la teoría dualista debiera contener algún criterio que permita manejar las condiciones de relevancia de cada uno de los principios y, en su caso, incluso la posibilidad de un conflicto entre ambos en la determinación de las consecuencias que se siguen de una agresión. En tanto explicación tópica centrada sólo en algunos casos, la teoría dualista no se encuentra en posición de hacerlo ${ }^{41}$, lo que ha sido reconocido incluso por sus partidarios ${ }^{42}$. De acuerdo a sus defensores, sólo sería reconocible una situación de legítima defensa si la agresión implica tanto una puesta en peligro de un bien jurídico individual y del aspecto supra-individual. Sin embargo, precisamente el caso respecto a cuya explicación se construye la teoría -la agresión en la cual la realización del daño es evitable huyendo- implica afectación sólo de lo que los partidarios de la teoría dualista denominan aspecto supra-individual, ya que la lesión al bien jurídico puede evitarse huyendo ${ }^{43}$.

La discusión reciente sobre el fundamento de la legítima defensa se ha visto afectada ante todo por las categorías explicativas que utiliza: se trata de formas de etiquetación hechas, muchas veces inconscientemente, desde el piso de la teoría del interés preponderante ${ }^{44}$. No es suficiente, con ello, afirmar que las teorías dualistas estén en repliegue y que las teorías individualistas vuelvan a estar alza ${ }^{45}$. Es ciertamente correcto identificar una enorme presión dogmática sobre las hace apenas 30 años apenas criticadas teorías dualistas, pero el salto a la afirmación de que entonces las teorías "individualistas" comienzan a volver a ser dominantes, mantiene, en el fondo, el problema central tal como estaba. Buena parte de las teorías con auto-comprensión individualista adolecen de una falta de poder de convicción

\footnotetext{
${ }^{40}$ PAWLIK, "Kant und Hegel", cit. nota $n^{\circ}$ 10, p. 261 (= "Legítima defensa", cit. nota $n^{\circ}$ 8, pp. 7-9); RENZIKOWSKI, Notstand, cit. nota $\mathrm{n}^{\circ} 19$, p. 117; WAGNER, Notwehrbegründung, cit. nota $\mathrm{n}^{\circ} 16$, p. 9; BITZILEKIS, Einschränkung, cit. nota $\mathrm{n}^{\circ} 11$, p. 48; KORIATH, "Gedanken", cit. nota ${ }^{\circ}$ 8, p. 369; KRAUSS, Detler, “'Das Recht braucht dem Unrecht nicht zu weichen' ”, en: PAEFFGEN ET AL (Eds.), Festschrift für Ingeborg Puppe, Berlín: Duncker \& Humblot, 2011, pp. 640s. Acertadamente entre nosotros, así también PALERMO, Legítima defensa, cit. nota $\mathrm{n}^{\circ} 1$, p. 151.

${ }^{41}$ Acertadamente KARGL, "Begründung", cit. nota n ${ }^{\circ}$ 8, p. 40; PAWLIK, "Kant und Hegel", cit. nota $n^{\circ}$ 10, p. 261 (= "Legítima defensa", cit. nota ${ }^{\circ} 8$, pp. 7-9); ENGLÄNDER, Nothilfe, cit. nota n ${ }^{\circ} 10$, pp. 29 y s.; PALERMO, Legítima defensa, cit. nota $\mathrm{n}^{\circ} 1, \mathrm{p} .151$.

${ }^{42}$ KÜHL, $A T$, cit. nota $\mathrm{n}^{\circ} 10, \S 7 \mathrm{Nm}$. 11; EL MISMO, "Notwehr und Nothilfe", cit. nota ${ }^{\circ}$ 2, pp. 180 y s.

${ }^{43}$ MATT/RENZIKOWSKI/ENGLÄNDER, § 32 Nm. 3; ENGLÄNDER, Nothilfe, cit. nota n 10, p. 30.

${ }^{44}$ En el fondo similar KARGL, "Begründung", cit. nota ${ }^{\circ}$ 8, pp. 39 y ss.

${ }^{45}$ Así, sin embargo, MATT/RENZIKOWSKI/ENGLÄNDER, § 32 Nm. 4.
} 
asimilable a las teorías supra-individualistas o dualistas. El movimiento que se ha experimentado en los últimos años, en el sentido de abandonar las fórmulas de justificación utilizadas entre los años 60 y 90, sugiere más bien abandonar del todo la clasificación todavía omnipresente entre teorías individualistas, supra-individualistas y dualistas, y volver a teorías con un potencial jurídico y filosófico-político mayor, las que eran comúnmente conocidas antes del inicio de la marcha triunfal de la clasificación en cuestión. $^{46}$

Por ello, antes de concentrarse en entregar una descripción de fundamentos que al autor le parezcan convincentes, parece conveniente empezar por generar formas de clasificación más precisas. Un intento en este sentido ha sido llevado a cabo por Wolfgang Mitsch ${ }^{47}$, de acuerdo al cual la clasificación debiera más bien concentrarse en la perspectiva que se asume para dar cuenta del fundamento (social, individual del agredido o individual del agresor) y de los aspectos específicos que desde ese punto de vista justifican el reconocimiento del permiso. Adaptando la clasificación de Mitsch, uno puede clasificar correctamente las teorías en cuestión en relación con el momento teórico que permitiría explicar la peculiar extensión del permiso que el ordenamiento jurídico reconoce en una situación de legítima defensa. Los momentos que, de acuerdo a lo que puede observarse en la dogmática, parecen jugar este rol, son: (i) el aspecto supra-individual que, junto con los bienes jurídicos amenazados, se vería comprometido/defendido en una situación de legítima defensa - esta es la asunción que recorre a las teorías supra-individualistas o dualistas y que ya ha sido criticado; (ii) la particular intensidad en la afectación de los bienes del agredido, o de su autonomía, que supone la agresión ilegítima; (iii) consideraciones relativas a las condiciones bajo las cuales se reconocen los límites justificados por la figura del contrato social; (iv) el control sobre el suceso que tiene el destinatario de la acción defensiva; o (v) la cualidad injusta de la agresión.

Con excepción del punto (i) y, en parte, del punto (iv), todas las teorías en cuestión se concentran en mayor o menor medida en la relación individual entre agresor y agredido. Por ello, desde el punto de vista de la etiquetación ahora tradicional, éstas tienden a ser catalogadas como "individualistas"; esta es la razón por la que el uso de estas formas de argumentación es considerado a veces "una vuelta a teorías individualistas". Esta etiquetación sólo es correcta, sin embargo, tratándose de la clase de teorías que pueden ser descritas mediante (ii): al poner el acento exclusivamente en la posición del agredido, las teorías en cuestión no pueden evitar caer en psicologismos respecto a la peculiar posición de presión en que se encontraría el agredido, o algo similar, y con ello en las críticas que afectan a las verdaderas teorías individualistas ${ }^{48}$. En cambio, en los casos de las teorías (iii),

\footnotetext{
${ }^{46}$ En este sentido también NK-KINDHÄUSER, § 32 Nm. 11ss.; PAWLIK, "Kant und Hegel”; cit. nota n 10 , pp. 266, 286-287 (= "Legítima defensa”, cit. nota n 8, pp. 14-15, 46-47); KORIATH, "Gedanken”, cit. nota n 8, pp. 374 y ss.; KARGL, "Begründung”, cit. nota n. 8, pp. 43 y ss. Más lejos VON DEN PFORDTEN, "Prinzipien", cit. nota ${ }^{\circ} 17$, pp. 366 y ss., quien mantiene el calificativo de "individualista".

${ }^{47}$ En todo MITSCH, Rechtfertigung, cit. nota ${ }^{\circ} 10$, pp. 325 y ss. Similar también KORIATH, "Gedanken”, cit. nota $\mathrm{n}^{\circ} 8$, pp. 374 y ss.; LUDWIG, Angriff, cit. nota ${ }^{\circ} 10$, pp. 73 y ss.

48 Dentro de esta categoría caben tanto teorías con marcado acento psicológico, como WAGNER, Notwehrbegründung, cit. nota $\mathrm{n}^{\circ} 16$, pp. 33 y ss., como otras clases de teorías que intentan mostrar como ciertos derechos particulares del agredido se verían involucrados en la agresión, tales como la autodeterminación (STRATENWERTH, Günther, "Prinzipien der Rechtfertigung", en Zeitschrift für die
} 
WILENMANN, Javier. "Injusto y agresión en la legítima defensa. Una teoría jurídica de la legítima defensa".

(iv) y (v), éstas se concentran en la relación de las posiciones jurídicas involucradas y no, en cambio, en los bienes jurídicos individuales comprometidos, por lo que en ese sentido puede decirse que se trata de teorías "interpersonales" o, mejor, de teorías jurídicas 49 .

Siguiendo a Mitsch, uno puede de esta forma clasificar las teorías en cuestión dependiendo de la parte de las estructuras jurídicas comprometidas en las que se concentra la teoría al explicar el fundamento de la extensión de la acción de defensa: en la posición del agredido frente al agresor (teorías individualistas en sentido estricto); en la posición del agredido frente al Estado en relación con el agresor (teorías del contrato social); o en la posición del agresor frente al agredido (teorías del injusto). Como veremos, sólo la última posición puede resultar correcta, por lo que nos concentraremos en analizarla en la próxima sección. Antes de hacerlo, sin embargo, es importante dar cuenta de la clase de teorías que aún no ha sido analizada, a saber, aquéllas que se concentran en dar cuenta de la condición de excepción al contrato social que la legítima defensa tendría.

La probablemente más famosa fundamentación de la legítima defensa desde el punto de vista de la posición frente al Estado en la que se encuentra el agredido corresponde a Paul Johan Anselm Feuerbach ${ }^{50}$ : "el uso de la violencia privada por parte de un ciudadano para proteger sus derechos contra una injuria ya iniciada bajo la condición de que la defensa por parte del Estado no sea posible, se llama legítima defensa. ${ }^{51}$. La razón por la que imposibilidad de defensa estatal y permiso de auto-defensa son conectados tan directamente en la definición de Feuerbach, dice relación con el fundamento que él mismo creía reconocer en ésta. La legítima defensa se caracterizaría por dar lugar a un restablecimiento del derecho natural a la defensa, ya que la condición de la delegación de éste en el soberano -el fundamento del deber de obediencia es la protección- no se cumpliría en su ausencia ${ }^{52}$. Con ello, la posición del agresor frente al agredido sería la de un objeto ajeno al derecho, respecto al cual la actuación jurídica no se encontraría calificada. Ello implica que en principio no se justificaría la imposición de ninguna limitación a la facultad de lesionarlo. Como se trata, sin embargo, del reconocimiento de una verdadera situación de renuncia del

gesamte Strafrechtwissenschaft 1956, pp. 64 y ss.) o la personalidad misma (NEUMANN, "Begründung", cit. nota $\mathrm{n}^{\circ} 26, \mathrm{p}$. 225). Por supuesto, los dos últimos casos tienen un germen de verdad, pero mantienen el error categorial de considerar los derechos como bienes afectados. Véanse a este respecto las críticas de KORIATH, "Gedanken", cit. nota ${ }^{\circ}$ 8, p. 376; VON DEN PFORDTEN, "Prinzipien", cit. nota $\mathrm{n}^{\circ} 17$, pp. 366-369; y ENGLÄNDER, Nothilfe, cit. nota n ${ }^{\circ}$ 10, pp. 45-50.

${ }^{49}$ El concepto es tomado de PAWLIK, "Kant und Hegel", cit. nota n ${ }^{\circ} 10$, pp. 286 y s. (= "Legítima defensa", cit. nota $\mathrm{n}^{\circ} 8$, pp. 46 y s.).

${ }^{50}$ FEUERBACH, Paul Johan Anselm, Lehrbuch des gemeinen in Deutschland gültigen peinlichen Rechts, 13. Edición, Giessen: Geyerl, 1840, § 36-37. La fundamentación de FICHTE, Johan Gottlieb, Grundlage des Naturrechts nach Prinzipien der Wissenschaftslehre, Hamburgo, 1976 (reimpresión de la $2^{\text {a }}$ Edición de Fritz Medicus, 1922), pp. 244 y s., y, de forma más bien sorprendente, de KÖSTLIN, Christian Reinhold, Neue Revision der Grundbegriffe des Criminalrechts, Tubinga, $1845 \S 188-190$ (pp. 708 y ss.), también tienen una estructura similar. Al respecto véase también WILENMANN, Javier, Freiheitsdistribution und Verantwortungsbegriff. Die Dogmatik des Defensivnotstands im Strafrecht, Tubinga: Mohr-Siebeck, 2014, pp. 432 y s. Una estructura de fundamentación de esta clase es asumida hoy, por ejemplo, por VON DEN PFORDTEN, “Prinzipien”, cit. nota n 17, pp. 370-372; o SK-GÜNTHER, § 32 Nm. 12.

${ }^{51}$ FEUERBACH, Lehrbuch, cit. nota ${ }^{\circ} 50, \S 36$ (p. 61).

${ }^{52}$ Sobre la conexión del pensamiento de Feuerbach con una reconstrucción de esta clase del derecho natural y del contrato social, véase PAWLIK, Michael, "Die Aufhebung der Strafbarkeit", en: KOCH ET AL (Eds.), Feuerbachs Bayerisches Strafgesetzbuch, Tubinga: Mohr-Siebeck, 2014, pp. 304-306. 


\section{Polít. crim. Vol. 10, № 20 (Diciembre 2015), Art. 7, pp. 622-677. \\ [http://www.politicacriminal.cl/Vol_10/n_20/Vol10N20A7.pdf]}

derecho, éste sometería su renuncia a requisitos sumamente intensos. Consecuentemente Feuerbach postulaba precisamente la existencia de una obligación y de buscar ayuda. Esto fue explícitamente establecido por éste en su Código Penal bávaro de 1813, cuyo artículo 127 establecía la no aplicabilidad de la legítima defensa en una situación de esta clase o, conforme al artículo 125, en caso que fuera del todo posible obtener ayuda estatal ${ }^{53}$.

Por cierto, las inconsistencias y las consecuencias inverosímiles a las que podía llegar Feuerbach no constituyen algo que toda teoría que se centre en la ausencia de protección estatal preventiva deba aceptar. Lo problemático en la concepción de Feuerbach es el recurso a la idea de la subsistencia normativa del estado de naturaleza en toda situación de agresión en la que el Estado no esté presente. Esta es la figura argumentativa que le confiere todo el peso de la fundamentación a la ausencia del Estado, pero que al mismo tiempo deforma la institución de la legítima defensa ${ }^{54}$. Más allá de esto, la asunción de Feuerbach tiene ciertamente un núcleo de verdad: el Estado tiene una pretensión de monopolizar la fuerza legítima $\mathrm{y}$, con ello, limita su ejercicio por parte de privados en aquellas situaciones en que es exigible esperar que éste reaccione. Ello no constituye, sin embargo, más que una condición de uso de la violencia privada legítima, usualmente reconocida en la literatura alemana con el nombre de "subsidiariedad" (frente al Estado) de los derechos de necesidad. El recurso a la privación de facultades privadas de violencia por causa de su transferencia al Estado sirve ciertamente para explicar ese requisito de la legítima defensa y del estado de necesidad, pero no contiene un potencial de justificación general de la institución.

Todas las reconstrucciones de fundamentos antes expuestas no pueden ser consideradas, por ello, satisfactorias. En lo que sigue, nos interesa explorar la forma en que asumiendo categorías interpersonales y jurídicas puede ser explicado el fundamento de la legítima defensa.

\section{2. ¿Qué justifica la concesión de un derecho de defensa formal, sin obligación de ceder?}

1.2.1. La agresión como fundamento de la legítima defensa. ¿Fundamento centrado en la posición del agresor?

\footnotetext{
${ }^{53}$ Sobre las inconsecuencias de Feuerbach en el manejo de la legítima defensa en sus distintas instancias, informa PAWLIK, "Aufhebung”, cit. nota n ${ }^{\circ}$ 52, pp. 306 y s.

${ }^{54} \mathrm{Si}$ bien entre nosotros NOVOA, Eduardo, Curso de Derecho Penal Chileno, Tomo I, Tercera Edición, Santiago: Editorial Jurídica, 2005, pp. 330 y s.; CURY, Enrique, Derecho Penal, Parte General, Octava Edición, Santiago: Ediciones Universidad Católica, 2005, pp. 273 y s.; y ZAFFARONI, Eugenio; SLOKAR,

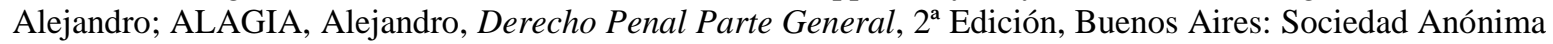
Editora, 2002, pp. 611 y s., se concentran de igual forma en la relación del agredido respecto a la defensa estatal, no recurren a una forma de fundamentación directamente ligada a la relación entre individuo y Estado como Feuerbach en la tradición de Hobbes. Eso hace que ciertamente no se trate de construcciones inverosímiles como una teoría verdaderamente centrada en esa agresión, pero imprecisas al concederle importancia fundante, y no limitante, al problema de la subsidiariedad.
} 
WILENMANN, Javier. "Injusto y agresión en la legítima defensa. Una teoría jurídica de la legítima defensa".

En algo que a la dogmática tradicional, antes del ingreso masivo y silencioso de consideraciones utilitaristas extra-jurídicas al interior de las construcciones jurídicopenales, le parecía evidente, uno debe partir de la base de que el fundamento de la legítima defensa sólo puede encontrarse en la calificación jurídica de la agresión. Esto es, por cierto, obvio ya a partir de una comparación de estructuras positivas entre legítima defensa y estado de necesidad justificante. Con ello, si bien la legítima defensa constituye un permiso establecido en beneficio del agredido, no es sólo su posición aquello que justifica la extensión de ese permiso, sino más bien la relación de ésta con la posición del agresor.

Desde el punto de vista de la clasificación de Mitsch, el hecho de que la agresión constituya la clave en la explicación de la legítima defensa sugiere asumir una fundamentación centrada en la posición del agresor y no del agredido. Con ello, una reconstrucción de la fenomenología de la relación del agresor frente al agredido podría constituir una clave en la entrega de un fundamento convincente a la legítima defensa.

Una estrategia argumentativa de esta clase fue rescatada hacia fines de los años 80 por Helmut Frister, y ha sido desarrollada con particular detalle por el propio Mitsch ${ }^{55}$. De acuerdo a ella, el fundamento de la extensión de la acción en legítima defensa -la ausencia de un deber de ceder o de consideraciones de proporcionalidad- se explicaría por el control que el agresor mantendría durante todo el iter del desarrollo de la agresión frente al agredido. Como éste mantendría siempre control sobre la su propia agresión, la lesión de sus bienes jurídicos mediante la acción defensiva podría ser evitada por éste precisamente cediendo. Este control que el agresor mantiene hasta el final sobre la lesión de sus propios bienes jurídicos justificaría la extensión del permiso en la legítima defensa.

El argumento suele ser criticado por su orientación excesivamente fenoménica y por sólo dar cuenta parcialmente de la falta de injusticia en el trato al agresor, sin entregar, sin embargo, un fundamento directo a la posibilidad de defenderse ${ }^{56}$. Pero esto es sólo parcialmente cierto. La mejor versión de este argumento, desarrollada por Mitsch ${ }^{57}$, demuestra que esta argumentación fenomenológica -en su caso etiquetado como "victimodogmática"-, si bien incompleta, tiene un potencial latente de explicación de la lógica de la legítima defensa. El argumento se encuentra construido sobre una comparación de situaciones normativas en las que se encontrarían agresor y agredido en caso de postular

\footnotetext{
${ }^{55}$ Fundamental FRISTER, Helmut, "Die Notwehr im System der Notrechte", Goltdammer's Archiv für Strafrecht 1988, pp. 300 y ss. En el mismo sentido PUPPE, Ingeborg, "Rechtfertigung und Bestimmtheit", en: KUDLICH/MONTIEL/SCHUHR (Eds.), Gesetzlichkeit und Strafrecht, Berlín, Duncker \& Humblot, 2012, pp. 168s.; PUPPE, Ingeborg, Strafrecht Allgemeiner Teil im Spiegel der Rechtssprechung, $2^{\text {a }}$ Edición, BadenBaden, Nomos, 2011, § 23 Nm. 17; MITSCH, Wolfgang, en: BAUMANN, Jürgen; WEBER, Ulrich; y MITSCH, Wolfgang, Strafrecht Allgemeiner Teil, 11 ${ }^{\mathrm{a}}$ Edición, Bielefeld: Gieseking, 2003., § 17 Nm. 1; MITSCH, Rechtfertigung, cit. nota $\mathrm{n}^{\circ} 10$, pp. 84 y ss.; y SEESKO, Tino, Notwehr gegen Erpressung durch Drohung mit erlaubtem Verhalten, Berlín: Duncker \& Humblot, 2004, pp. 110 y s. Ya antes BINDING, Handbuch, cit. nota $\mathrm{n}^{\circ} 2$, p. 737.

${ }^{56}$ Así, por ejemplo, VON DEN PFORDTEN, "Prinzipien”, cit. nota n 17, p. 369. KORIATH, "Gedanken”, cit. nota $\mathrm{n}^{\circ} 8$, p. 375 , ha criticado a su vez la imposibilidad de justificar las restricciones por extrema desproporción que se seguirían de esta concepción.

${ }^{57}$ Por cierto, parte de la argumentación de Mitsch se encuentra construido sobre un trasfondo de comparación de intereses que no resulta convincente. Al respecto véase sólo ENGLÄNDER, Nothilfe, cit. nota $\mathrm{n}^{\circ} 10$, pp. $55-57$.
} 


\section{Polít. crim. Vol. 10, № 20 (Diciembre 2015), Art. 7, pp. 622-677. \\ [http://www.politicacriminal.cl/Vol_10/n_20/Vol10N20A7.pdf]}

la existencia de un deber de ceder del agredido. Si el agredido se encontrara obligado a ceder, ello implicaría pragmáticamente la ausencia de una obligación de ceder de parte del agresor, lo que es jurídicamente inaceptable. Ejemplo: Si haciendo uso de una banca pública en un parque, A es amenazado por B con que de no cederle el uso de ésta, lo sacará a palos - pudiendo, por lo mismo, evitarse la confrontación física si A le cede el uso a B-, la imposición de una obligación de ceder de A frente a B implicaría un desconocimiento del hecho que, bajo nuestras categorías culturales y jurídicas, A tenía derecho a estar en esa posición y B no. Si A sólo pudiera defenderse en caso que no le fuera posible evitar el conflicto, por ejemplo, abandonando el lugar, entonces B no tendría una verdadera obligación de respeto, al menos en aquellas situaciones en que no haya un policía. Uno podría argumentar que el deber de respeto de la libertad de residencia de A tiene suficiente reconocimiento por el hecho de que el comportamiento de B podría resultar pese a todo punible por amenaza condicional/coacción. Pero esto tiene a su vez la forma de un argumento que sostiene, básicamente, que B tendría la obligación de dejar que la coacción no sólo haya sido intentada, sino que debe consumarse. Esto no parece ser justificable.

Aquello que justifica, de esta forma, la ausencia de un deber de ceder del agredido es precisamente el hecho de que esta ausencia sea la expresión de que, en realidad, el agresor tiene una obligación de ceder. En otras palabras: la no imposición de una obligación de ceder es la expresión de que el agresor sí tiene una obligación de ceder. ${ }^{58}$ Esto es algo que se encuentra expresado de forma especialmente clara en el fundamental trabajo de Albert Friedrich Berner: "¿Con qué derecho podría exigir el legislador que el agredido criminalmente huya frente al criminal y de esta forma pierda su derecho a permanecer en su lugar? (...) Nunca debo escapar de acuerdo al derecho absoluto, ya que simplemente ocupo el lugar en el que me encuentro con derecho. ¿Puede uno fundamentar la legítima defensa en que el derecho no debe ceder frente al injusto, y luego exigirle al titular del derecho que huya frente al agresor injusto? ${ }^{59,}$

Por cierto, el argumento de Frister y de Mitsch mantiene debilidades importantes al permanecer en una interpretación más bien fenoménica de la situación. Una expresión de este déficit se encuentra en la limitación de la legítima defensa a situaciones en las que el agresor se encuentra presente y él mismo -su cuerpo- se mantiene conectado con la agresión hasta el momento de la defensa. En los casos en que el agresor se separa de la fuente de peligro, pese a ser plenamente responsable por ella, los partidarios de esta postura tienen que considerar que sólo puede haber un estado de necesidad defensivo, ya que pierde "el control total hasta el último momento de la situación" que caracterizaría a la situación de legítima defensa. Esto es expresamente aceptado por Frister y por Puppe: si un individuo se separa del origen del peligro, por ejemplo al poner una bomba que detona mediante

\footnotetext{
${ }^{58}$ MITSCH, Rechtfertigung, cit. nota $\mathrm{n}^{\circ} 10$, pp. 351 y s. Una clara orientación normativa en este sentido puede advertirse también en FRISTER, Helmut, Strafrecht Allgemeiner Teil, 9a Edición, Múnich: Beck, 2013, $16 / 3$ s.

${ }^{59}$ BERNER, Nothwehrtheorie, cit. nota $\mathrm{n}^{\circ}$ 21, p. 578. Similar HÄLSCHNER, Hugo, Das preußische Strafrecht, Teil 2. Den allgemeinen Theil des Systems umfassend, Bonn, 1858, § 65 (pp. 252 y s.). En relación a Kant, véase también HRUSCHKA, Joachim, "Die Notwehr im Zusammenhang von Kants Rechtslehre", Zeitschrift für die gesamte Strafrechtswissenschaft 2003, pp. 219 y ss.
} 
WILENMANN, Javier. "Injusto y agresión en la legítima defensa. Una teoría jurídica de la legítima defensa".

temporizador, entonces no se trataría de una agresión ${ }^{60}$. Además, en el caso de Mitsch, la idea de que lo determinante sea ante todo la renuncia a una satisfacción cumulativa de los intereses materiales, no permite en todos los casos distinguir estado de necesidad y legítima defensa $^{61}$. Pese a estas deficiencias, la explicitación de la estructura pragmática de la relación entre agresor y agredido resulta clave para fundamentar de forma completa a la legítima defensa, partiendo ahora, sin embargo, de una comprensión propiamente jurídica que dé cuenta de la particularidad de la relación normativa entre las partes.

\subsubsection{Responsabilidad y defensa de la autonomía formal como aspectos constitutivos de la} agresión.

El punto de partida de una reconstrucción convincente del fundamento de la legítima defensa es conocido: la legítima defensa deriva su potencial explicativo de la protección de autonomía formal que tiene lugar frente a la puesta en peligro plenamente responsable por parte del agresor. Esto es lo que expresa la idea de que el principio de "autonomía" o el principio de "responsabilidad" fundamentan a la legítima defensa ${ }^{62}$. Ambas son expresiones

${ }^{60}$ FRISTER, "Die Notwehr", cit. nota ${ }^{\circ} 55$, pp. 301 y s.; PUPPE, "Rechtfertigung”, cit. nota ${ }^{\circ}$ 55, pp. 168 y s.

${ }^{61}$ Acertadamente ENGLÄNDER, Nothilfe, cit. nota ${ }^{\circ} 10$, pp. 56 y s.

${ }^{62}$ En este sentido ya HRUSCHKA, Joachim, "Extrasystematische Rechtsfertigungsgründe", en: JESCHECK y LÜTTGER (Eds.), Festschrift für Eduard Dreher, Berlín-Nueva York, 1977, pp. 198-200; EL MISMO, Strafrecht nach logisch-analytischer Methode (AT), 2a Edición, Berlín, 1988, pp. 138 y ss.; EL MISMO, "Rettungspflichten in Notstandsituationen", Juristische Schulung 1979, pp. 385 y ss.; HOYER, Andreas, "Das Rechtsinstitut der Notwehr", Juristische Schulung 1988, pp. 94-96; RENZIKOWSKI, Notstand, cit. nota ${ }^{\circ}$ 19, pp. 137-140, 181-185; JAKOBS, Günther, Strafrecht Allgemeiner Teil, $2^{a}$ Edición, Berlín-Nueva York, 1991, 11/3-3a; EL MISMO, "Kommentar: Rechtfertigung und Entschuldigung aus besonderen Notlagen (Notwehr, Notstand, Pflichtenkollision)", en: ESER; NISHIHARA (Eds.), Rechtfertigung und Entschuldigung IV, Friburgo de Brisgovia: Max Planck Institut, 1995, pp. 145 y s.; EL MISMO, Rechtszwang und Personalität, Paderborn, 2008, pp. 15 y ss.; EL MISMO, System der strafrechtlichen Zurechnung, Fráncfort del Meno, 2012, pp. 44 y ss.; PAWLIK, Notstand, cit. nota $\mathrm{n}^{\circ}$ 9, pp. 304 y ss.; EL MISMO, Das Unrecht des Bürgers, Tubinga: Mohr-Siebeck, 2013, pp. 237 y ss.; EL MISMO, "Der rechtfertigende Defensivnotstand im System der Notrechte", Goltdammer's Archiv für Strafrecht 2003, pp. 12 y ss.; EL MISMO, "Der rechtfertigende Defensivnotstand", Jura 2002, pp. 26 y ss.; STRATENWERTH, "Prinzipien", cit. nota n ${ }^{\circ} 48$, pp. 49 y ss.; MK-ERB, § 32 Nm. 18; NK-KINDHÄUSER, § 32 Nm. 18; KÖHLER, Michael, Strafrecht Allgemeiner Teil, Berlin-Heidelberg: Springer, 1997, pp. 237-238; LESCH, Heiko, Notwehrrecht und Beratungsschutz. Zur Zulässigkeit der Nohilfe gegen die nach \$218a Abs 1. StGB tatbestandslose Abtötung der Leibesfrucht, Paderborn: Ferdinand Schöningh, 2000, pp. 52-56; FREUND, Georg, Strafrecht Allgemeiner Teil. Personale Straftatlehre, Berlín-Heidelberg: Springer, 1998, § 3 Nm. 92; EUE, Jens, “Anmerkung zu BGH, Urteil v. 14.3.1989 - 1 StR 25/89 (LG Tübingen)”, JuristenZeitung 1990, pp. 765 y s.; LUDWIG, Angriff, cit. nota n ${ }^{\circ}$ 10, pp. 118 y s.; MURMANN, Uwe, Grundkurs Strafrecht, Múnich: Beck, 2011, § 15 Nm. 9; MÜSSIG, Bernd, Mord und Totschlag, Colonia-Berlín-Múnich, 2005; MERKEL, Reinhard, "Folter und Notwehr", en: PAWLIK y ZACZYK (Eds.), Festschrift für Günther Jakobs, ColoniaBerlín-Múnich, 2007, pp. 385 y ss.; LADIGES, Manuel, "Erlaubte Tötungen", Juristische Schulung 2011, p. 880; KRETSCHMER, Joachim, "Die Rechtfertigungsgründe als Topos der objektiven Zurechnung", Neue Zeitschrift für Strafrecht 2012, pp. 177 y ss.; ZIMMERMANN, Till, Rettungstötungen, Baden-Baden: Nomos, 2009, pp. 158 y ss.; SENGBUSCH, René, Die Subsidiarität der Notwehr. Zum Verhältnis der eigenhändiger Verteidigung und der Abwehr eines Angriffs durch staatliche oder private Helfer, Berlín: Duncker \& Humblot, 2008, pp. 145 y ss.; KREY, Volker; y ESSER, Robert, Deutsches Strafrecht Allgemeiner Teil, $5^{\text {a }}$ edición, Stuttgart: Kohlhammer, 2012, § 15 Nm. 622s.; KRAUß, "Unrecht”, cit. nota ${ }^{\circ}$ 40, pp. 642 y s.; CONINX, Anna, Das Solidaritätsprinzip im Lebensnotstand. Zufall, rationale Entscheidung und Verteilungsgerechtigkeit, Berna, 2012, pp. 19 y s.; ENGLÄNDER, Nothilfe, cit. nota $\mathrm{n}^{\circ}$ 10, p. 96; EL MISMO, Armin, "Die Anwendbarkeit von $\S 34$ StGB auf intrapersonale Interessenkollisionen", 
sustantivizadas del hecho de que la relación del agresor frente a los bienes jurídicos puestos en peligro se ve mediada por la existencia de prohibiciones de afectación. La agresión es en sí misma un desconocimiento de las normas, en general prohibitivas, que caracterizan la relación del agresor frente a los bienes que pone en peligro. El fundamento de la legítima defensa es simplemente ese desconocimiento normativo.

Contra las apariencias generadas por la calificación de teoría "relativa a la posición del agresor", la idea de responsabilidad como explicación del fundamento de la legítima defensa no es expresiva, de esta forma, de una pura consideración centrada en un punto de vista unilateral -este es el error que se encuentra detrás de la de otra forma muy elegantemente desarrollada concepción de Frister y Mitsch-, sino que caracteriza la relación de éste frente a la posición del agredido: que sea responsable de la vulneración de autonomía ajena significa aquí que su comportamiento puede ser visto como desconocimiento de la posición jurídica del agredido garantizada precisamente por las prohibiciones respecto a las cuales operan las reglas de imputación que permiten atribuir el calificativo de "injusto" o "incumplimiento" de ellas ${ }^{63}$. El hecho de que haya un incumplimiento de prohibiciones establecidas respecto a una posición jurídica ajena hace que el restablecimiento de la situación normativa correcta sea reconocido por el derecho. Esto es algo que puede ser fácilmente explicado por referencia a Kant: como el derecho debe ser comprendido como coacción posibilitante de la libertad externa, el ejercicio de coacción para evitar la limitación libre (es decir, en Kant, imputable; esta es precisamente la función de las reglas atributivas de responsabilidad) de la libertad externa resulta por principio legítimo: esta coacción defensiva permite, por la regla de la doble negación, el restablecimiento de la libertad externa: ${ }^{64}$ de esta forma "el derecho se encuentra conectado con la facultad de coaccionar."65

Goltdammer's Archiv für Strafrecht 2010, p. 21; JÄGER, Christian, Zurechnung und Rechtfertigung als Kategorialprinzipien im Strafrecht, Múnich, Müller, 2006, p. 31; PUPPE, AT, cit. nota n ${ }^{\circ} 55$, § 12 Nm. 1; LA MISMA, "Rechtfertigung", cit. nota ${ }^{\circ}$ 55, pp. 167 y s.; SINN, "Lotteriespiel", cit. nota no 14, pp. 272 y s.; FRISTER, "Die Notwehr", cit. nota ${ }^{\circ}$ 55, pp. 293 y ss.; EL MISMO, AT, cit. nota ${ }^{\circ}$ 58, 16/3s.; SEESKO, Notwehr, cit. nota ${ }^{\circ} 55$, pp. 110 y s.; HAAS, Kausalität, cit. nota ${ }^{\circ}$ 15, p. 101; BALDÓ LAVILLA, Francisco, Estado de necesidad y legítima defensa, Barcelona: Bosch, 1994, pp. 23 y ss.; COCA VILA, Ivó, "Entre la responsabilidad y la solidaridad. El estado de necesidad defensivo", InDret 1 (2011), pp. 17 y ss.; MAÑALICH, Juan Pablo, "Normas permisivas y deberes de tolerancia", Revista Chilena de Derecho $41 \mathrm{~N}^{\circ} 2$ (2014), pp. 513 y s.; ROBLES PLANAS, Ricardo, Estudios de dogmática jurídico-penal, Montevideo/Buenos Aires: BdeF, 2014, p. 42; PALERMO, Legítima defensa, cit. nota $\mathrm{n}^{\circ}$ 1, pp. 207 y s.;. Similar también representantes de una comprensión dualista como KÜHL, $A T$, cit. nota ${ }^{\circ} 10, \S 7$ Nm. 19ss.; EL MISMO, "Notwehr und Nothilfe", cit. nota ${ }^{\circ} 2$, pp. 182 y ss.; o BACIGALUPO, $P G$, cit. nota ${ }^{\circ} 29, \S 51 \mathrm{Nm} .695$, por referencia a Jakobs. También en el tratamiento de la legítima defensa por parte de SOLER, Sebastián, Derecho Penal Argentino, Tomo I, $5^{\text {a }}$ Edición, 10. Reimpresión, Buenos Aires: Tipográfica Editora Argentina, 1992, p. 444, hay un germen de corrección al considerar que ésta parece confundirse con la estructura misma del derecho. Ese germen se pierde, sin embargo, al conectarlo con una pretensión de prevención general.

${ }^{63}$ Insistentemente HÄLSCHNER, Strafrecht 2 , cit. nota $n^{\circ} 59$, pp. 253 y ss. Similar, aunque bajo una descripción más formal que aquí, JOERDEN, Jan, "Der Streit um die Gänsebrust. Selbsthilfe im Strafrecht", Juristische Schulung 1992, pp. 26 y s.

${ }^{64}$ KANT, Immanuel, „Metaphysik der Sitten“, en: Werkausgabe Tomo VIII, editado por WEISCHEDEL, Fráncfort del Meno: Suhrkamp, 1977, p. 339. Al respecto con mayor detalle PAWLIK, "Kant und Hegel”, cit. nota $\mathrm{n}^{\circ} 10$, pp. 266 y ss. (= "Legítima defensa", cit. nota ${ }^{\circ} 8$, pp. 15 y ss.); y HRUSCHKA, "Kants Rechtslehre“, cit. nota $\mathrm{n}^{\circ}$ 59, pp. 201 y ss. Exactamente la misma idea es expresada por Hruschka y Renzikowski al describir el origen de la autorización del ejercicio de la legítima defensa como "restauración de la relación de coordinación" jurídicamente debida. Así en HRUSCHKA, "Rechtsfertigungsgründe", cit. 
WILENMANN, Javier. "Injusto y agresión en la legítima defensa. Una teoría jurídica de la legítima defensa”.

La famosa expresión de Kant, respecto a que la idea de derecho se encuentra conectada conceptualmente con la facultad de coaccionar (a su respeto), ciertamente no aparece explícitamente vinculada por éste, al menos no en la Metafísica de las Costumbres, con la legítima defensa ${ }^{66}$. De hecho, no hay ninguna necesidad analítica de que ella conecte con facultades privadas de defensa. Al contrario, es posible que el ejercicio de esa facultad se encuentre centrada en organismos estatales. El reconocimiento de la legítima defensa es, sin embargo, precisamente el momento en que la facultad de imponer coactivamente el respeto de los derechos propios o de un tercero es reconocido a un individuo. El derecho (positivo) se encuentra así conectado con la facultad privada de coaccionar; la medida en que la máxima "el derecho se encuentra conectado a la facultad de coaccionar a su respeto" tiene reconocimiento general, sin limitación de competencias, es la legítima defensa.

Crucial en la comprensión de esta idea es advertir que se trata de una descripción de una situación que tiene dos caras que se corresponden plenamente. Parte importante de la teoría de la legítima defensa desarrollada aquí depende de la comprensión de esta idea: a la plena responsabilidad del agresor por la puesta en peligro le corresponde, interpretativamente, la afectación grave de la autonomía formal que caracteriza al "injusto" -el desconocimiento de la posición jurídica del agredido- de la legítima defensa. La agresión o el injusto son, de esta forma, una expresión de la procedencia de facultades de defensa para restaurar, cuando es necesario, una relación jurídica debida incluso mediante el uso de la fuerza. ${ }^{67}$ Por supuesto, el principal problema de fundamentación es la legitimación frente al destinatario de la acción defensiva de la facultad de lesionarlo. Pero precisamente como él es responsable de la necesidad de restaurar la relación normativa, ésta presenta un punto de apoyo en la justificación de la facultad.

nota ${ }^{\circ} 62$, pp. 196 y ss.; EL MISMO, $A T$, cit. nota $n^{\circ}$ 62, pp. 137 y ss.; RENZIKOWSKI, Notstand, cit. nota $\mathrm{n}^{\circ} 19$, pp. 224 y ss.; JOERDEN, "Gänsebrust", cit. nota $\mathrm{n}^{\circ} 63$, p. 26. Similar también KARGL, "Begründung", cit. nota n ${ }^{\circ} 10$, pp. 49 y s.; y (aparentemente) SINN, "Lotteriespiel", cit. nota n ${ }^{\circ} 14$, pp. 272s.

${ }^{65}$ KANT, "Metaphysik", cit. nota n 64, p. 338.

${ }^{66}$ Un lugar común, excesivamente extendido en la literatura chilena, consiste, sin embargo, en decir que Kant rechazaba la justificación en legítima defensa, contentándose con explicar la no punibilidad en ésta por la inutilidad de la amenaza penal frente a la necesidad del agente. Así, por ejemplo, ETCHEBERRY, Alfredo, Derecho Penal, Tomo I, $3^{\text {a }}$ edición, Santiago: Editorial Jurídica, 1997, p. 249; y NOVOA, Curso I, cit. nota ${ }^{\circ}$ 54, p. 330. En España así también RODRÍGUEZ DEVESA, José María, Derecho Penal Español Parte General, Octava edición, Madrid, sin indicación de editorial, 1981, p. 535. No es fácil rastrear el origen de este error. Aunque los manuales chilenos no citan directamente a Kant, el pasaje referido se remite claramente a las consideraciones de Kant sobre el derecho de necesidad en la Metafísica de las Costumbres, las que evidentemente no se vinculan a la legítima defensa. Esta referencia está también contenida en el manual de Rodríguez Devesa. La pregunta de Kant es, sin embargo, sólo si la necesidad de por sí puede "convertir en derecho aquello que es contrario a la ley", y no tiene ninguna relación con la legítima defensa. El malentendido parece haberse originado en la lectura de Soler, a quien se remiten tanto Etcheberry como Novoa. En la edición actual de su manual (SOLER, DP I, cit. nota $\mathrm{n}^{\circ} 62$, pp. 438 y s.), éste efectivamente conecta el pasaje del estado de necesidad contenido en la Metafísica de las Costumbres con una justificación de la legítima defensa "basada en la inutilidad de la ley penal ante necesidad", pero reconoce que "no es claro" que pueda imputarse a Kant la aplicación de este principio en la justificación de la legítima defensa, ya que el pasaje sólo se refiere al estado de necesidad vital y no habla agresión. En cualquier caso, Soler incurre nuevamente en la misma confusión al conectar la legítima defensa con la fundamentación de la justificación en estado de necesidad en el § 127 de Los Principios de la Filosofía del Derecho de Hegel.

${ }^{67}$ Acertadamente KINDHÄUSER, "Unrecht", cit. nota n ${ }^{\circ}$ 2, p. 506: "en la legítima defensa no se trata de la defensa de bienes, sino de posiciones (...).” Más lejos MK-ERB, § 32 Nm. 18. 
Pese a ello, la idea de responsabilidad y su relación con la autonomía formal permanecen todavía en un nivel demasiado abstracto. $\mathrm{Si}$, de hecho, la idea de responsabilidad no designa aquí más que la afectación de la autonomía formal, uno debiera concluir que se reproduce, al revés, el conflicto entre autonomía formal y solidaridad que caracteriza al estado de necesidad agresivo. Si esto es así, entonces la legítima defensa debiera incluir consideraciones de proporcionalidad fijadas por la medida en que la solidaridad -la consideración material del conflicto- prima sobre la autonomía formal, siendo además difícil justificar la ausencia de una obligación de ceder. Es decir, la legítima defensa sería indiferenciable del estado de necesidad defensivo. El error que tiende a ser cometido, en el sentido de considerar que la legítima defensa reproduce de forma inversa el mismo conflicto presente en el estado de necesidad agresivo ${ }^{68}$, tiene su origen en la no identificación de las particularidades que asume la idea de responsabilidad en la legítima defensa y que, de hecho, justifican la ausencia de una obligación de ceder y de control de proporcionalidad.

Nosotros nos encontramos, en cambio, en una buena posición para explicar las particularidades de la legítima defensa y de la idea de responsabilidad precisa que le sirve de fundamento. En la legítima defensa no se produce sólo una confrontación entre la producción responsable de un estado de cosas que no debe ser y consideraciones materiales relativas al conflicto, sino que la producción de ese estado de cosas tiene lugar por incumplimiento directo de una norma. La idea de responsabilidad que le subyace se ve fijada, de esta forma, por la determinación de las condiciones en que puede decirse que un sujeto no sigue mediante su acción las exigencias de una norma. El potencial justificatorio de esta particular construcción del injusto y de las reglas auxiliares que permiten determinarlo viene dado por la aplicabilidad de la figura argumentativa de la asunción: el destinatario de la agresión no puede alegar de forma convincente que fue tratado de forma injusta al ser repelida la agresión, precisamente porque puede asumirse justificadamente que él creó la necesidad de recomponer la relación jurídica debida de esta forma. Este es precisamente el sentido de la máxima hegeliana relativa a que la acción en legítima defensa constituye una ley que el agresor se ha dado a sí mismo ${ }^{69}$.

\subsubsection{La tesis de la autoría mediata.}

En la dogmática contemporánea, la idea de que el fundamento de la legítima defensa se encuentra en la plena responsabilidad del agresor por la producción de un estado de cosas antinormativo ha intentado ser explicada mediante el recurso a la figura de la autoría mediata. Esto ha sido expuesto de forma especialmente plástica por Reinhard Merkel. La autoría mediata es una institución que permite la transferencia de la responsabilidad por la realización de un hecho materialmente ejecutado por otro (el instrumento) al autor mediato. Ella opera, en general, a partir del postulado de que la responsabilidad del autor mediato por la falta de responsabilidad del instrumento es aquello que permite imputarle la autoría

\footnotetext{
${ }^{68}$ PALERMO, Legítima defensa, cit. nota $\mathrm{n}^{\circ} 1$, p. 105.

${ }^{69}$ MICHELET, System, cit. nota ${ }^{\circ}$ 21, p. 161; ABEGG, Julius, Untersuchungen zum Strafrecht, Keip: Goldbach, 1997, reimpresión de la edición publicada en Breslau, 1830, p. 122. La argumentación de Berner y, posteriormente, de Hälschner, también dependen de una concepción de esta clase, al hacer depender la cualidad de "injusto" de la idea de negación del derecho. Al respecto véase sólo NK-KINDHÄUSER, $\$ 32$ Nm. 18 .
} 
WILENMANN, Javier. "Injusto y agresión en la legítima defensa. Una teoría jurídica de la legítima defensa”.

de un comportamiento corporal fenoménicamente ajeno. En ese sentido, se trata a su vez de una construcción dogmática centrada en categorías de responsabilidad.

De acuerdo a Merkel, la legítima defensa puede ser interpretada como una forma de autolesión en autoría mediata. Con ello, incluso el caso moralmente más conflictivo, el homicidio en legítima defensa (incluso en defensa de cosas), podría ser reconstruido como un "suicidio en autoría mediata"; "considerado normativamente, el agresor se da muerte a sí mismo mediante la defensa letal del agredido. ${ }^{70 "}$ La utilización de la figura de la autoría mediata parece permitir dar cuenta de inmediato de las razones por las que no hay punibilidad, pese a la ausencia de consideraciones de proporcionalidad. En el caso tratado por Merkel, si el uso de la categoría de la autoría mediata fuera correcto, la muerte del agresor sería constitutiva de suicidio y, por ello, no resultaría punible por causa de la no punibilidad del suicidio. En el derecho chileno, y en general, hispanoamericano, esto es especialmente fácil de ver, desde el momento en que el delito de homicidio es definido no por referencia a un hombre ("el que mate a un hombre"), sino a la muerte de otro. Como el tipo de homicidio no puede realizarse al darse muerte a sí mismo, el homicidio en legítima defensa resultaría atípico. En los casos en que no se trate de la explicación de la falta de punibilidad del homicidio, sino de la realización de otros tipos, la razón de la falta de punibilidad resulta igualmente obvia a partir de esta construcción ${ }^{71}$.

A favor de esta tesis parece hablar, además de su elocuencia y de su capacidad de explicar la ausencia de consideraciones de proporcionalidad ${ }^{72}$, el hecho de que en la dogmática de la

${ }^{70}$ MERKEL, "Folter und Notwehr", cit. nota n 62, pp. 390 y ss.; EL MISMO, “\$ 14 Abs. 3 Luftsicherheitsgesetz: Wann und warum darf der Staat töten?”, Juristen Zeitung 2007, p. 377. En el mismo sentido, y siguiendo a Merkel, JAKOBS, Rechtszwang, cit. nota $\mathrm{n}^{\circ}$ 62, pp. 15 y s.; EL MISMO, System, cit. nota $\mathrm{n}^{\circ}$ 62, pp. 45 y s.; PAWLIK, Unrecht, cit. nota n 62, pp. 237 y s. Similar LESCH, "Die Notwehr", cit. nota $\mathrm{n}^{\circ}$ 9, pp. 91 y ss.; EL MISMO, Notwehrrecht, cit. nota ${ }^{\circ}$ 62, pp. 38-40; MÜSSIG, Bernd, “Antizipierte Notwehr. Das Prinzip der Abwehr rechtswidriger Angriffe als Kriterium objektiver Zurechnung”, Zeitschrift für die gesamte Strafrechtswissenschaft 115 (2003), pp. 232-234; CONINX, Solidaritätsprinzip, cit. nota ${ }^{\circ}$ 62, p. 20; LADIGES, “Erlaubte Tötungen”, cit. nota n 62, p. 880; KRETSCHMER, “Rechtfertigung”, cit. nota $\mathrm{n}^{\circ}$ 62, pp. 178-180. Más lejos BAUMANN/WEBER/MITSCH, AT, cit. nota ${ }^{\circ} 55$, § 17 Nm. 1; EL MISMO, Rechtfertigung, cit. nota $\mathrm{n}^{\circ} 10$, pp. 115 y s.; PUPPE, $A T$, cit. nota $\mathrm{n}^{\circ} 55$, $\S 12$ Nm. 1; LA MISMA, "Rechtfertigung", cit. nota $\mathrm{n}^{\circ}$ 55, pp. 167s. También PALERMO, Legítima defensa, cit. nota $\mathrm{n}^{\circ} 1$, pp. 317 y ss., quien sin embargo considera que se trata sólo de la gestión del derecho del agresor a cumplir con el derecho y no un caso de utilización de un instrumento para autodañarse. El argumento de Palermo, más allá de lo extraño que resulta la idea de que se trata del cumplimiento de un derecho del agresor, parece asumir un concepto de "instrumento" en la autoría mediata que niega la posibilidad de que la transferencia de responsabilidad opere en el nivel de la norma de comportamiento. La dogmática acepta, sin embargo, mayoritariamente esta construcción, con buenas razones. Véase inmediatamente abajo la discusión sobre la autoría mediata mediante un instrumento justificado.

${ }^{71}$ Por cierto, la consecuencia de la aplicación de la figura de la autoría mediata no es justificación, ni siquiera por consentimiento, sino simple atipicidad de la conducta.

${ }^{72}$ No es correcta, a su vez, la crítica de PALERMO, Legítima defensa, cit. nota ${ }^{\circ}$ 1, pp. 321-323, en el sentido de que no podría explicar el carácter facultativo de la legítima defensa -esto es, que su ejercicio no constituya una obligación del agredido-, ni que no puede explicar las reglas sobre exceso (intensivo) en legítima defensa. En lo primero, el argumento es difícilmente comprensible. La autoría mediata no constituye una institución que fundamente obligaciones, sino que transfiere responsabilidad. En ese sentido funciona precisamente como la institución civil que Palermo trae en consideración para demarcarla, a saber, el poder de representación. En lo segundo, la mayor ventaja de la tesis de la autolesión en autoría mediata es precisamente que entrega una justificación a la extensión de la legítima defensa. Esto es evidente en el trabajo de Merkel: el 
autoría mediata tienda a aceptarse la punibilidad del homicidio cometido en legítima defensa, cuando la responsabilidad por la agresión puede atribuirse a un tercero. Ejemplo: A coacciona a B con matar a toda su familia, a menos que B mate a C. Cuando B se dispone a matar a $\mathrm{C}, \mathrm{C}$ reacciona en legítima defensa y mata a $\mathrm{B}$. Además del delito de coacción/amenaza condicional evidentemente imputable a A, la figura de la autoría mediata permite atribuir responsabilidad por el homicidio de B a A, pese a que desde el punto de vista de su autor material, C, se tratara de una conducta justificada ${ }^{73}$. Esta calificación jurídica tiene lugar por la posibilidad de postular que el hecho no es sólo un homicidio justificado, sino también un homicidio del que A es responsable. Pero la posibilidad de postular la corrección jurídica de esta interpretación necesita apoyo en la dogmática de la autoría mediata. Conforme a las premisas de la autoría mediata, puede decirse que el comportamiento de $\mathrm{C}$ es imputable a A si éste es responsable de la realización no punible o no plenamente responsable de un tipo. Si A, por lo mismo, es responsable de que se haya realizado el homicidio (justificado) de $\mathrm{B}$, puede decirse que no se trata de un homicidio justificado, sino de un homicidio prohibido. Uno puede sin demasiados problemas decir que A es responsable del actuar de B -las reglas de estado de necesidad exculpante permiten hacerlo-, y que con ello A es autor mediato del comportamiento de B. Pero la afirmación aquí es que $\mathrm{A}$ es responsable también por el actuar de $\mathrm{C}$ y no sólo de $\mathrm{B}$. Ello parece operar por una doble imputación: $\mathrm{C}$ le transfiere la responsabilidad de su actuar a B por alguna razón, el que se lo transfiere a su vez a A en virtud de la responsabilidad de A por el actuar de B a causa de la aplicabilidad del estado de necesidad exculpante. El razonamiento sólo puede ser completo, sin embargo, si hay transferencia de responsabilidad de $\mathrm{C}$ a B, esto es, si opera doble imputación. Pero si esto es así, entonces parece que la tesis de la autoría mediata en la legítima defensa debe ser verdad: aquí habría autoría mediata de una autoría mediata.

Pese la apariencia de plausibilidad que tienen las dos tesis anteriores, el recurso a la figura de la autoría mediata sólo puede convencer como explicación plástica, y no precisa, de la legítima defensa. Varias razones hablan en contra de ella.

En primer lugar, varios argumentos específicos -cuyo peso ciertamente no es decisivoapuntan en contra de la tesis de la autoría mediata. Ella no parece, por ejemplo, funcionar realmente en casos de legítima defensa de terceros, al menos no sin recurrir a la existencia de una norma permisiva constitutiva de la legítima defensa. Sin la existencia de una norma permisiva, aquello que debiera justificar la transferencia de responsabilidad por la situación al agresor, es la puesta en apuro al agredido (o, siguiendo los estándares del estado de necesidad exculpante, a una persona a él cercana), en el sentido de que el resguardo de

criterio de necesidad se puede construir, bajo esta interpretación, como una determinación de la extensión normativa máxima que alcanza la competencia (responsabilidad) del agresor: sólo en aquello en que la defensa necesaria puede decirse que el agresor carga con responsabilidad por la situación.

${ }^{73}$ Sobre el tratamiento de este caso como homicidio de B por el instrumento C en autoría mediata de A, véase ROXIN, Claus, Strafrecht Allgemeiner Teil. Band II, Múnich: Beck, 2003, § 25 Nm. 50; MAÑALICH, Juan Pablo, "La estructura de la autoría mediata", Revista de Derecho de la Universidad Católica de Valparaíso 34 (2010), pp. 404 y s.; KÖHLER, $A T$, cit. nota n ${ }^{\circ}$ 62, pp. 508 y s.; JAKOBS, $A T$, cit. nota n 62, 21/81ss.; MKJOECKS, § 25 Nm. 74; más lejos SCHÖNKE/SCHÖDER/HEINE/WEISSER, § 25 Nm. 33; NK-SCHILD, § 25 Nm. 84; KÜHL, $A T$, cit. nota ${ }^{\circ} 10, \S 20$ Nm. 59. En contra MATT/RENZIKOWSKI/HAAS, § 25 Nm. 7 , quien también excluye la posibilidad de imputar un comportamiento atípico al hombre de atrás. 
WILENMANN, Javier. "Injusto y agresión en la legítima defensa. Una teoría jurídica de la legítima defensa".

bienes importantes para él requieren lesionar al agresor. Pero esto no sucede cuando es un tercero el que defiende.

En segundo lugar, lo problemático de esta construcción estructural es que, tomada en serio, transforma a la legítima defensa desde su interpretación tradicional de verdadera norma permisiva, a partir de la cual se derivan deberes de tolerancia, a atipicidad por autolesión. Con ello, la legítima defensa no podría verse sujeta a ningún control material, ni siquiera en caso de extrema desproporción: en cualquier caso sería una cuestión penalmente irrelevante.

Mucho más importante que lo anterior es la falta de adecuación de la institución de la autoría mediata a la explicación de la justificación de una conducta. La institución de la autoría mediata no tiene por objeto explicar la permisión de la ejecución de una acción, sino la asunción de responsabilidad pese a la falta de responsabilidad (total o parcial) del instrumento. En ese sentido opera en forma inversa a la legítima defensa: la autoría mediata parte de la verificación de ausencia de responsabilidad por un hecho por parte de su ejecutor y se utiliza para configurar responsabilidad por esa ejecución en el hombre de atrás. En otras palabras: ya que no hay responsabilidad del instrumento por la realización de un tipo -sea por razones prescriptivas o de imputación-, se plantea la pregunta de la posibilidad de atribuir responsabilidad al hombre de atrás por su competencia en la configuración de la situación. Pero en el caso del tratamiento de la legítima defensa como un caso de autoría mediata, ésta es utilizada pragmáticamente a la inversa: se la utiliza para explicar la falta de responsabilidad (por transferencia a otro) y no, en cambio, para explicar punibilidad a partir de la falta de responsabilidad. De esta forma, la tesis de la autoría mediata en legítima defensa parece presuponer lo que debe demostrar. Esto puede producir resultados intuitivamente correctos en algunos casos, pese a la inidoneidad de la institución en cuestión, pero da lugar a resultados contra-intuitivos fuera de los márgenes de los casos más obvios. Si, por ejemplo, un tercero auxilia al agredido a defenderse frente al agresor: ¿debe ser eso calificado como auxilio al suicidio del tercero al agresor ${ }^{74}$ ?

Por supuesto, uno puede presentar el argumento de forma tal que éste no presuponga lo que debe demostrar, esto es, que la estructura de la autoría mediata permita directamente explicar los casos de legítima defensa. Si se trata de un simple caso de autoría mediata, la imputación del comportamiento del instrumento como si fuera comportamiento del hombre de atrás necesita, en una comprensión jurídica de la autoría mediata, una razón que permita el desplazamiento de responsabilidad por el comportamiento. Como la legítima defensa no es una institución autónoma por definición bajo esta institución, ella no puede servir para justificar el desplazamiento. Ello quiere decir que para que la imputación de que la muerte del agresor sea, en realidad, el resultado de una acción suya (ejecutada a través del agredido), uno debe encontrar un argumento jurídico en el que apoyarse para permitir la imputación en cuestión. Sin recurso a una norma permisiva - ya que la tesis de la autoría mediata afirma que, en realidad, no hay tal caso, sino imputación del comportamiento del agredido como comportamiento del agresor -ese desplazamiento tiene que ser explicado por otra institución. En consideración viene ante todo el estado de necesidad exculpante (o, en la versión más bien hispánica, la fuerza psicológica que ejerce la situación sobre el

\footnotetext{
${ }^{74}$ Correctamente MAÑALICH, "Normas permisivas", cit. nota n 62, p. 490, nota 81.
} 
agredido- miedo o fuerza insuperable). Si esto es así, entonces la transferencia de responsabilidad sólo puede operar si la situación puede ser vista, al mismo tiempo, como un estado de necesidad exculpante del agredido provocado responsablemente por el agresor. Pero el estado de necesidad exculpante limita su procedencia precisamente a la afectación de bienes graves. En el derecho alemán, se excluye en el $\S 35 \mathrm{StGB}$ a la propiedad, por ejemplo, como bien cuya amenaza de lesión puede dar lugar a un estado de necesidad exculpante. En el derecho chileno, en el que en el año 2010 se reconoció positivamente el estado de necesidad exculpante, el artículo 10 número 11 del Código Penal limita su procedencia a que se trate de evitar un "mal grave". Ello implica que la idea de autoría mediata precisamente no funciona en la institución conflictiva que la tesis pretende explicar -la posibilidad de matar o herir gravemente en defensa de bienes patrimoniales-, ya que en esa situación no es posible recurrir al estado de necesidad exculpante para explicar la transferencia de responsabilidad, y con ello a ninguna otra institución que permita explicar jurídicamente el traspaso de responsabilidad por el actuar del agredido hacia el agresor.

En otros términos: contra lo que la tesis supone, ella parece reducir a la legítima defensa a la forma que tenía antes de su reestructuración decimonónica, como reconocimiento del poder de legitimación que se deriva de la necesidad de autoconservación ${ }^{75}$. Y esta imposibilidad se da precisamente por no asumir la explicación teóricamente más sencilla, a saber, que la legítima defensa constituye un verdadero permiso. Con ello, la tesis de la autoría mediata efectivamente o bien supone lo que ella necesita demostrar, o bien presenta una explicación a la estructura de la legítima defensa que es incompatible con su estructura en el derecho vigente.

Concedido: el argumento anterior no es una demostración de incompatibilidad lógica, en el sentido de que la tesis no pueda funcionar del todo. Para operar como argumento lógico, la autoría mediata necesitaría construirse sobre puras reglas de imputación y no admitir que ella tenga relevancia en la determinación del sentido del hecho conforme a normas de comportamiento. Pero la autoría mediata tiene una función propiamente constitutiva de la interpretación normativa del comportamiento en los casos de autolesión (fáctica) del instrumento, en los que se acepta de forma absolutamente predominante la postulación de punibilidad por autoría mediata ${ }^{76}$. Ejemplo: A amenaza con matar al hijo de B a menos que éste le permita extraerle el riñón ${ }^{77}$. Sin recurso a la autoría mediata, el comportamiento sólo podría ser considerado como una verdadera autolesión, por lo que en principio se trataría de una conducta penalmente irrelevante. La autoría mediata precisamente permite en ese caso recalificarla como una conducta de responsabilidad del hombre de atrás y, con ello, como

\footnotetext{
${ }^{75}$ Sobre la evolución de la legítima defensa en este sentido ya BERNER, Nothwehrtheorie, cit. nota $\mathrm{n}^{\circ} 21$, 549s. Sobre el vínculo entre justificación de la legítima defensa en auto-conservación y su interpretación como "obligación de defenderse", HRUSCHKA, "Kants Rechtslehre", cit. nota n 59, p. 209. Sobre la conexión entre legítima defensa y autoconservación, véase también, con ulteriores referencias, LUZÓN PEÑA, Aspectos esenciales, cit. nota n ${ }^{\circ} 2$, pp. 28 y ss.

${ }^{76}$ BGHSt 43, 177; JAKOBS, AT, cit. nota n ${ }^{\circ} 62,21 / 97 \mathrm{ss}$.; ROXIN, AT II, cit. nota $\mathrm{n}^{\circ} 73, \S 25 \mathrm{Nm} .54 \mathrm{ss} ., 70$, 74-75; MATT/RENZIKOWSKI/HAAS, § 25 Nm. 37ss.; MK-JOECKS, § 25 Nm. 63ss.; NK-SCHILD, § 25 Nm. 85.

${ }^{77}$ En $B G H S t$ 43, 177, se trataba de una trampa dejada en una casa a unos individuos, que anteriormente habían irrumpido en la casa y consumido alimentos y bebidas, al dejar en una botella etiquetada como una bebida alcohólica un líquido que en caso de ser bebido sería mortal.
} 
WILENMANN, Javier. "Injusto y agresión en la legítima defensa. Una teoría jurídica de la legítima defensa".

una acción que cumple del todo con ser de la clase de conductas típicas - en este caso lesión gravísima. Es importante tener en cuenta, sin embargo, que la estructura del argumento de la legítima defensa como autoría mediata es exactamente la inversa que la estructura del argumento de la autoría mediata en una autolesión. Mientras en el caso de la autolesión, la invocación a la autoría mediata derrota la interpretación del comportamiento como auto-lesión y hace que sea vista como una heterolesión -la fenomenología del hecho se demuestra, así, como falsa-, en el caso de la legítima defensa, la invocación de la autoría mediata sirve para calificar a la conducta como un verdadero caso (normativamente considerado) de autolesión del instrumento cuando, en su fenomenología, parece ser un caso de heterolesión. Este cambio de sentido interpretativo explicaría la no punibilidad. Pero esto produce todos los problemas insuperables que han sido explicados en los párrafos anteriores.

Esto muestra que, en el caso planteado más arriba de autoría mediata por actuación a través de un instrumento justificado, no hay doble imputación sucesiva que explique la autoría mediata de $\mathrm{A}$ en el homicidio de $\mathrm{B}$, sino que una imputación directa - sin pasar por B- de la acción de C a A. Esta es, por lo demás, la forma en que la dogmática parece en general comprenderlo: lo denomina precisamente "actuación a través de un instrumento justificado" y no, en cambio, doble imputación por autoría mediata de autoría mediata. Como siempre, el camino más sencillo es más verosímil y permite evitar deformaciones.

\subsubsection{La tesis de la asunción de riesgo o del consentimiento del agresor en la lesión.}

La fundamentación de la legítima defensa en la responsabilidad del agresor ha intentado ser explicada a su vez, de forma todavía más conflictiva, a través del recurso a las figuras del consentimiento en la lesión o, en los términos de la comprensión dominante de la imputación objetiva, a la interrupción del vínculo entre acción y resultado por asunción del riesgo por parte de la víctima. ${ }^{78} \mathrm{Al}$ igual que en el caso de la tesis de la autoría mediata, la idea de que uno pueda decir que el autor es quien debe ser considerado responsable de la situación, que se encuentra detrás de estas situaciones, es ciertamente correcta. El problema de la reconstrucción de la legítima defensa a través de otras categorías de la teoría del hecho punible, sin embargo, es que al igual que la tesis de la autoría mediata, su utilización directa deforma a la institución en cuestión. A esta tesis le atraviesan dos clases de problemas: problemas indirectos, que demuestran inconsistencias sistemáticas de las instituciones que son tomadas para explicar la legítima defensa (ante todo: la imputación objetiva); y problemas directos relativos a la incapacidad de las figuras utilizadas para explicar correctamente la extensión de la legítima defensa.

La primera clase de problemas es especialmente clara en la tesis de Christian Jäger, la que demuestra además los problemas vinculados a la comprensión dominante de la imputación objetiva $^{79}$. De acuerdo a Jäger, la legítima defensa podría ser reconstruida no como causa

\footnotetext{
${ }^{78}$ En este sentido MONTENBRUCK, Axel, Thesen zur Notwehr, Heidelberg: C.F. Müller, 1983, pp. 33-37; y JÄGER, Zurechnung, cit. nota n ${ }^{\circ}$ 62, pp. 31-33. Similar ya BELING, Ernst, Grundzüge des Strafrechts, $11^{\mathrm{a}}$ Edición, Tubinga: Mohr, 1930, p. 16.

${ }^{79}$ Véase a este respecto con más detalle WILENMANN, Javier, "Injusto, justificación e imputación", en: MAÑALICH (Coord.), La antijuridicidad en el Derecho penal, Montevideo/Buenos Aires, BdeF, 2013, pp. 156-161.
} 


\section{Polít. crim. Vol. 10, No 20 (Diciembre 2015), Art. 7, pp. 622-677. \\ [http://www.politicacriminal.cl/Vol_10/n_20/Vol10N20A7.pdf]}

de justificación, sino como una causa de exclusión de la imputación (objetiva) que, como tal, eliminaría la tipicidad en la construcción mayoritaria del hecho punible ${ }^{80}$. La razón por la que sería posible postular que la legítima defensa es una causa de exclusión de la imputación, sería precisamente la afirmación de que el agresor carga con toda la responsabilidad por la necesidad de defenderse. Esto, por cierto, reproduce correctamente el fundamento de la legítima defensa, pero Jäger lo tematiza como causa de exclusión del injusto para evitar lo que éste denomina "contradicciones valorativas" dadas por el hecho de que la atipicidad es una calificación más favorable que la justificación ${ }^{81}$.

$\mathrm{Su}$ reconstrucción de la legítima defensa se inserta así en un intento de "solucionar" los problemas sistemáticos que aquejan a una teoría del hecho punible que recoge ampliamente la categoría de la imputación objetiva. Jäger pretende solucionar las contradicciones sistemáticas que se siguen del dogma "interrupción de la imputación (objetiva) es mejor que justificación" 82 a partir de un criterio material: Toda causa de no punibilidad que implique no afirmación de responsabilidad por el resultado es una causa de interrupción de la imputación, mientras que la permisión por causa de "ponderación de intereses" - esto muestra la forma en que Jäger también se encuentra parado sobre la teoría del interés preponderante, aunque con razón excluye a la legítima defensa por completo de cualquier vínculo con ésta- implica (sólo) justificación. Esta solución tiene consecuencias sistemáticas profundas: la legítima defensa integraría un mismo nivel que el consentimiento

\footnotetext{
${ }^{80} \mathrm{JÄGER}$, Zurechnung, cit. nota ${ }^{\circ} 62$, pp. 31 y s.

${ }^{81} \mathrm{JÄGER}$, Zurechnung, cit. nota $\mathrm{n}^{\circ} 62$, pp. 9 y ss. Como la construcción paulatina del juicio de merecimiento de pena implica que la afirmación del estadio anterior deja al comportamiento en un peor estado valorativo que aquel que se seguiría de no cumplirse con ese juicio -expresado plásticamente: la opinión dominante sigue el dogma de Welzel, respecto a que un comportamiento atípico es mejor que un comportamiento típico pero no antijurídico-, la calificación de un comportamiento como "no imputable" (objetiva o subjetivamente) parece implicar un privilegio respecto de la calificación "justificado". Esto genera de entrada un dilema sistemático que ha sido frecuentemente criticado a la opinión dominante: las figuras de exclusión de la imputación (sobre todo objetiva) parecen ser figuras privilegiantes frente a las causas de justificación, sin que ello sea del todo justificable. El caso más dramático es el de la relación entre la exclusión de la imputación objetiva por aceptación del peligro creado por otro, frente al verdadero consentimiento del ofendido, si se lo conceptualiza - como mayoritariamente se hace en Alemania- como causa de justificación. La contradicción sistemática de ese caso es evidente las figuras de exclusión de la imputación (sobre todo objetiva) parecen ser figuras privilegiantes frente a las causas de justificación, sin que ello sea del todo justificable. El caso más dramático es el de la relación entre la exclusión de la imputación objetiva por aceptación del peligro creado por otro, frente al verdadero consentimiento del ofendido, si se lo conceptualiza -como mayoritariamente se hace en Alemania- como causa de justificación. La contradicción sistemática de ese caso es evidente: el consentimiento en la puesta en peligro no implica consentimiento en la lesión, por lo que pese a que el consentimiento del ofendido vaya más lejos, sería valorativamente menos relevante. Esto es, sin embargo, un mero problema sistemático interno de una construcción sistemática que desde sus inicios es problemática. La mera negación de la imputación implica sólo cierre a la calificación normativa de la acción en relación con las reglas de imputación que correspondan, cuyo objeto en este caso es sólo afirmar el merecimiento de pena. Ellas no pueden tener analíticamente ningún sustento normativo positivo: no es más que una simple negación. La atribución de un status distinto, dado por la mezcla de la teoría dominante de comprensión del vínculo entre tipicidad e imputación con la teoría de la imputación objetiva, sólo puede corresponder a un arreglo sistemático equivocado.

${ }^{82}$ El error categorial de esta afirmación es demostrado en WILENMANN, "Injusto”, cit. nota n 79, pp. 156 y Ss.
} 
WILENMANN, Javier. "Injusto y agresión en la legítima defensa. Una teoría jurídica de la legítima defensa".

y las distintas formas de interrupción de la imputación objetiva, mientras el estado de necesidad integraría un segundo nivel distinguible de éste ${ }^{83}$.

Una construcción de esta clase se encuentra expuesta a todas las críticas que afectan al dogma de la "distinta valoración" de tipicidad y antijuridicidad a la categoría de la imputación objetiva en su comprensión dominante, y a la teoría del interés preponderante. Pero sus problemas son mucho más profundos que esto. La construcción de Jäger manifiesta la mayor inflación posible de la imputación objetiva. En los hechos, ella convierte a las instituciones fundamentales del consentimiento y de la legítima defensa, en meros problemas de imputación objetiva, esto es, en reglas de atribución de responsabilidad. Esto no sólo crea problemas en la fundamentación normológica de los deberes de tolerancia, sino que hace que los problemas que vimos a propósito de la construcción de la autoría mediata se reproduzcan aquí, aunque con la salvedad que al tratarse de una institución que no opera con reglas verdaderamente formales de distribución -la teoría de la imputación objetiva-, la cuestión sea mucho más indeterminada. Dicho de otra forma: las contradicciones valorativas internas en la teoría del hecho punible que incluye una categoría tan intensa de la imputación objetiva sólo pueden ser naturales: una categoría con potencial de expansión a todo problema de la Parte General sólo puede disputar el ámbito de aplicabilidad de las instituciones que le precedían. Las contradicciones valorativas se producen, por ello, antes por la construcción sin límites de la imputación objetiva que por problemas en la teoría del consentimiento o de la legítima defensa.

Pero los problemas que aquejan a esta construcción no son, como hemos visto, sólo "indirectos", en el sentido de ser expresivos de problemas sistemáticos originados a partir de otras instituciones. La idea de asunción de riesgo o consentimiento tampoco permite explicar la extensión de la legítima. El recurso al consentimiento precisamente no funciona en el caso más grave que se trata de explicar, a saber, el homicidio en legítima defensa. Los sistemas jurídicos tienen reglas como la punibilidad del homicidio a petición ( $\$ 216 \mathrm{StGB}$, artículo 143 número 4 del Código Penal español) o la punibilidad de la inducción o del auxilio al suicidio (artículo 393 del Código Penal chileno, 143 del Código Penal español) que mantienen, aunque en algunos casos con privilegios en la pena, la punibilidad del homicidio consentido. Si ello tiene lugar en casos en que hay incluso consentimiento serio y expreso, en situaciones de sufrimiento del que quiere morir, ¿por qué habría de tener efecto justificante en un caso en que hay una simple construcción de un consentimiento concluyente en la muerte del agresor, la que tiene lugar contra la voluntad que uno puede asumir es subjetivamente real?

El argumento es tan obvio, que la dogmática se cuida de tratar esta forma de consentimiento como un consentimiento en la actividad riesgosa, una asunción de riesgo en la nomenclatura de Montenbruck. Después de todo, la imputación al ámbito de responsabilidad de la víctima también operaría en el delito de homicidio. Pero esto es sólo una argumentación elusiva. Imputación al ámbito de responsabilidad de la víctima implica la interpretación de la relación entre autor y víctima como participación conjunta en una actividad riesgosa, no como una acción cuyo sentido directo es causar la lesión (y en su

${ }^{83}$ JÄGER, Zurechnung, cit. nota n ${ }^{\circ} 62$, pp. 21 y ss. 
caso muerte) de la víctima. Si este es el sentido de la acción del autor, la única institución que puede venir en consideración es el consentimiento. Pero éste no tiene potencial explicativo directo de la justificación (o atipicidad, la etiqueta no es demasiado relevante para estos efectos) del homicidio.

Por supuesto, al igual que en el caso de la tesis de la autoría mediata, esta forma de comprender la legítima defensa funciona si ella, en realidad, presupone lo que debiera demostrar, a saber, la existencia de una norma permisiva independiente de las normas relativas a asunciones de peligro o del consentimiento. Uno puede así decir sin error que hay un consentimiento concluyente del agresor en la lesión, ya que al haber gatillado de forma plenamente imputable una consecuencia jurídica de esta clase, puede decirse que consintió en la aplicación de la consecuencia en cuestión. La construcción del consentimiento aparece aquí fundamentada en relación con dos hechos: la existencia de la institución de la legítima defensa y el ejercicio de la agresión como producción plenamente imputable de una situación en que procede esa consecuencia jurídica. Como el permiso de lesión en situación de legítima defensa existe, uno consentiría en la lesión al producir las condiciones de procedencia de la legítima defensa (la agresión intencional). La construcción no es, por cierto, incorrecta, pero no da cuenta de ninguna particularidad de la legítima defensa: todas las instituciones jurídicas que requieren alguna atribución de intencionalidad se dejan fundamentar de igual forma por este medio. Esto es algo trivialmente conocido en general en el derecho desde Rousseau y trivialmente conocido en la teoría de la pena desde Hegel. Por ello, fundamentar la legítima defensa en un consentimiento concluyente en ella al modelo en que Hegel utiliza la figura para fundamentar la pena ${ }^{84}$, no es más que la expresión de que lo que justifica la legítima defensa son reglas de imputación en algún sentido asimilables a aquellas del hecho punible.

1.2.5. La idea de plena responsabilidad por la infracción de autonomía formal ajena y la figura de la asunción.

La tesis de la autoría mediata y la tesis del consentimiento no pueden, de esta forma, ser comprendidas como teorías que sean defendibles si se las interpreta literalmente. Ellas pretenden, sin embargo, servir como descripción metafórica del fundamento de la legítima defensa, al expresar las razones por las que el derecho hace plenamente responsable al agresor por las consecuencias que se siguen de la necesidad de defenderse: al igual que en la autoría mediata, el agresor carga con la responsabilidad del comportamiento del agredido. Esto no es, sin embargo, una aplicación de reglas de auto-puesta en peligro o de autoría mediata. Se trata simplemente de un caso normal de asunción de consecuencias jurídicas por desconocer de forma plenamente imputable las reglas; esto es precisamente aquello que hace que, en un sistema normativo construido sobre categorías de responsabilidad, la legítima defensa aparezca como una institución jurídicamente necesaria.

\footnotetext{
${ }^{84}$ Este es el argumento que de forma conocida se encuentra en el $\S 100$ de los Principios de la Filosofía del Derecho de Hegel. Véase HEGEL, Georg Willhelm Friedrich, Grundlinien der Philosophie des Rechts, Werke 7, Fráncfort del Meno: Suhrkamp, 1986, pp. 190-192. Al respecto, véase también SEELMANN, Kurt, "Person, Norm", en: PAWLIK y ZACZYK (Eds.), Festschrift für Günther Jakobs, Colonia/Berlín/Múnich: De Gruyter, 2007, pp. 636 y s.
} 
WILENMANN, Javier. "Injusto y agresión en la legítima defensa. Una teoría jurídica de la legítima defensa".

Desde el punto de vista el agredido, la legítima defensa se justifica, de esta forma, en el desconocimiento de su posición ${ }^{85}$. Desde el punto de vista del agresor, la legítima defensa y su particular rigor se justifican, al igual que la pena conforme a la teoría de la imputación, en que el desconocimiento de las prohibiciones correspondientes es verificado mediante reglas especiales de imputación que permiten atribuir plena responsabilidad. La legítima defensa se fundamenta, de esta forma, en el hecho de que el agresor ha desconocido los derechos del agredido, al infringir de forma plenamente responsable las prohibiciones establecidas por el derecho penal para su protección, y que esta plena responsabilidad permite utilizar la figura de la asunción para justificar la extensión de la legítima defensa ${ }^{86}$.

En otras palabras: distribución de autonomía y mantenimiento de esa distribución a partir de normas cuya defraudación se verifica intencionalmente reproducen los problemas tradicionales del concepto de responsabilidad, y nada más. La legítima defensa se inserta en este esquema. Ella es una forma de mantenimiento de autonomía formal derivada de un concepto de responsabilidad fuerte que es inmanente al derecho penal moderno: el permiso de afectación de intereses encuentra su fundamento en la propia responsabilidad del autor por haber creado intencionalmente el estado de cosas antinormativo que hace necesaria la defensa para evitar su concreción. Como tal, tiene una dependencia de formas de atribución de intencionalidad del comportamiento que encuentran expresión en la utilización en la mayor parte del derecho penal de un concepto tradicional de las normas y de la acción. Esto es precisamente lo que hace que sea sustantivamente aplicable el modelo de fundamentación de la asunción: el agresor asume (o, en sentido metafórico, consiente concluyentemente en) la lesión que deriva de la defensa, porque el derecho puede legítimamente entregarle este sentido ${ }^{87}$. En sus detalles, esto permite justificar tanto la obligación de no ceder -recuérdese la reconstrucción hegeliana de la pragmática de la relación entre agresor y agredido; si hay obligación de ceder, entonces la prohibición de afectación no es real y, por lo mismo, el derecho asegurado tampoco- como la no inclusión de criterios de proporcionalidad (más allá, como veremos, de la extrema desproporción).

Este es el contexto en el cual se inserta la polémica incorrectamente referida a la exigencia de culpabilidad en la legítima defensa ${ }^{88}$. Si la distinción entre legítima defensa y estado de

\footnotetext{
${ }^{85}$ Fundamental, como hemos visto, BERNER, Nothwehrtheorie, cit. nota $\mathrm{n}^{\circ} 21$, pp. 553 y ss.; y EL MISMO, Lehrbuch des deutschen Strafrechts, 6 ${ }^{\mathrm{a}}$ Edición, Leizpig: Tauchnitz, 1872, p. 145; y HÄLSCHNER, Strafrecht 2, cit. nota $\mathrm{n}^{\circ} 59$, pp. 253 y ss.

${ }^{86}$ En el mismo sentido NK-KINDHÄUSER, $§ 32$ Nm. 22-24. Véanse también las citas en la nota a pie de página siguiente respecto a la exigencia de "culpabilidad" de la agresión. La defensa de esta tesis tiene lugar precisamente por el postulado de una teoría del fundamento de la legítima defensa de esta clase.

${ }^{87}$ Como hemos visto, la figura de la asunción es utilizada directamente por los hegelianos Michelet y Abegg, y ella subyace a su vez a la argumentación fundamental de Berner y de Hälschner, centrada antes en la justificación de la no necesidad de ceder y en la posición del agredido. Ambos aspectos, sin embargo, se corresponden.

${ }^{88}$ En la literatura contemporánea JAKOBS, AT, cit. nota $\mathrm{n}^{\circ} 62,12 / 16-21$; PAWLIK, Notstand, cit nota $\mathrm{n}^{\circ} 9$, pp. 307 y s. (crítico, sin embargo, en EL MISMO, Unrecht, cit. nota n ${ }^{\circ} 62$, pp. 241 y 268, nota 76); HAAS, Notwehr, cit. nota $\mathrm{n}^{\circ} 1$, pp. 223 y ss.; HRUSCHKA, $A T$, cit. nota $\mathrm{n}^{\circ}$ 62, pp. 141 y ss.; EL MISMO, "Rechtsfertigungsgründe", cit. nota n 62, p. 206; RENZIKOWSKI, Notstand, cit. nota n 19, p. 99; EUE, "Anmerkung", cit. nota $\mathrm{n}^{\circ}$ 62, p. 766; FREUND, AT, cit. nota $\mathrm{n}^{\circ}$ 62, Nm. 98; MÜSSIG, "Antizipierte Notwehr", cit. nota $\mathrm{n}^{\circ}$ 62, p. 233 nota 34; LESCH, Notwehrrecht, cit. nota $\mathrm{n}^{\circ}$ 62, pp. 40 y s.; EL MISMO, "Die Notwehr", cit. nota n 9, pp. 94 y ss.; LUDWIG, Angriff, cit. nota n 10, pp. 106 y s.; GRÜNEWALD,
} 


\section{Polít. crim. Vol. 10, № 20 (Diciembre 2015), Art. 7, pp. 622-677. \\ [http://www.politicacriminal.cl/Vol_10/n_20/Vol10N20A7.pdf]}

necesidad defensivo tiene alguna justificación sistemática, y si además la medida de la extensión de la facultad de defensa en legítima defensa puede ser fundamentada de forma convincente, ello sólo puede tener lugar en relación con un concepto de responsabilidad fuerte. Pero responsabilidad fuerte implica asumir el modelo de la acción: construir condiciones de interpretación de un comportamiento como no seguimiento exigible de la norma. La dogmática de la legítima defensa tematiza las reglas de imputación que permiten esa atribución de responsabilidad fuerte. El tratamiento de esas reglas de imputación forma parte, con ello, de la dogmática particular de ésta. Aquí sólo es necesario insistir en un punto: responsabilidad normativa fuerte no se deja entender sin exigencia de plena competencia normativa, es decir, sin que exista la posibilidad del todo de entender que el sujeto (construido aquí en relación con su voluntad) se comportó contra las exigencias normativas. La construcción del sujeto presupone, por ello, capacidad de comprensión y seguimiento racional de normas y atribución de conocimiento del contenido de las normas.

Considerada desde el punto de vista de sus fundamentos, la legítima defensa es, de esta forma, la respuesta necesaria a la afectación injusta de intereses protegidos o, lo que es lo mismo, de una agresión por desconocimiento plenamente responsable de la prohibición de afectación o del mandato de resguardo respectivo. La dogmática de la legítima defensa tiene por objeto determinar las condiciones formales generales, a partir de los conceptos utilizados por el derecho positivo, para el reconocimiento de una agresión, así como los límites de la facultad de defenderse en legítima defensa.

Anette, Das vorsätzliche Tötungsdelikt, Tubinga: Mohr-Siebeck, 2010, pp. 231 y s.; ENGLÄNDER, Nothilfe, cit. nota $\mathrm{n}^{\circ} 10$, pp. 256-258; FRISTER, "Notwehr", cit. nota $\mathrm{n}^{\circ}$ 55, pp. 305 y ss.; NK-KINDHÄUSER, $§ 32$ Nm. 22-23 y 65; EL MISMO, "Unrecht”, cit. nota n 2, pp. 506 y s.; KORIATH, Heinz, "Das Brett des Karneades", Juristische Arbeitsblätter 1998, pp. 253 y s.; KROß, Notwehr, cit. nota $\mathrm{n}^{\circ}$ 10, p. 64; SCHMIDHÄUSER, $A T$, cit. nota ${ }^{\circ}$ n. 12, 9/86; HOYER, "Rechtsinstitut", cit. nota n 62, pp. 95 y ss. (no así en EL MISMO, Strafrechtsdogmatik, cit. nota ${ }^{\circ} 34$, pp. 211 y s.); SENGBUSCH, Subsidiarität, cit. nota ${ }^{\circ}$ 62, p. 148; ZIMMERMANN, Rettungstötungen, cit. nota ${ }^{\circ}$ 62, pp. 163 y s.; BALDÓ LAVILLA, Estado de necesidad, cit. nota $\mathrm{n}^{\circ}$ 62, p. 60; PALERMO, Legítima defensa, cit. nota $\mathrm{n}^{\circ} 1$, pp. 289 y s.; MAÑLICH, "Normas permisivas", cit. nota n ${ }^{\circ}$ 62, p. 514 nota 186; WILENMANN, Freiheitsdistribution, cit. nota $n^{\circ} 50$, pp. 181 y s. con nota 93. De lege ferenda también FRISTER, $A T$, cit. nota $\mathrm{n}^{\circ}$ 58, 16/11s. Por cierto, la polémica respecto a la exigencia de "culpabilidad" en la acción antijurídica en la legítima defensa es confusa en su terminología, como correctamente muestran LESCH, Notwehrrecht, cit. nota ${ }^{\circ}$ 62, p. 18; EL MISMO, "Die Notwehr", cit. nota n 9, pp. 94 y ss.; NK-KINDHÄUSER, § 32 Nm. 66; EL MISMO, Strafgesetzbuch. Lehr- und Praxiskommentar, 5 ${ }^{\mathrm{a}}$ Edición, Baden-Baden: Nomos, 2013, § 32 Nm. 25-26: MAÑALICH, "Normas permisivas", cit. nota n ${ }^{\circ}$ 62, p. 514 nota 186; y WILENMANN, Freiheitsdistribution, cit. nota ${ }^{\circ} 50$, pp. 181 y s. con nota 93. Culpabilidad en sentido estricto solo puede tener lugar en relación con acciones típicas, lo que en ningún caso es defendido por los representantes de la opinión que exige "culpabilidad" del agresor. Culpabilidad es además una cailficación de responsabilidad personal cuyo objeto de referencia es la pena, lo que no tiene conexión con la legítima defensa. En cambio, se trata de la exigencia de criterios personales fuertes de imputación (es decir, capacidad de apelación normativa). Correctamente remarca por ello LESCH, Notwehrrecht, cit. nota ${ }^{\circ}$ 62, pp. 40 y s., que la "culpabilidad" en el contexto de la legítima defensa no corresponde ni puede corresponder a la culpabilidad en el contexto de la teoría del hecho punible. Se trata, en cambio, de una interpretación de las reglas de imputación en la legítima defensa que incorporen criterios de responsabilidad fuerte en relación con la constitución del sujeto. Como se trata del concepto de culpabilidad de la teoría del delito, los argumentos tradicionales que se entregan contra esta opinión (en el sentido de que el derecho positivo exige "antijuridicidad" de la agresión y no culpabilidad) no tienen ningún peso. 
WILENMANN, Javier. "Injusto y agresión en la legítima defensa. Una teoría jurídica de la legítima defensa".

La estructura de la legítima defensa es, de esta forma, una formalización jurídicamente operativa de las condiciones de legitimidad de la facultad fuerte de defensa de una posición agredida. Estos requisitos deben determinar, por ello, las condiciones que desde el punto de vista del agresor y del agredido deben cumplirse para reconocer una agresión plenamente responsable, así como los límites de la defensa en una situación de esta clase. Por supuesto, una descripción de esta clase del sentido de la determinación del contenido de ciertas reglas también puede ser efectuada en otro ámbito, a saber, el de la teoría del hecho punible. En particular, la idea de imputación en la teoría del hecho punible también puede ser presentada como una operativización de reglas de responsabilidad fuerte en la atribución del sentido de vulneración de normas subyacentes a tipos. La relativa coincidencia de sentido entre ambas clases de sistemas normativos ha tendido a sugerir, por ello, interpretar las mucho más específicas y limitadas reglas de la legítima defensa a partir de las reglas de imputación de la teoría del hecho punible. El hilo de Ariadna podría ser, con ello, encontrado sistemáticamente. En lo que sigue, nos interesa revisar esta sugerencia sistemática, de forma tal de determinar su potencial de rendimiento como base de una dogmática de la legítima defensa.

\section{La posición sistemática de la agresión ilegítima y sus consecuencias en la dogmática de la legítima defensa.}

\subsection{Introducción: la tesis de la inserción sistemática.}

Pese a que el concepto que tiende a ser utilizado entre nosotros para designar a la agresión que constituye una situación de legítima defensa -la agresión ilegítima - sugiera menos directamente establecer un vínculo sistemático con la teoría general del hecho punible que el concepto del derecho penal alemán ${ }^{89}$-la agresión antijurídica del inciso segundo del párrafo 32 StGB- ${ }^{90}$, existe una tendencia natural a intentar dar una interpretación de esta institución que encuentre algún reflejo en alguno de los conceptos que se utilizan al tratar el hecho punible, esto es, la sugerencia de que se trata de un concepto sistemático que se reproduce enteramente en otros ámbitos se encuentra en el origen de las dificultades ligadas al concepto de agresión en legítima defensa". La expresión "agresión antijurídica" podría ser así entendida como sinónimo de "injusto", el que a su vez es utilizado, en sentido amplio, como sinónimo de hecho punible o de una parte de sus condiciones de reconocimiento (al menos cuando se habla de un injusto penal). Después de todo si las amplias facultades de defensa, con controles absolutamente mínimos de proporcionalidad material y sin imposición de obligaciones de ceder, se justifica en la idea de que "el derecho no debe ceder ante el injusto" $" 92$, puede parecer a primera vista razonable reconocer

\footnotetext{
${ }^{89}$ En español la idea de la inserción sistemática es sostenida, sin embargo, por LUZÓN PEÑA, Lecciones, cit. nota $\mathrm{n}^{\circ} 29,23 / 19$.

${ }^{90}$ Sería ciertamente equivocado deducir de la utilización de distintos adjetivos una voluntad política de diferenciación en uno u otro ordenamiento jurídico. El concepto de antijuridicidad es un germanismo cuya utilización general en idioma español se remonta apenas al siglo XX. Siendo que la utilización del concepto de agresión ilegítima se remonta al Código Penal español de 1848, la utilización de un adjetivo como "ilegítimo" no expresa nada distinto de lo que hace el concepto alemán.

${ }^{91}$ Así también ENGLÄNDER, Nothilfe, cit. nota ${ }^{\circ} 10$, pp. 234 y s.

${ }^{92}$ BERNER, Lehrbuch, cit. nota $\mathrm{n}^{\circ}$ 75, p. 145; EL MISMO, Notwehrtheorie, cit. nota ${ }^{\circ}$ 21, p. 562. La fórmula de Berner (Das Recht braucht dem Unrecht nicht zu weichen) constituye un aforismo omnipresente
} 
un concepto unitario de injusto en el ámbito de la teoría de la legítima defensa y en el ámbito de la teoría del hecho punible. Explicado en términos estructurales: ya que la teoría del hecho punible presenta un esquema de interpretación del comportamiento como vulneración de normas o como puesta en peligro reprochable de bienes jurídicos, utilizar ese esquema de interpretación puede parecer sistemáticamente necesario. La agresión antijurídica o ilegítima debiera representar, de esta forma, un injusto en los términos en que esto es comprendido en la teoría del hecho punible. Esto puede ser denominado la tesis de la inserción sistemática de la agresión antijurídica en la teoría del hecho punible.

La tesis de la inserción sistemática se deja exponer en distintas variantes, dependiendo del tipo de concepto de injusto que se reconozca. Para quien, como era tradicional, desconozca la existencia de un injusto puramente objetivo, la tesis de la inserción sistemática presenta consecuencias distintas que para quien defiende un concepto de injusto desligado de consideraciones de atribución de culpabilidad. En lo que sigue, nos interesa revisar la plausibilidad de la tesis de la inserción sistemática en sus dos variantes. Como veremos, los resultados a los que conduce en ambos casos demuestran la falsedad de la tesis. Una dogmática de la legítima defensa debe orientarse al desarrollo de criterios autónomos de imputación.

\subsection{La tesis de la inserción sistemática en una teoría estricta del injusto: Merkel y Binding.}

Pese a que la forma en que la tesis de la inserción sistemática es defendida hoy en día se vincule, como veremos, a la distinción à la Mezger entre injusto y culpabilidad, la misma pretensión puede encontrarse entre ciertos partidarios de un concepto estricto de injusto como vulneración responsable de normas de comportamiento ${ }^{93}$. En la dogmática de la segunda mitad del siglo XIX y de principios del siglo XX, la discusión respecto a la tesis de la integración sistemática de la agresión antijurídica tendía a relacionarse con dos polémicas cruciales en la historia de la ciencia penal que se encuentran vinculadas entre sí: la posibilidad de reconocer un injusto objetivo ${ }^{94}$ y el denominado problema del destinatario en la teoría de las normas. La forma en que ambos problemas, cuyo objeto directo de referencia era la caracterización del injusto penal o del alcance de las normas y no el tratamiento del concepto de agresión en legítima defensa, afectaba sin embargo a éste, puede ser fácilmente explicada.

\footnotetext{
en la cultura jurídica alemana, recogido por la jurisprudencia en RG 55, 85, cuyo peso cultural puede ser fácilmente sobreestimado desde afuera.

${ }^{93}$ En lo que tal vez sea un lenguaje más familiar en Español, esto implica la defensa de la tesis de que jurídicamente sólo existe (en una forma además calificada) "antijuridicidad formal”. Sobre la distinción véase el conocido estudio de MÓLINA FERNÁNDEZ, Antijuridicidad, cit. nota n ${ }^{\circ} 7$, pp. 45 y ss.

${ }^{94} \mathrm{Al}$ respecto ilustrativos PAWLIK, "Der wichtigste dogmatische Fortschritt der letzten Menschenalter? Anmerkungen zur Unterscheidung zwischen Unrecht und Schuld im Strafrecht”, en: DANNECKER ET AL (Eds.), Festschrift für Harro Otto zum 70. Geburtstag, Colonia-Berlin-Múnich, 2007, pp. 137 y s. y 144 y ss.; MOLINA FERNÁNDEZ, Antijuridicidad, cit. nota n 7, pp. 185 y ss.
} 
WILENMANN, Javier. "Injusto y agresión en la legítima defensa. Una teoría jurídica de la legítima defensa".

El punto de partida lo constituye la asunción, vinculada en su forma más conocida a Adolf Merkel $^{95}$ a causa de su participación inicial en la discusión sobre la existencia de injustos no culpables, de que sólo después de imputar un comportamiento -lo que en ese contexto quería decir: sólo después de demostrar la plena responsabilidad del sujeto- puede atribuirse sentido jurídico del todo a éste. La imputación sería la operación espiritual de atribución de sentido que permitiría asignar consecuencias jurídicas a ciertos hechos. Sólo aquellos comportamientos que resultaran "imputables" serían constitutivos de hechos jurídicos relevantes; todo comportamiento no imputable no portaría sentido jurídico alguno. De esta forma, por ejemplo, las categorías jurídicas atribuirían el mismo sentido al comportamiento de un demente que a una tormenta destructiva, esto es, se trataría en ambos casos de casualidad jurídica que afecta intereses jurídicamente resguardados: ciertamente puede apreciarse una afectación del sustrato material de derechos subjetivos al ser destruida una cosa por un demente o por una tormenta, pero al no cumplirse los presupuestos de la imputación en ninguno de los dos casos, no podría apreciarse una vulneración de los derechos subjetivos mismos ${ }^{96}$. En la teoría de las normas imperativista de fines del siglo XIX, la misma premisa tendía a ser expresada dando cuenta que un legislador que quisiera que sus órdenes fueran obedecidas se desautorizaría a sí mismo de dirigirse a sujetos que no pueden ser influenciados normativamente ${ }^{97}$. Por ello, bajo asunción de racionalidad del legislador, sólo podrían ser destinatarios de las normas los capaces de culpabilidad. ${ }^{98}$ Como, sin embargo, el concepto de agresión antijurídica requeriría precisamente la calificación de un comportamiento como contrario a las normas -en ese sentido, de un injusto-, la interpretación del concepto en cuestión seguiría estructuras generales de la teoría del derecho y de la teoría del injusto penal que llevarían a imponer requisitos sumamente exigentes al reconocimiento de la situación de legítima defensa.

La tesis de la inserción sistemática de la agresión antijurídica en la teoría general del hecho punible (en ese entonces, mejor: del injusto criminal) parece ser consistente si uno asume,

\footnotetext{
${ }^{95}$ Ello ciertamente no quiere decir que se trate de una representación original de Merkel. La teoría clásica de la imputación, al constituir la imputatio facti en condición previa de la imputatio iuris, manifiesta exactamente la misma asunción conceptual, de la misma forma que lo hace el concepto hegeliano de acción.

${ }^{96}$ MERKEL, Adolf, Kriminalistische Abhandlungen, Leipzig, 1867, pp. 44 y ss. Directamente vinculado al problema de la concesión de legítima defensa frente a agresiones provenientes de incapaces de culpabilidad, HÄLSCHNER, Strafrecht 2, cit. nota $n^{\circ}$ 59, p. 263: "El peligro que me amenaza y proviene de un demente, de un perro o del fuego, tiene exactamente el mismo significado, y de la misma forma debe ser calificado jurídicamente del mismo modo, con independencia de que, para salvar mi vida o mi salud, demuela parcialmente la casa del vecino para evitar el fuego, o mate un perro ajeno, o hiera al demente." En todos esos casos se trataría de acciones en estado de necesidad y no de legítima defensa, ya que la agresión antijurídica y no, en cambio, la afectación material amenazante sería aquello que justifica el desarrollo de la acción defensiva.

${ }^{97}$ Véase con mayor detalle NAGLER, "Der heutige Stand der Lehre der Rechtswidrigkeit", en: Festschrift für Karl Binding, Tomo II, Leipzig, 1911, pp. 331 y ss.; KAUFMANN, Armin, Lebendiges und Totes in Bindings Normentheorie, Gotinga: Schwartz, 1954, pp. 121 y ss.; HAAS, Kausalität, cit. nota ${ }^{\circ} 15$, pp. 84 y s.

${ }^{98}$ HOLD VON FERNECK, Alexander, Die Rechtswidrigkeit. Eine Untersuchung zu den allgemeinen Lehren des Strafrechtes. Erster Band: Der Begriff der Rechtswidrigkeit, Jena, 1903, pp. 355 y ss. También, sin asumir premisas imperativistas, BINDING, Karl, Die Normen und ihre Übertretung. Eine Untersuchung über die rechtsmässige Handlung und die Arten des Delikts, Band 1: Normen und Strafgesetze, reimpresión de la $4^{\mathrm{a}}$ edición, Aalen: Scientia, 1965, pp. 134; 243 y s. Crítico, desde la propia teoría de los imperativos, BIERLING, Ernst, Juristische Prinzipienlehre, Dritter Band, Aalen: Scientia Verlag, 1961 (reimpresión de la edición publicada en Friburgo y Leipzig, 1894), pp. 172-174.
} 
de alguna otra forma, la idea de que sólo a través de un procedimiento interpretativo auxiliar que sigue reglas de imputación puede otorgarse sentido jurídico a un comportamiento. Defendida de esta forma, ella resultaba, sin embargo, problemática en relación con las consecuencias a las que parecía llevar: la agresión antijurídica debiera cumplir las condiciones generales de imputación de un comportamiento en su reconocimiento como injusto, lo que excluiría, entre otras cosas, la defensa frente a inimputables fuera de los estrechos márgenes del estado de necesidad agresivo. Por cierto, esta consecuencia no era en general aceptada por los defensores de la idea de la inexistencia de un injusto no culpable ${ }^{99}$. Las razones que permiten justificar la evitación de esta consecuencia son, sin embargo, limitadas y, en general, poco convincentes.

Una primera forma de intentar justificar la procedencia de la legítima defensa respecto de inimputables consiste precisamente en negar la inserción sistemática del concepto de agresión antijurídica. Ello implica combinar la teoría de la inexistencia del injusto no culpable (o, alternativamente, la reducción del destinatario de las normas a los capaces de imputación) con una comprensión de la legítima defensa que precisamente niegue toda conexión entre ambas. La forma en que esto típicamente era defendido consistía en sostener que la legítima defensa sería una institución centrada en la perspectiva de la víctima y a cuyo respecto la calificación normativa expresada por el concepto de injusto penal -un concepto centrado en la perspectiva del autor- no tendría aplicación, por lo que lo relevante sería la simple determinación de si se trata de un comportamiento que el agredido debe o no soportar. Esta era, de hecho, la posición defendida por el gran paladín de la inexistencia del injusto puramente objetivo, Adolf Merkel ${ }^{100}$. La combinación de las dos tesis parece ser, sin embargo, difícilmente justificable en Merkel: un argumento de esta clase es derechamente contradictorio con su férrea defensa de la exclusión del injusto no culpable por considerar que sin un juicio de imputación mínimo el comportamiento simplemente carecería de todo sentido jurídico ${ }^{101}$. Si no es posible atribuir sentido jurídico a un comportamiento sin llevar a cabo un juicio de imputación y todo riesgo que surja de un comportamiento no culpable debe ser visto como una casualidad natural, parece ser necesario concluir que toda agresión de un inimputable constituye un caso de necesidad creada por una casualidad natural, esto es, un caso de estado de necesidad.

Algo similar puede decirse de la reconstrucción de la legítima defensa frente a inimputables como una decisión legislativa de someter el tratamiento de un caso de estado de necesidad a los estándares de acción de la legítima defensa expuesto, entre otros, por Karl Binding en una de sus múltiples tomas de posición frente a este punto ${ }^{102}$. Este argumento por así decir

\footnotetext{
${ }^{99}$ No así HÄLSCHNER, Strafrecht 2, cit. nota n ${ }^{\circ}$ 59, p. 263 y s.; y HOLD VON FERNECK, Alexander, Die Rechtswidrigkeit. Eine Untersuchung zu den allgemeinen Lehren des Strafrechtes. Zweiter Band. Erste Abteilung: Notstand und Notwehr, Jena, 1905, p. 123. Menos claro, pero en el mismo sentido, el trabajo fundamental de BERNER, Nothwehrtheorie, cit. nota ${ }^{\circ} 21$, pp. 554 y ss.

100 MERKEL, Adolf, Lehrbuch des Strafrechts, Stuttgart, 1889, p. 163. Similar también BINDING, Handbuch, cit. nota $\mathrm{n}^{\circ} 2$, p. 740.

${ }^{101}$ Correctamente LÖFFLER, Alexander, "Unrecht und Notwehr. Prolegomena zu einer Revision der Lehre der Notwehr", en: Zeitschrift für die gesamte Strafrechtswissenschaft 1901, pp. 550 y s. La misma contradicción valorativa puede reconocerse en la postura de KÖSTLIN, System, cit. nota n ${ }^{\circ} 21$, pp. 85 y ss. Al respecto véase también NK-KINDHÄUSER, § 32 Nm. 20.

102 BINDING, Normen I, cit. nota ${ }^{\circ} 98$, p. 485.
} 
WILENMANN, Javier. "Injusto y agresión en la legítima defensa. Una teoría jurídica de la legítima defensa".

"decisionista" tampoco resulta convincente. La debilidad del argumento no se encuentra en que el derecho positivo no pueda hacer algo así. Por supuesto, siempre es posible asumir que una consecuencia jurídica constituye una expresión de lo simplemente positivo y que su aparente contradicción con algún principio sistemático no influye, por ello, en la posibilidad de explicar la procedencia de la consecuencia en cuestión. Tratándose, sin embargo, de un punto que no se encuentra positivamente fijado sino que está sujeto a márgenes de indeterminación positiva -lo único que dice el derecho positivo es que la legítima defensa se encuentra sujeta a la presencia de una "agresión antijurídica" (o, entre nosotros, "ilegítima")-, el mero reenvío a una decisión es confuso. De lo que se trata aquí no es simplemente de explicar una consecuencia jurídica claramente establecida en la ley, sino de determinar la consecuencia jurídica que establece la ley en una situación de relativa indeterminación jurídica. La apelación a lo simplemente positivo no funciona en ese contexto.

Lo anterior parece sugerir incompatibilidad entre la tesis de la inexistencia del injusto no culpable (ie: sin un juicio auxiliar de imputación) y la tesis de la no inserción sistemática de la agresión antijurídica. Es decir, toda concepción que pretenda reconocer falta de seguimiento del derecho sólo cuando pueda apreciarse capacidad de seguir la norma en cuestión debiera, si pretende evitar incurrir en contradicciones sistemáticas, resignarse a la conclusión de que el concepto de agresión antijurídica o ilegítima sólo puede referirse a comportamientos dolosos y perpetrados por sujetos capaces de culpabilidad, dejando todos las demás formas de defensa entregadas a los estrictos estándares del estado de necesidad agresivo. La idea ambiciosa de que el juicio de contrariedad a derecho es una unidad de sentido no cercenable llevaría, de esta forma, necesariamente a una concepción estrecha de la agresión antijurídica. Esta era, de hecho, la posición sostenida por Hold von Ferneck, pese a asumir lo poco razonable que ella resultaba de lege ferenda.

Lo irrazonable que resulta la conclusión de que el agredido por un inimputable se encuentra en una posición normativa de estado de necesidad agresivo, puede ser elocuentemente ilustrado a partir del siguiente caso tomado de Löffler.

“(...) un demente me amenaza y sólo salvarme, en caso que logre desviar su ira hacia A o hacia B. Nadie puede pensar en este caso de que por causa de alguna disposición jurídica, de una norma de la moral social o de la razón, estoy obligado a preferir a A o a B. Asumamos, en cambio, que tengo la opción de matar al agresor demente o de desviar su ira haca A. De acuerdo a la opinión contraria [a la sostenida por Löffler, JW], me encuentro en una situación de necesidad con dos posibilidades equivalentes de salir de ella. Y, sin embargo, la razón y el derecho llevan a afirmar que debo dañar al agresor inimputable y no, en cambio, al tercero inocente."

Los problemas de esta postura van, sin embargo, más allá. Sostener un concepto tan estrecho de legítima defensa no resulta sólo poco sensato en sus consecuencias, sino que parece encerrar además una contradicción con una idea mínima de justicia como correspondencia. Aquello que explica las dificultades en el tratamiento de la defensa frente a inimputables que han tenido los partidarios de una concepción restringida del injusto es la

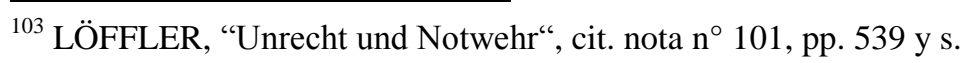


posible asimetría en el reconocimiento de posiciones jurídicas que parece darse si uno niega toda posibilidad de defensa frente a ellos. Los derechos subjetivos del agredido dejarían de tener reconocimiento real frente a inimputables, ya que en principio no sólo no habría posibilidad de defenderlos sino que tampoco serían aplicables consecuencias jurídicopenales en caso de afectación de su sustrato material por el inimputable, mientras que la afectación de los derechos subjetivos del inimputable sí harían aplicable las penas correspondientes y, en cualquier caso, el inimputable podría defenderse. ${ }^{104}$ Es precisamente el reconocimiento de derechos del inimputable frente al capaz de culpabilidad (lo que quiere decir: el hecho de que las prohibiciones jurídicas de afectación de ciertos sustratos materiales también se refieran al inimputable y que sean consideradas infringidas por un capaz de culpabilidad siempre que éste lesione los intereses en cuestión) la razón por la que la defensa parece ser calificada como prohibida por el derecho: porque afecta los derechos reconocidos a la intangibilidad corporal (o a la libertad, o a la propiedad, etc.) del inimputable. Incluso más: como los derechos subjetivos del imputado son por definición reconocidos, éste sí podría defenderse en legítima defensa en caso de ser agredido por un individuo capaz de culpabilidad, estando éste con ello obligado a soportar la lesión que se sigue de esta defensa. La asimetría de posiciones es, de esta forma, completa. Pero si esto es así, la distribución de autonomía afirmada por esta interpretación de las normas no parece ser justificable: ¿qué justifica que reconozcamos espacios tan amplios de autonomía a inimputables, de forma tal que incluso tengan un verdadero permiso de matar a cualquier tercero?

Ello parece sugerir la necesidad de buscar alguna corrección en la interpretación del concepto de agresión antijurídica, abandonando la pretensión de mantener una conexión entre calificación normativa de una situación y atribución de capacidad de evitación de esa situación, esto es, abandonar la demarcación de Abegg y Berner entre estado de necesidad y legítima defensa haciendo referencia a la calidad de verdadero injusto -de contradicción del derecho- de la agresión y con ello de asunción de la lesión que se sigue de la defensa por parte del agresor ${ }^{105}$.

Detrás de esta intuición se encuentra ciertamente una asunción dogmática justificada: las condiciones de legitimación de la imposición de la pena, respecto a las cuales se construye al menos en parte la idea de culpabilidad, no son idénticas a las condiciones de legitimación de la concesión de facultades lesivas para prevenir la afectación del sustrato material de los derechos del afectado, incluso cuando ello tiene lugar por vulneración de esos derechos subjetivos. ${ }^{106}$ Pero también es analíticamente posible, al revés, abandonar más bien la pretensión de encontrar una concepción unitaria del injusto en la teoría del hecho punible y en la dogmática de la legítima defensa, construyendo reglas de imputación diferenciadas, siendo incluso posible -ello es lo que revela el "descubrimiento" del estado de necesidad

\footnotetext{
${ }^{104}$ Cercano, aunque haciendo referencia ante todo a la expectativa cultural de no realización de lo prohibido por las normas respecto de los inimputables, BIERLING, Prinzipienlehre III, cit. nota n ${ }^{\circ}$ 98, p. 174.

${ }^{105}$ ABEGG, Untersuchungen, cit. nota ${ }^{\circ}$ 69, p. 122; BERNER, Nothwehrtheorie, cit. nota $\mathrm{n}^{\circ} 21$, pp. 554 y ss.

${ }^{106}$ Correctamente en relación con la función de la culpabilidad ya BIERLING, Prinzipienlehre III, cit. nota ${ }^{\circ}$ 98, pp. 189 y ss. Similar PAWLIK, Unrecht, cit. nota n 62, p. 268; NAGLER, "Rechtswidrigkeit", cit. nota $\mathrm{n}^{\circ}$ 97, p. 341; ENGISCH, Karl, Untersuchungen über Vorsatz und Fahrlässigkeit im Strafrecht, Aalen: Scientia, 1964 (reimpresión de la edición original publicada en Berlín en 1930), p. 61.
} 
WILENMANN, Javier. "Injusto y agresión en la legítima defensa. Una teoría jurídica de la legítima defensa".

defensivo gatillado por un comportamiento humano- diferenciar varios subsistemas de reglas de imputación de esta clase. Con ello, la solución de los problemas sistemáticos que afectan al concepto de agresión antijurídica parece poder tener lugar por uno de dos arreglos conceptuales: (i) abandonar la idea de la continuidad sistemática entre agresión e injusto del hecho punible; o (ii) mantener la idea de continuidad sistemática, pero desinflando la concepción del injusto por medio de la extracción de los presupuestos que son propiamente relativos a la legitimación de la pena.

\subsection{La tesis de la inserción sistemática y la distinción entre injusto y culpabilidad.}

La dogmática mayoritaria en Alemania ha seguido el segundo camino, el que, como veremos, no ha resultado convincente no sólo por razones sustantivas relativas a los fundamentos del concepto de agresión antijurídica defendido por ésta, sino que también encierra contradicciones sistemáticas.

El punto de partida de la concepción unitaria del injusto defendida por la doctrina mayoritaria en el contexto del concepto de agresión, es la generación de una distinción fuerte entre injusto -como juicio relativo al disvalor de un hecho en relación con los intereses protegidos por normas; la norma aparecería aquí como norma de valoración- y culpabilidad -como juicio ulterior de reprochabilidad, por incumplimiento de una obligación personal, por la realización de ese hecho; la norma aparecería como norma de determinación- legada, entre otros, por Mezger ${ }^{107}$. El injusto sería de esta forma la expresión de un juicio hecho en relación al momento de protección que caracteriza, como estándar de valoración, al derecho penal, mientras que la culpabilidad constituiría un juicio efectuado respecto del momento de obligación constituido por las normas penales ${ }^{108}$. "El punto principal que favorece la distinción entre antijuridicidad y culpabilidad es la posibilidad de distinguir en la norma jurídica dos tipos de funciones: valorativa $y$ prescriptiva. ${ }^{109 "}$ Esto es: el hecho punible es reconstruido como la conjunción de la contrariedad de un hecho a la norma como estándar de valoración en la protección de bienes jurídico sumado a una infracción de una obligación personal de no producción de ese estado: "De acuerdo a su esencia, el hecho punible es la afectación de un bien jurídico

\footnotetext{
${ }^{107}$ MEZGER, Edmund, "Die subjektiven Unrechtsmerkmalen”, en: Der Gerichtssaal 1924, pp. 240 y ss.; EL MISMO, "Die Straftat als Ganzes”, en: Zeitschrift für die gesamte Strafrechtswissenschaft 1938, pp. 693-695; EL MISMO, Deutsches Strafrecht. Ein Leitfaden, Berlín: Junker und Dünnhaupt, 1936, p. 45. Crítico PAWLIK, "Unrecht und Schuld", cit. nota ${ }^{\circ}$ 94, pp. 137 y s. En los hechos, ella ya se encontraba ampliamente defendida a la época del Schulenstreit. Véase V. HIPPEL, Robert, Deutsches Strafrecht, Band 2: Das Verbrechen, Aalen, Scientia, 1971 (reimpresión de la edición de Berlín, 1930), pp. 184 y ss.

${ }^{108}$ Al respecto AST, Stephan, Normentheorie und Strafrecht, Berlín: Duncker \& Humblot, 2010, pp. 64-70; OTTO, Harro, Pflichtenkollision und Rechtswidrigkeitsurteil, $3^{\mathrm{a}}$ Edición, Marburgo: Elwert, 1978, pp. 2 y s.; PAWLIK, "Unrecht und Schuld”, cit. nota n 94, pp. 137 y ss.; EL MISMO, Unrecht, cit. nota n 62, pp. 261 y ss.; MATT/RENZIKOWSKI, § Vor. 13 Nm. 39. La doctrina mayoritaria no necesariamente acepta, sin embargo, el arreglo normativo de Mezger, en el sentido de considerar que la norma de determinación (ie comportamiento) no se ve como tal contravenida con la afirmación del injusto. Lo crucial tiende a encontrarse en la distinción entre valoración conforme a la idea de protección de bienes jurídicos y culpabilidad como reproche. Así, por ejemplo, V. HIPPEL, Strafrecht 2, cit. nota n 107, pp. 186 y s.

${ }^{109}$ MOLINA FERNÁNDEZ, Antijuridicidad, cit. nota ${ }^{\circ} 6$, pp. 63 y s.
} 
(...) y la lesión de una obligación. ${ }^{110 ", ~ D e ~ e s t a ~ f o r m a, ~ c o m o ~ e l ~ m o m e n t o ~ d e l ~ i n j u s t o ~ n o ~}$ implica un juicio de reprochabilidad a la persona por la producción de un estado de cosas que no debe ser soportado, éste definiría exclusivamente aquello que no debe ser soportado $^{111}$. Con ello, los partidarios de este arreglo conceptual pueden sostener que la causalidad jurídica no se ve constituida por el hecho no imputable (es decir, no culpable) como asumía la dogmática tradicional, sino por el hecho no injusto ${ }^{112}$. Es esta definición del injusto como conjunto de condiciones que presentan un disvalor de acción mínimo y un disvalor de resultado completo aquello que define a una agresión ilegítima como hecho que no debe ser soportado ${ }^{113}$. La tesis de la continuidad sistemática entre injusto y agresión ilegítima puede sostenerse, por ello, con plena continuidad, evitando al menos aparentemente las consecuencias absurdas de la defensa de una continuidad completa bajo un concepto especialmente exigente de injusto.

Que una construcción de esta clase puede ser correctamente integrada en una teoría de las normas, es algo que ha sido demostrado ante todo por los trabajos de Armin Kaufmann en relación al problema del destinatario. Normativamente considerado el juicio de verificación de un injusto criminal podría ser descompuesto en dos: un juicio de valor de la producción de un estado de cosas por un sujeto (la contrariedad a la norma; Normwidrigkeit) y un juicio personal de contrariedad al deber establecido en la norma (Pflichtwidrigkeit) ${ }^{114}$. Asumiendo la posibilidad de practicar esta diferencia analítica, Merkel y Binding habrían afirmado apresuradamente que la calificación de antijuridicidad no es aplicable a inimputables y, en general, a quienes no cumplan las condiciones de actuación culpable. De la misma forma, los inimputables sí serían destinatarios de las normas, en tanto estándar de valoración del comportamiento $^{115}$. Especialmente acertada es la explicación de Kaufmann de las razones por las que, contra las intuiciones de los hegelianos, Merkel o (en parte) Binding, la interpretación de las normas penales como estándar de valoración de comportamientos de inimputables sí tiene sentido:

110 SCHÖNKE/SCHRÖDER/LENCKER/EISELE, Vorbem. § 13ff. Nm. 8. La misma idea tiende a ser expresada sosteniendo que el injusto representa un juicio al hecho, mientras que la culpabilidad constituye un juicio al hechor. Así también CONINX, Solidaritätsprinzip, cit. nota $\mathrm{n}^{\circ}$ 62, pp. 17 y s.; HOFFMANNHOLLAND, Klaus, Strafrecht Allgemeiner Teil, 2a Edición, Tubinga: Mohr-Siebeck, 2011, Nm. 39; SATZGER/SCHMITT/WIDMAIER/KUDLICH, Vor. § 13ff. Nm. 4; MAURACH/ZIPF, $A T$, cit. nota $n^{\circ} 2, \S$ 24 Nm. 14-21; JESCHECK/WEIGEND, AT, cit. nota n² 28, pp. 196 y s.

111 Véase a este respecto también MK-FREUND, Vor $\S \S 13 \mathrm{ff} . \quad$ Nm. 20; SCHÖNKE/SCHRÖDER/LENCKNER/EISELE, Vorbem. §§ 13ff. Nm. 12; ROXIN, AT, cit. nota ${ }^{\circ} 28, \S 7$ Nm. 65-66; STRATENWERTH, Günther, y KUHLEN, Lothar, Strafrecht Allgemeiner Teil, $6^{\mathrm{a}}$ Edición, Múnich: Beck, 2011 AT, §7 Nm. 20.

${ }^{112}$ CONINX, Solidaritätsprinzip, cit. nota ${ }^{\circ} 62$, p. 37.

113 Sobre la mezcla de elementos mínimos de evitación personal y de elementos objetivos relativos a la dañosidad social en el concepto de injusto, véase sólo, con ulteriores referencias, SILVA SÁNCHEZ, Jesús María, “¿Adiós a un concepto unitario de injusto en la teoría del delito?”, InDret 3 (2014), pp. 1-3.

${ }^{114}$ Similar entre nosotros LUZÓN PEÑA, Curso I, cit. nota n ${ }^{\circ} 29$, pp. 340 y s., distinguiendo entre norma objetiva de determinación en el ámbito del injusto y norma subjetiva de determinación en el ámbito de la culpabilidad.

115 KAUFMANN, Lebendiges, cit. nota $\mathrm{n}^{\circ}$ 97, pp. 124 y ss.; EL MISMO, Armin, Die Dogmatik der Unterlassungsdelikte, Gotinga: Schwartz, 1959, pp. 7 y ss. Similar ya NAGLER, "Rechtswidrigkeit", cit. nota n 97, pp. 283 y s.; y GOLDSCHMIDT, James, Der Notstand, ein Schuldproblem, Viena: Manz, 1913, pp. 284 y s. 
WILENMANN, Javier. "Injusto y agresión en la legítima defensa. Una teoría jurídica de la legítima defensa".

"Respecto de esta obligación [la aplicación puramente objetiva de la norma respecto de un hecho JW] no puede ser efectuada, en los hechos, ninguna distinción entre el lactante y el adulto, el incapaz de imputación y el capaz de realizar delitos. Lo anterior se explica porque la persona no entra aquí en consideración como sujeto, sino objeto y, en particular, como simple objeto en la distribución del patrimonio y cuestiones similares. El hombre no entra aquí en consideración como sujeto que actúa, sino como objeto de referencia en la distribución de bienes." 116

Formalmente considerado, la construcción de un juicio normativo principalmente objetivo -sin consideración de la capacidad racional de evitar la realización de lo incorrecto- se deja explicar de la siguiente forma. Las normas debieran ser consideradas expresiones de deber (Sollensätze). La comprensión correcta de aquello que constituye a una expresión de deber exigiría distinguir el deber mismo de su objeto, esto es, del estado de cosas cuya producción (prohibición) o no producción (mandato) es divalorado ${ }^{117}$. El juicio de determinación de si se produjo ese estado de cosas se dejaría así reconstruir con relativa independencia del juicio definitivo de determinación de incumplimiento de la norma en tanto fuente de obligación. Más allá de su mayor sofisticación y del esbozo de la presentación de un fundamento material a la concesión de valor al puro "injusto" para efectos de la construcción de los derechos de defensa, la construcción de Kaufmann mantiene la misma lógica que la distinción original de Mezger y, a partir de ello, que los arreglos conceptuales asumidos por la dogmática mayoritaria. Se trata, de esta forma, de la mejor presentación normológica de la tesis de la inserción sistemática del concepto de agresión en la teoría del hecho punible ${ }^{118}$.

Sin embargo, con independencia de la dudas que pueda plantear la disección del injusto criminal en un momento de protección y un momento de obligación en el contexto de la teoría del hecho punible, es ciertamente correcta la orientación expresada por este arreglo conceptual en el contexto de los derechos de defensa ${ }^{119}$. La intuición en relación a que las

\footnotetext{
${ }^{116}$ KAUFMANN, Lebendiges, cit. nota ${ }^{\circ} 97$, p. 127.

${ }^{117}$ KAUFMANN, Lebendiges, cit. nota $\mathrm{n}^{\circ}$ 97, p. 130. Similar, afirmando la obviedad de la distinción, MOLINA FERNÁNDEZ, Antijuridicidad, cit. nota n ${ }^{\circ}$ 6, pp. 63-65.

${ }^{118}$ Esta afirmación puede ser matizada si uno considera que, adicionalmente, Kaufmann se encontraba comprometido con una distinción mucho más problemática entre contrariedad a una norma y contrariedad al derecho como expresión de una distinción entre contrariedad abstracta de estándares distributivos, siempre socialmente problemática, y contrariedad además concreta. Como, sin embargo, la contrariedad a la norma ya definiría un injusto distributivo y sería ésta la dimensión que justificaría la concesión de derechos de defensa, pareciera que bastaría la tipicidad del comportamiento para que éstos procedan. Ciertamente Kaufmann no quería defender la conclusión (absurda) de que hay derechos de defensa frente a comportamientos justificados, pero sus arreglos conceptuales fundamentales llevan a considerar esto. Sobre la inserción de la polémica respecto a la distinción entre atipicidad y justificación en la teoría de las normas de Kaufmann, véase con más detalle WILENMANN, "Injusto", cit. nota n 79, pp. 144-151.

${ }^{119}$ Esto es identificado por MOLINA FERNÁNDEZ, Antijuridicidad, cit. nota n ${ }^{\circ} 6$, pp. 81 y ss., al dar cuenta de las necesidades prácticas vinculadas a la distinción de juicios de injusto en el contexto de la legítima defensa. Incluso los partidarios de un concepto estricto de injusto reconocen esto. Como correctamente ha señalado recientemente SILVA SÁNCHEZ, “iAdiós a un concepto?”, cit. nota $\mathrm{n}^{\circ} 113$, pp. 9 y s., la propia distinción ensayada por Pawlik - uno de los más elocuentes críticos de la posibilidad de efectuar del todo una distinción entre injusto y culpabilidad - entre fundamentación de competencia y teoría de la imputación pone de relieve exactamente la misma necesidad de admitir orientaciones que trasciendan la pura identificación de una actuar reprochable en contra de las normas. La pregunta, sin embargo, es si el arreglo sistemático
} 
necesidades de protección, derivadas de una distribución justa de autonomía no pueden ser satisfechas asumiendo una teoría de las normas o del injusto estrictamente orientada a identificar infracciones plenamente responsables de normas, se ve demostrado no sólo por la necesidad constante que ha manifestado la dogmática de extender la comprensión de la legítima defensa, sino ante todo por el hecho de que pese a esa extensión, ésta ha visto necesario extenderlos todavía más a través del reconocimiento del estado de necesidad defensivo. Esto es: parece intuitivamente absurdo sostener que la defensa frente a inimputables (o frente a cosas, en el caso original del estado de necesidad defensivo) no puede tener lugar, incluso si su omisión acarrea la muerte del agredido, porque el derecho no los reconoce como agentes racionales capaces de orientarse al seguimiento de las normas.

Pese a ello, el arreglo conceptual sostenido por la dogmática mayoritaria, aplicado en este contexto exclusivamente a la definición de los derechos de defensa, se revela como sistemáticamente insuficiente y contradictorio por dos clases de razones inversas entre sí: se trata, a la vez, de una construcción demasiado estrecha y demasiado amplia ${ }^{120}$. Así, por una parte, el concepto de agresión construido de esta forma es incapaz de cubrir todos los casos en que se justifica la concesión de derechos de defensa. Pese a ello, esta concepción no permite desarrollar, por la otra, un concepto de agresión ilegítima que permita justificar en todos los casos la enorme extensión de la acción de defensa de la legítima defensa y por ello ha debido recurrir a la construcción de limitaciones ad-hoc (muy cándidamente denominadas, precisamente por su carácter ad-hoc, limitaciones "ético-sociales") ${ }^{121}$.

El primer problema se origina en la forma que tiene el arreglo conceptual aplicado por la dogmática mayoritaria al construir el concepto de agresión. El concepto de injusto que es aplicado para definirlo opera exclusivamente sobre la separación de dos momentos que caracterizan al hecho punible como todo. La aplicación de este concepto desinflado de injusto no constituye, de esta forma, un cambio de modelo teórico en el análisis de la legítima defensa y, ante todo, del estado de necesidad defensivo como pretende serlo - esto es, como modelo de determinación consistente de aquello que no debe ser soportado -, sino simplemente la aplicación de parte de un modelo orientado a identificar las condiciones en que la aplicación de un castigo es legítimo ${ }^{122}$. El modelo de la teoría del hecho punible se encuentra construido desde su inicio, sin embargo, precisamente para identificar vulneraciones plenamente responsables de normas, al menos en la forma en que es generalmente defendido. La extracción de parte de los requisitos no implica que el modelo

efectuado al aplicar la distinción entre injusto y culpabilidad para satisfacer la necesidad reconocida por todos se deja justificar sin incurrir en contradicciones. Como veremos, este no es el caso.

${ }^{120}$ En el mismo sentido, pero respecto a la unidad del concepto de injusto en su aplicación a las medidas de seguridad, SILVA SÁNCHEZ, “¿Adiós a un concepto?”, cit. nota n 113, pp. 4-5.

${ }^{121}$ Así también KINDHÄUSER, "Unrecht", cit. nota n 2, p. 495: "Las limitaciones ético-sociales pueden ciertamente servir como un vehículo útil para no permitir casos de eclatante inadecuación de la legítima defensa, pero simplemente dejan en claro que la fundamentación de la legítima defensa se encuentra posada, en algunos puntos, sobre bases débiles." Similar, aunque criticando antes las inconsistencias con los fundamentos de una teoría individualista o dualista de la legítima defensa, SCHMIDHÄUSER, "Wertstruktur", cit. nota n' 12, p. 187.

${ }^{122}$ En el fondo similar RENZIKOWSKI, Joachim, "Intra- und extrasystematische Rechtfertigungsgründe", en: BYRD y JOERDEN (Eds.), Philosophia Practica Universalis; Festschrift für Joachim Hruschka zum 70. Geburtstag, Berlín: Duncker \& Humblot, 2005, p. 655. 
WILENMANN, Javier. "Injusto y agresión en la legítima defensa. Una teoría jurídica de la legítima defensa".

abandone esa orientación normativa ${ }^{123}$. Esto es evidente al exigir el cumplimiento de las condiciones que en la secuencia de la teoría del delito caracterizan al injusto: acción, típica y antijurídica. La dogmática ciertamente admite que no es necesario que la acción sea penalmente típica en este caso, sino que se bastaría que se trate de una conducta considerada antijurídica en relación con cualquier clase de regla del derecho. Pero el requisito de acción es, en cambio, prácticamente unánimemente exigido. ¿Por qué, sin embargo, es necesario que en caso de puesta en peligro mediante cosas ajenas, el dueño haya realizado alguna acción que explique la puesta en peligro como condición para que yo pueda defenderme frente a ellas? Este es el viejo problema de la defensa frente a animales, solucionado en Alemania ciertamente por la cláusula positiva del $\S 228$ BGB, pero sin que pueda encontrar una explicación realmente satisfactoria en la teoría de las causas de justificación. Esta incapacidad de explicación teórica se debe a la permanencia del modelo de la acción, el que se encuentra pragmáticamente orientado a la identificación de incumplimiento de normas como reglas de conducta, al hacer depender la extensión de los derechos de defensa del injusto en la comprensión dominante. La acción es la unidad definida como esencial para que pueda hablarse de posibilidad de evitar la realización del hecho antijurídico, esto es, se encuentra construida sobre un modelo orientado no a la verificación de aquello que no debe ser soportado, sino a verdaderas infracciones normativas. En el caso de la defensa frente a cosas, el modelo parece simplemente no funcionar.

La dogmática mayoritaria ha ido, sin embargo, todavía más lejos. La dependencia del concepto que define lo que debe ser soportado (el injusto) del modelo de la acción, ha hecho que legítima defensa haya debido ser complementada por el estado de necesidad defensivo más allá de la cláusula del $§ 228$ BGB en todos los casos en que ella literalmente no da el ancho, esto es frente a "no acciones", "acciones conforme a derecho"; "agresiones no actuales" -ya que infringirían el principio de simultaneidad bajo una óptica centrada en la acción ya en el momento del injusto-, etc. Esto es, sin embargo, directamente contradictorio con la asunción sistemática que anima a la construcción del concepto de injusto en la dogmática mayoritaria: éste debiera por definición determinar directamente "lo que en principio no debe ser soportado", por lo que por definición todos los casos de defensa debieran estar incluidos en un concepto de legítima defensa construido de esta forma. El que precisamente algunos de los grandes exponentes del arreglo dogmático mayoritariamente aceptado en la definición de la agresión, como ante todo Roxin, hayan llevado a cabo aportes fundamentales en el reconocimiento del estado de necesidad defensivo, muestra la completa falta de sistema que hay a este respecto: su sistema conceptual debiera, por definición, incorporar todas las situaciones de defensa en el concepto de injusto, y sin embargo no puede hacerlo a propósito de los derechos de defensa. ${ }^{124}$ Esto no es casual: ello se debe a que la dogmática mayoritaria ha seguido aplicando, como veremos con más detalle a propósito del estado de necesidad defensivo, el modelo de la acción para definir algo que no se deja definir conforme a este sistema. Esta

\footnotetext{
${ }^{123}$ Con más detalle WILENMANN, Freiheitsdistribution, cit. nota n ${ }^{\circ}$ 50, pp. 239-253.

${ }^{124}$ También crítico en el mismo sentido HAAS, Volker, "Die strafrechtliche Lehre von der objektiven Zurechnung - eine Grundsatzkritik", en: KAUFMANN y RENZIKOWSKI (Eds.), Zurechnung als Operationalisierung von Verantwortung, Fráncfort del Meno, 2004, pp. 206 y ss.; EL MISMO, Kausalität, cit. nota $\mathrm{n}^{\circ} 15, \mathrm{pp} .85-87$.
} 
falta de sistema es de hecho compensada con una institución todavía más indeterminada que el estado de necesidad defensivo comprendido bajo la forma que ha tomado en estos trabajos, a saber, el principio del interés preponderante, el que no es más que expresión de jurisprudencia intuitiva de ponderación antes que de verdadera orientación sistemática.

La construcción de un concepto de agresión constituido a partir de este concepto limitado de injusto tomado de la teoría del hecho punible no resulta convincente a su vez por la razón exactamente inversa a la anterior: es demasiado amplio para justificar la aplicación de la institución, con la enorme extensión en la fijación de la acción permitida, a todos los casos que caben dentro de su ámbito de aplicación. Como hemos visto, esta extensión sólo puede justificarse precisamente en base al modelo de la acción; los fundamentos de la legítima defensa se encuentran en la responsabilidad que carga el destinatario de la defensa por la necesidad de defenderse en la medida en que el agente debe hacerlo e. Este es, sin embargo, precisamente un fundamento que necesita ser materializado en un modelo teórico orientado a la identificación de condiciones bajo las cuales es posible y legítimo atribuir al agente capacidad concreta de evitar la producción del estado en cuestión por tratarse de un estado de cosas que infringe derechos del agente o, mejor, porque incumple obligaciones establecidas a favor del agente.

El arreglo conceptual utilizado por la dogmática mayoritaria se encuentra, de esta forma, en un dilema insoluble correctamente identificado ya por Renzikowski:

\begin{abstract}
"De acuerdo a la función de las normas como normas de comportamiento de conducir las actuaciones de los destinatarios de las normas, la lesión de las normas debe depender de la capacidad del agente de cumplir con la obligación (...). Interpretado así, sin embargo, las facultades de defensa del afectado y de esta forma su derecho subjetivo se ve reducido. Si uno orienta, en cambio, en el marco de la función de distribución de las normas de comportamiento a garantizar ampliamente intereses de integridad, entonces la regla fundamental 'impossibilium est nulla obligatio' es desconocida. Esta fricción sólo puede ser superada si uno distingue claramente la función de protección y la función de garantía del derecho."125
\end{abstract}

En el contexto de la determinación de la extensión de las causas de justificación defensivas, ello quiere decir: si uno abandona la tesis de que la dimensión reactiva de las normas es pura suma de su dimensión evaluativa o distributiva (el "injusto" de la doctrina mayoritaria) y de su dimensión de obligación y reconoce que se trata de la construcción de modelos teóricos distintos.

\title{
2.4. La agresión ilegítima como contravención normativa reconocida a través de un subsistema de reglas de imputación propias.
}

Los problemas que revela la pretensión de encontrar continuidad entre el concepto de injusto de la teoría del hecho punible ("el injusto del delito"), expresados tanto en una concepción estricta de la legítima defensa como aquella defendida por Hälschner o por

\footnotetext{
${ }^{125}$ RENZIKOWSKI, Joachim, "Normentheorie und Strafrechtsdogmatik", en: ALEXY (Ed.), Juristische Grundlagenforschung, ARSP Beiheft 104, Stuttgart, 2005, pp. 115-137, pp. 125 y s. Similar MATT/RENZIKOWSKI, Vor $§ 13$ Nm. 40.
} 
WILENMANN, Javier. "Injusto y agresión en la legítima defensa. Una teoría jurídica de la legítima defensa".

Hold von Ferneck como en una concepción que siga la distinción entre injusto y culpabilidad actualmente dominante, muestran que es necesario seguir el segundo camino descrito para encontrar una concepción sistemáticamente defendible de la agresión ilegítima. Esto es, la primera exigencia sistemática en la construcción de una teoría consistente de los derechos de defensa consiste en romper con la pretensión de inserción sistemática del concepto de agresión (o, alternativamente, del concepto de puesta en peligro responsable en el estado de necesidad defensivo) en la teoría del hecho punible.

La ruptura de esta continuidad sistemática es analítica y sustantivamente convincente incluso si uno, por razones de legitimación sustantiva, se mantiene fiel a la premisa de los hegelianos en relación a que la extensión de la acción en legítima defensa sólo puede resultar fundamentada si uno se aferra a una estructura de argumentación que permita justificar la atribución de asunción de la lesión por parte del agresor. Ciertamente esto implica reconocer una relativa continuidad de sentido entre las reglas de imputación en la teoría del hecho punible y las reglas de imputación de la legítima defensa. Pero esa continuidad es limitada. Que tanto la pena como la concesión de facultades de defensa encuentren su fundamento en la vulneración responsable de las normas que constituyen aquello que es denominado "derechos subjetivos" del afectado no implica en caso alguno que la determinación del sentido de vulnerar esas normas deba hacerse de la misma forma. Es analíticamente posible identificar un esquema de reglas de imputación con un contenido distinto tratándose del reconocimiento de un injusto que legitime la acción defensiva. Ello exige, sin embargo, romper con la pretensión de encontrar continuidad sistemática entre ese concepto de injusto y el concepto de injusto como condición (aunque sea parcial) de aplicación de la pena.

En algo que parece ser sorprendente, la idea se encuentra de hecho presente no sólo en algunos críticos de la tradición de negación de la existencia de injustos objetivos con relevancia penal, como Bierling ${ }^{126}$, sino incluso en un artículo del propio Binding publicado en el año 1910 sobre "el supuesto de hecho objetivo del injusto"12†, el que tiene además alguna continuidad con su obra posterior ${ }^{128}$. En este artículo Binding defendió la idea de que la determinación de la presencia de una agresión antijurídica ciertamente se encuentra sujeta a reglas de atribución de sentido que permiten reconocer que un comportamiento es objetivamente contrario a una norma penal en el sentido de Binding (esto es, normas de comportamiento, por oposición a la ley penal como norma de sanción) ${ }^{129}$, pero que esas

\footnotetext{
${ }^{126}$ Véase BIERLING, Prinzipienlehre III, cit. nota $\mathrm{n}^{\circ}$ 98, pp. 170 y ss., en una defensa del sentido de considerar a los inimputables destinatarios de los imperativos, al reconocerse un mínimo de voluntad.

${ }^{127}$ BINDING, Karl, "Der objektive Verbrechenstatbestand in seiner rechtlichen Bedeutung. Studien für das künftige Strafgesetzbuch", Der Gerichtssaal 76 (1910), pp. 1 y ss. Es importante tener en cuenta que el concepto utilizado por Binding en este trabajo es objektiver Tatbestand, el que hoy en día tendería a ser traducido como tipo objetivo. Sin embargo, el concepto de Tatbestand no se relaciona, en este contexto, con la idea de tipo como "descripción de una clase de conducta punible" que la dogmática maneja, con mayor o menor precisión, desde Beling. Tipo es una traducción de "Tatbestand", que en el contexto de la teoría de las normas - y en su sentido original en Alemán - significa "supuesto de hecho", esto es, el conjunto de condiciones fácticas que deben cumplirse para que una consecuencia o calificación normativa determinada sea procedente.

${ }^{128}$ Sobre el giro de Binding en relación con la construcción del concepto de injusto, MOLINA FERNÁNDEZ, Antijuridicidad, cit. nota $\mathrm{n}^{\circ} 6$, pp. 247 y ss.

${ }^{129}$ BINDING, "Verbrechenstatbestand", cit. nota n ${ }^{\circ} 127$, pp. 8 y ss.
} 


\section{Polít. crim. Vol. 10, No 20 (Diciembre 2015), Art. 7, pp. 622-677. \\ [http://www.politicacriminal.cl/Vol_10/n_20/Vol10N20A7.pdf]}

reglas de auxiliares tienen requisitos menos estrictos que las reglas de imputación en el reconocimiento de un hecho punible ${ }^{130}$. La pregunta central que determinaría la construcción de las reglas que fijan el tipo supuesto de hecho objetivo sería la "insoportabilidad (Unerträglichkeit)" del desarrollo del comportamiento objeto de la norma, en el caso de prohibiciones, o la insoportabilidad de su omisión, en el caso de mandatos. Esa atribución de sentido no se dejaría realizar, sin embargo, como se deducía del denominado esquema causalista de la teoría del delito, a través de una distinción entre el hecho en su faz externa -que constituiría el supuesto de hecho objetivo- y el hecho en su faz interna. Lo insoportable para el derecho requeriría siempre de la atribución al hecho del sentido de ser realización de la voluntad, aunque sea deficiente desde un punto de vista reactivo, de alguien ${ }^{131}$. La atribución a un comportamiento del sentido de realizar el supuesto de hecho objetivo permitiría detectar, de esta forma, aquello que es insoportable sin más para el ordenamiento jurídico a causa del daño que ocasiona. En cambio, la imputación en los términos del reconocimiento de un injusto penal permitiría reconocer el surgimiento de un enemigo del derecho ${ }^{132}$.

Correcto en la reconstrucción de Binding es la identificación de la posibilidad de construir reglas interpretativas del comportamiento dependiendo de la pretensión normativa que pretenda expresarse mediante la interpretación del comportamiento ajeno. Ello se corresponde con la ruptura, expresada ya antes del cambio de siglo por la aceptación de la independencia del injusto civil, de la pretensión de reconocer un concepto unitario de injusto $^{133}$. En el contex to de Binding, en el que todavía no era postulada una diferenciación general entre estado de necesidad defensivo y legítima defensa, esto implicaba el reconocimiento exclusivo de un modelo de reglas de imputación de responsabilidad (distributiva) por la puesta en peligro ${ }^{134}$. Esto ciertamente dejaba sin respuesta la pregunta por las razones por las que la acción defensiva no requeriría nunca considerar la posibilidad de "ceder" (huir) ante la agresión, ni la introducción de criterios de control de proporcionalidad en ciertos casos.

\footnotetext{
${ }^{130}$ BINDING, "Verbrechenstatbestand", cit. nota $\mathrm{n}^{\circ} 127$, pp. 25 y ss.

${ }^{131}$ BINDING, "Verbrechenstatbestand", cit. nota n ${ }^{\circ} 127$, pp. 10 y s. Similar EL MISMO, Die Normen und ihre Übertretung. Eine Untersuchung über die rechtsmässige Handlung und die Arten des Delikts, Band II Schuld und Vorsatz, Hälfte 1: Zurechnungsfähigkeit, Schuld, Reimpresión de la segunda edición, Aalen: Scientia Verlag, 1965, pp. 229 y ss. Como acertadamente destaca MOLINA FERNÁNDEZ, Antijuridicidad, cit. nota $n^{\circ}$ 6, p. 255, esta referencia es ambigua. Ello puede ser interpretado, sin embargo, correctamente como apertura en la determinación del contenido de las reglas auxiliares de determinación de la realización del "supuesto de hecho objetivo" de Binding.

132 BINDING, "Verbrechenstatbestand", cit. nota n 127, p. 9.

${ }^{133}$ Véase sólo MOLINA FERNÁNDEZ, Antijuridicidad, cit. nota $\mathrm{n}^{\circ}$ 6, pp. 248 y ss. Incorrecta es, sin embargo, la asunción de que ello implicó un giro "materialista" de Binding, en el sentido de eliminar el vínculo entre norma de comportamiento y calificación de antinormatividad.

${ }^{134}$ En este sentido es incorrecta la asunción de MOLINA FERNÁNDEZ, Antijuridicidad, cit. nota n 6 , pp. 261 y ss., en relación a Löffler, de que el reconocimiento de un "injusto objetivo" implique asumir como determinante la puesta en peligro de bienes jurídicos. Esta asunción es precisamente el error central de la dogmática dominante posterior a Binding, en el sentido de pasar de la correcta representación de que las instituciones penales exigen, en algunos casos, juicios normativos desligados de la perspectiva "personalísima" del autor, a la representación incorrecta de que ello exige centrarse unilateralmente en la perspectiva de la víctima y en la protección de bienes jurídicos. Esto es crucial en la dogmática del estado de necesidad defensivo.
} 
WILENMANN, Javier. "Injusto y agresión en la legítima defensa. Una teoría jurídica de la legítima defensa".

Con el reconocimiento generalizado del estado de necesidad defensivo, en cambio, es posible proceder construyendo dos subsistemas de reglas de imputación con pretensiones distintas y que sigan modelos distintos. Esto es precisamente lo que permite solucionar el dilema que ha aquejado históricamente a la legítima defensa: si se extiende demasiado, varios de los casos cubiertos por ella no dejan justificar la ausencia de consideración por el agresor, lo que exige recurrir a criterios de limitación ad hoc; si es demasiado estrecha, siguiendo de cerca el modelo de la acción, entonces la cuestión no se deja justificar desde el punto de vista del agredido. En términos sencillos, pero imprecisos: la legítima defensa debe ser una institución que mantenga una conexión con la estructura de la asunción por vulneración completa de una norma bajo el modelo de la acción, y con ello debe centrarse en el agresor, mientras que el estado de necesidad defensivo debe ser una institución distributiva centrada en la determinación de puestas en peligro que no deben ser soportadas primariamente por el agente en necesidad ${ }^{135}$. Esto no es más que traspasar los resultados de la reconstrucción sistemática de las causas de justificación derivadas de necesidad a la dogmática centrada en la reconstrucción precisa de sus requisitos. Uno puede reconocer, de esta forma, dos injustos cuya realización autoriza a la defensa frente a ellos: el injusto de la agresión, como descripción de una acción que desconoce normas constitutivas de un ámbito de autonomía ajeno; y el injusto del estado de necesidad defensivo o injusto puramente distributivo, una descripción de un estado de cosas en que el derecho impone el costo de soportar primariamente la carga ligada a una situación peligrosa.

Lo que interesa, por lo tanto, en la interpretación del concepto de agresión ilegítima, no es construir una estructura general de reglas de atribución de sentido a una puesta en peligro para identificar lo que, en términos de Binding, resulta en principio "insoportable" -la pretensión que debía haber cumplido el concepto de injusto en la comprensión mayoritaria del hecho punible-, ya que ello es una tarea de la dogmática del estado de necesidad defensivo en sentido amplio. En el contexto de la rigurosa legítima defensa en sentido estricto, se trata de construir reglas que permitan identificar verdaderas agresiones por desconocimiento de las derechos del agredido y respecto a las cuales se justifique la concesión de un derecho defenderse de la forma que sea necesaria, es decir, un verdadero caso en que el derecho no deba ceder frente al injusto ${ }^{136}$. Löffler denominaba a esta clase de agresiones, siguiendo las categorías del antiguo derecho germánico, una "agresión que rompe la paz", un ataque "también a la personalidad del portador del derecho que tiene una dimensión prácticamente injuriosa", o "una pretensión de sumisión a su señorío"137. Se trata, con ello, de construir un esquema de interpretación que permita incluir a todos los

\footnotetext{
${ }^{135}$ Una construcción notablemente similar y llevada a cabo antes del reconocimiento general del estado de necesidad defensivo fue propuesta, como MAÑALICH, "Normas permisivas", cit. nota $n^{\circ} 62$, p. 513 con nota 181, acertadamente reconoce, por LÖFFLER, "Unrecht und Notwehr", cit. nota n ${ }^{\circ} 101$, pp. 542 y s. y 574 y ss., distinguiendo dos clases de legítima defensa (mejor caracterizado por el concepto más neutral en Alemán de defensa necesaria) con estándares distintos. Una reconstrucción en el mismo sentido del sistema de derechos de defensa puede ser encontrada en BÖRGERS, Niclas, Studien zum Gefahrurteil im Strafrecht. Ein Abschied vom objektiven Dritten, Berlín: Duncker \& Humblot, 2008, pp. 107-109; MAÑALICH, "Normas permisivas", cit. nota ${ }^{\circ} 62$, pp. 513 y s. con nota 186 ;

${ }^{136}$ Similar en relación al fundamento de la legítima defensa, pese a demostrar en buena parte de su artículo la posibilidad de reconocer injustos puramente objetivos, LÖFFLER, "Unrecht und Notwehr", cit. nota $n^{\circ} 101$, pp. 567 y ss.

${ }^{137}$ LÖFFLER, “Unrecht und Notwehr”, cit. nota n 101, p. 544.
} 
Polít. crim. Vol. 10, No 20 (Diciembre 2015), Art. 7, pp. 622-677.

[http://www.politicacriminal.cl/Vol_10/n_20/Vol10N20A7.pdf]

casos y sólo a los casos en los que, en el lenguaje elocuente de Löffler, se justifica que, con excepción de la extrema desproporción, "el agredido no deba retroceder ni una pulgada ante

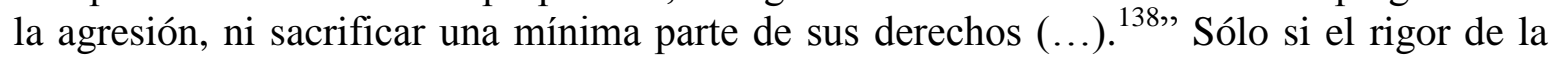
legítima defensa se limita a casos de esta clase no es posible imputarle al sistema jurídico defender la moral del homicida.

\section{Conclusiones.}

A partir de lo expuesto, pueden extraerse rápidamente algunas conclusiones determinantes en la construcción de una dogmática de la legítima defensa que no sólo resulta sustantiva y sistemáticamente convincente, sino que sea propiamente jurídica:

1) La orientación utilitarista subyacente a la dogmática de la legítima defensa manifestada en particular en la discusión entre teorías individualistas, supra-individualistas y dualistas de ésta, debe ser abandonada. Ella se encuentra en ruptura con una institución fuertemente determinada por las reglas formales del sistema como es la legítima defensa.

2) El fundamento de la legítima defensa tiene un contenido propiamente jurídico. La legítima defensa no es más que la facultad de imposición coactiva del respeto de prohibiciones (y excepcionalmente mandatos) constitutivos del núcleo de autonomía formal garantizado por el ordenamiento jurídico. La idea de responsabilidad, como fundamento de la legítima defensa, no es más que una expresión de que el injusto de la legítima defensa es constitutivo de una contravención formal del derecho identificada por medio de reglas de imputación.

3) El injusto de la legítima defensa no tiene relaciones sistemáticas directas, sin embargo, con el injusto del hecho punible. Pese a que en ambos casos se trata de conceptos al menos parcialmente determinados por reglas de imputación, la idea de que hay continuidad sistemática entre ambos conceptos de injusto $\mathrm{y}$, con ello, entre ambos sistemas de reglas de imputación lleva a resultados sistemáticamente insostenibles.

4) La agresión en la legítima defensa no constituye un arreglo conceptual cuyo objeto sea determinar lo "insoportable" desde la perspectiva del agredido, sino una acción contraria a derecho a la que todavía puede responderse preventivamente para evitar una lesión del sustrato material que subyace a las prohibiciones (o excepcionalmente mandatos) contravenidos. Ello implica el desarrollo de reglas de imputación que se mantengan en el nivel de la acción, lo que puede ser distinguido de una categoría puramente distributiva, relativa a la evaluación de la antijuridicidad de estados, como sucede en el estado de necesidad defensivo.

\footnotetext{
${ }^{138}$ LÖFFLER, “Unrecht und Notwehr”, cit. nota $n^{\circ} 101$, p. 544. Una semántica similar (tal vez uno podría decir: algo anacrónica) expresando aquello que debe ser identificado mediante el concepto de agresión puede ser encontrada en PALERMO, Legítima defensa, cit. nota $\mathrm{n}^{\circ} 1$, pp. 255 y ss.
} 
WILENMANN, Javier. "Injusto y agresión en la legítima defensa. Una teoría jurídica de la legítima defensa".

\section{BIBLIOGRAFÍA}

ABEGG, Julius, Untersuchungen zum Strafrecht, Keip: Goldbach, 1997, reimpresión de la edición publicada en Breslau, 1830.

AST, Stephan, Normentheorie und Strafrecht, Berlín: Duncker \& Humblot, 2010.

BACIGALUPO, Enrique, Derecho Penal Parte General, $2^{\text {a }}$ Edición, Buenos Aires: Hammurabi, 1999.

BALDÓ LAVILLA, Francisco, Estado de necesidad y legítima defensa, Barcelona: Bosch, 1994.

BAUMANN, Jürgen; WEBER, Ulrich; y MITSCH, Wolfgang, Strafrecht Allgemeiner Teil, $11^{\text {a }}$ Edición, Bielefeld: Gieseking, 2003.

BELING, Ernst, Grundzüge des Strafrechts, 11ª Edición, Tubinga: Mohr, 1930.

BERNER, Albert Friedrich, "Die Notwehrtheorie", en: Archiv des Criminalrechts 1848, Halle, 547-598.

BERNER, Albert Friedrich, Lehrbuch des deutschen Strafrechts, $6^{\text {a }}$ Edición, Leizpig: Tauchnitz, 1872.

BIERLING, Ernst, Juristische Prinzipienlehre, Dritter Band, Aalen: Scientia Verlag, 1961 (reimpresión de la edición publicada en Friburgo y Leipzig, 1894).

BINDING, Karl, Die Normen und ihre Übertretung. Eine Untersuchung über die rechtsmässige Handlung und die Arten des Delikts, Band 1: Normen und Strafgesetze, reimpresión de la 4a edición, Aalen: Scientia, 1965.

, Die Normen und ihre Übertretung. Eine Untersuchung über die rechtsmässige Handlung und die Arten des Delikts, Band II Schuld und Vorsatz, Hälfte 1: Zurechnungsfähigkeit, Schuld, Reimpresión de la segunda edición, Aalen, Scientia Verlag, 1965. , Handbuch des Strafrechts, Band I, Leipzig, 1885.

,"Der objektive Verbrechenstatbestand in seiner rechtlichen Bedeutung. Studien für das künftige Strafgesetzbuch”, Der Gerichtssaal 76 (1910), pp. 1-86.

BITZILEKIS, Nikolaos, Die neue Tendenz zur Einschränkung des Notwehrrechts unter besonderer Berücksichtigung der Notwehrprovokation, Berlín: Duncker \& Humblot, 1984.

BÖRGERS, Niclas, Studien zum Gefahrurteil im Strafrecht. Ein Abschied vom objektiven Dritten, Berlín: Duncker \& Humblot, 2008.

BUSTOS, Juan, Manual de Derecho Penal Español Parte General, Barcelona: Ariel, 1984.

BUSTOS, Juan y HORMAZABAL, Hernán, Lecciones de Derecho Penal, Volumen II, Madrid: Trotta, 1999.

CEREZO MIR, José, Curso de Derecho Penal Español Parte General, Tomo II, Sexta edición, Séptima reimpresión, Madrid: Tecnos, 2005.

COBO DEL ROSAL, Manuel, y VIVES ANTÓN, Tomás, Derecho Penal Parte General,

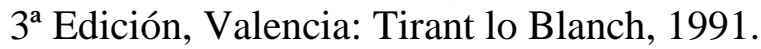

COCA VILA, Ivó, "Entre la responsabilidad y la solidaridad. El estado de necesidad defensivo", InDret 1(2011).

CONINX, Anna, Das Solidaritätsprinzip im Lebensnotstand. Zufall, rationale Entscheidung und Verteilungsgerechtigkeit, Berna, 2012. 
Polít. crim. Vol. 10, No 20 (Diciembre 2015), Art. 7, pp. 622-677.

[http://www.politicacriminal.cl/Vol_10/n_20/Vol10N20A7.pdf]

CÓRDOBA RODA, Juan, "Consideraciones sobre la legítima defensa", en: GARCÍA VALDÉS ET AL (Eds.), Libro homenaje a Enrique Gimbernat, Madrid: Edisofer, 2008, pp. 761-778.

COURAKIS, Nestor, Zur sozialethischen Begründung der Notwehr. Die sozialethischen Schranken des Notwehrrechts nach deutschem und griechischem Strafrecht, BadenBaden: Nomos, 1978.

CURY, Enrique, Derecho Penal, Parte General, Octava Edición, Santiago: Ediciones Universidad Católica, 2005.

ENGISCH, Karl, Untersuchungen über Vorsatz und Fahrlässigkeit im Strafrecht, Aalen: Scientia, 1964 (reimpresión de la edición original publicada en Berlín en 1930).

ENGLÄNDER, Armin, Grund und Grenzen der Nothilfe, Tubinga, Mohr-Siebeck, 2008.

"Die Anwendbarkeit von § 34 StGB auf intrapersonale Interessenkollisionen", en: Goltdammer's Archiv für Strafrecht 2010, pp. 15-26.

ETCHEBERRY, Alfredo, Derecho Penal, Tomo I, $3^{\text {a }}$ edición, Santiago: Editorial Jurídica, 1997.

EUE, Jens, "Anmerkung zu BGH, Urteil v. 14.3.1989 - 1 StR 25/89 (LG Tübingen)", JuristenZeitung 1990, pp. 763-768.

FEUERBACH, Paul Johan Anselm, Lehrbuch des gemeinen in Deutschland gültigen peinlichen Rechts, 13a Edición, Giessen: Geyerl, 1840.

FICHTE, Johan Gottlieb, Grundlage des Naturrechts nach Prinzipien der Wissenschaftslehre, Hamburgo, 1976 (reimpresión de la $2^{\text {a }}$ Edición de Fritz Medicus, 1922).

FISCHER, Thomas, Strafgesetzbuch Kommentar, 62ª Edición, Múnich: Beck, 2015.

FREUND, Georg, Strafrecht Allgemeiner Teil. Personale Straftatlehre, Berlín-Heidelberg: Springer, 1998.

FRISTER, Helmut, Strafrecht Allgemeiner Teil, 9a Edición, Múnich: Beck, 2013.

"Die Notwehr im System der Notrechte", en: Goltdammer's Archiv für Strafrecht 1988, pp. 291-316.

GARRIDO MONTT, Mario, Derecho Penal, Parte General, Tomo II, Tercera Edición, Santiago: Editorial Jurídica, 2003.

GEILEN, Gerd, "Notwehr und Notwehrexzeß”, Juristische Ausbildung 1981, pp. 200-210.

GOLDSCHMIDT, James, Der Notstand, ein Schuldproblem, Viena: Manz, 1913.

GRÜNEWALD, Anette, Das vorsätzliche Tötungsdelikt, Tubinga: Mohr-Siebeck, 2010.

HAAS, Robert, Notwehr und Nothilfe. Zum Prinzip der Abwehr rechtswidriger Angriffe. Geschichtliche Entwicklung und heutige Problematik, Fráncfort del Meno: Peter Lang, 1978.

Kausalität und Rechtsverletzung. Ein Beitrag zu den Grundlagen strafrechtlicher Erfolgshaftung am Beispiel des Abbruchs rettender Kausalverläufe, Berlín: Duncker \& Humblot, 2002.

"Die strafrechtliche Lehre von der objektiven Zurechnung - eine Grundsatzkritik", en: KAUFMANN y RENZIKOWSKI (Eds.), Zurechnung als Operationalisierung von Verantwortung, Fráncfort del Meno, 2004, pp. 193-224.

HÄLSCHNER, Hugo, Das preußische Strafrecht, Teil 2. Den allgemeinen Theil des Systems umfassend, Bonn, 1858.

HEGEL, Georg Willhelm Friedrich, Grundlinien der Philosophie des Rechts, en: Werke 7, Fráncfort del Meno: Suhrkamp, 1986. 
WILENMANN, Javier. "Injusto y agresión en la legítima defensa. Una teoría jurídica de la legítima defensa".

VON HIPPEL, Robert, Deutsches Strafrecht, Band 2: Das Verbrechen, Aalen: Scientia, 1971 (reimpresión de la edición de Berlín, 1930).

HOFFMANN-HOLLAND, Klaus, Strafrecht Allgemeiner Teil, $2^{\text {a }}$ Edición, Tubinga: MohrSiebeck, 2011.

HOLD VON FERNECK, Alexander, Die Rechtswidrigkeit. Eine Untersuchung zu den allgemeinen Lehren des Strafrechtes. Erster Band: Der Begriff der Rechtswidrigkeit, Jena, 1903.

, Die Rechtswidrigkeit. Eine Untersuchung zu den allgemeinen Lehren des Strafrechtes. Zweiter Band. Erste Abteilung: Notstand und Notwehr, Jena, 1905.

HOYER, Andreas, Strafrechtsdogmatik nach Armin Kaufmann. Lebendiges und Totes in Armin Kaufmanns Normentheorie, Berlín: Duncker \& Humblot, 1997.

, "Das Rechtsinstitut der Notwehr", Juristische Schulung 1988, pp. 89-96.

HRUSCHKA, Joachim, "Extrasystematische Rechtsfertigungsgründe", en: JESCHECK y LÜTTGER (Eds.), Festschrift für Eduard Dreher, Berlín-Nueva York, 1977, pp. 189210.

393.

, Strafrecht nach logisch-analytischer Methode (AT), 2ª Edición, Berlín, 1988.

"Die Notwehr im Zusammenhang von Kants Rechtslehre", Zeitschrift für die gesamte Strafrechtswissenschaft 2003, pp. 201-223.

JÄGER, Christian, Zurechnung und Rechtfertigung als Kategorialprinzipien im Strafrecht, Múnich: Müller, 2006.

JAKOBS, Günther, System der strafrechtlichen Zurechnung, Fráncfort del Meno, 2012. , Rechtszwang und Personalität, Paderborn, 2008. , Strafrecht Allgemeiner Teil, 2a Edición, Berlín-Nueva York, 1991.

, "Kommentar: Rechtfertigung und Entschuldigung aus besonderen Notlagen (Notwehr, Notstand, Pflichtenkollision)", en: ESER y NISHIHARA (Eds.), Rechtfertigung und Entschuldigung IV, Friburgo de Brisgovia: Max Planck Institut, 1995, pp. 143-177.

JESCHECK, Hans-Heinrich y WEIGEND, Thomas, Lehrbuch des Strafrechts Allgemeiner

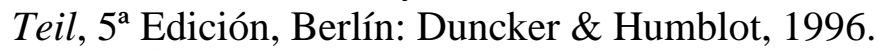

JIMÉNEZ DÍAZ, María José, El exceso intensivo en la legítima defensa, Granada: Comares, 2007.

JOERDEN, Jan, "Der Streit um die Gänsebrust. Selbsthilfe im Strafrecht", Juristische Schulung 1992, 23-28.

KANT, Immanuel, Metaphysik der Sitten, en: Werkausgabe Tomo VIII, editado por WEISCHEDEL, Fráncfort del Meno: Suhrkamp, 1977.

KARGL, Walter, "Die intersubjektive Begründung und Begrenzung der Notwehr", Zeitschrift für die gesamte Strafrechtswissenschaft 1998, pp. 38-68.

KAUFMANN, Armin, Lebendiges und Totes in Bindings Normentheorie, Gotinga: Schwartz, 1954. , Die Dogmatik der Unterlassungsdelikte, Gotinga: Schwartz, 1959.

KINDH ̈̈USER, Urs, "Zur Genese der Formel 'Das Recht braucht dem Unrecht nicht zu weichen'”, en: FREUND ET AL (Eds), Festschrift für Wolfgang Frisch, Berlín: Duncker \& Humblot, 2013, pp. 493-510. , Strafrecht Allgemeiner Teil, 5ª Edición, Baden-Baden: Nomos, 2011. 
Polít. crim. Vol. 10, No 20 (Diciembre 2015), Art. 7, pp. 622-677.

[http://www.politicacriminal.cl/Vol_10/n_20/Vol10N20A7.pdf]

Strafgesetzbuch. Lehr- und Praxiskommentar, 5 ${ }^{\text {a }}$ Edición, Baden-Baden: Nomos, 2013.

KIOUPIS, Dimitrios, Notwehr und Einwilligung. Eine individualistische Begründung, Baden-Baden: Nomos, 1992.

KLEINHERNE, Philipp Christoph, Garantenstellung und Notwehrrecht, Fráncfort del Meno: Peter Lang, 2013.

KÖHLER, Michael, Strafrecht Allgemeiner Teil, Berlin-Heidelberg: Springer, 1997.

KORIATH, Heinz, "Einige Gedanken zur Notwehr”, en: BRITZ ET AL, Festschrift für Heinz Müller-Dietz, Múnich: Beck, 2001, pp. 361-384.

"Das Brett des Karneades", Juristische Arbeitsblätter 1998, pp. 250-257.

KÖSTLIN, Christian Reinhold, Neue Revision der Grundbegriffe des Criminalrechts, Tubinga, 1845. 1855.

, System des deutschen Strafrechts. Erste Abtheilung. Allgemeiner Theil, Tubinga,

KRATZCH, Dietrich, "Der 'Angriff' - ein Schlüsselbegriff des Notwehrrechts", Strafverteidiger 1987, pp. 224-229.

KRAUß, Detler, “'Das Recht braucht dem Unrecht nicht zu weichen' ”, en: PAEFFGEN ET AL (Eds.), Festschrift für Ingeborg Puppe, Berlín: Duncker \& Humblot, 2011, 635-652.

KRAUSE, Friedrich-Wilhelm, "Notwehr bei Angriffen Schuldlosen und Bagatellenangriffen”, en: HIRSCH (Ed.), Gedächtnisschrift für Hilde Kaufmann, Nueva York/Berlín: De Gruyter, 1986, pp. 673-688.

KRETSCHMER, Joachim, "Die Rechtfertigungsgründe als Topos der objektiven Zurechnung", Neue Zeitschrift für Strafrecht 2012, pp. 177-184.

KREY, Volker y ESSER, Robert, Deutsches Strafrecht Allgemeiner Teil, 5 a edición, Stuttgart: Kohlhammer, 2012.

KROß, Antje, Notwehr gegen Schweigegelderpressung, Berlín: Duncker \& Humblot, 2004.

KUHLEN, Lothar, "La restricción de las facultades de actuación en la legítima defensa de terceros", en: GARCÍA VALDÉS ET AL (Eds.), Estudios en homenaje a Enrique Gimbernat, Madrid: Edisofer, pp. 1099-1120.

KÜHL, Kristian, "Notwehr ein Kampf ums Recht oder Streift, der misßfällt? Schlaglichter der Notwehrdiskussion der 2. Hälfte des 19. Jahrhunderts in Deutschland und Österreich”, en: SCHMOLLER (Ed.), Festschrift für Otto Triffterer, Viena-Nueva York: Springer, 1996, pp. 149-167. , Strafrecht Allgemeiner Teil, $7^{\text {a }}$ Edición, Múnich: Vahlen, 2012. ,"Notwehr und Nothilfe", Juristische Schulung 1993, 177-183.

Lackner/Kühl Strafgesetzbuch Kommentar, editado por KRISTIAN KÜHL y MARTIN HEGER, 28ª Edición, Múnich: Beck, 2014.

LADIGES, Manuel, "Erlaubte Tötungen”, Juristische Schulung 2011, pp. 879-884.

LENCKNER, Theodor, Der rechtfertigende Notstand, Tubinga: Mohr-Siebeck, 1965.

LESCH, Heiko, Notwehrrecht und Beratungsschutz. Zur Zulässigkeit der Nohilfe gegen die nach $\S 218 a$ Abs 1. StGB tatbestandslose Abtötung der Leibesfrucht, Paderborn: Ferdinand Schöningh, 2000.

, Die Notwehr, en: WIDMAIER/LESCH/MÜSSIG/WALLAU (Eds.), Festschrift für Hans Dahs, Colonia: Otto Schmidt, 2005, pp. 81-115. 
WILENMANN, Javier. "Injusto y agresión en la legítima defensa. Una teoría jurídica de la legítima defensa".

LÖFFLER, Alexander, "Unrecht und Notwehr. Prolegomena zu einer Revision der Lehre der Notwehr", Zeitschrift für die gesamte Strafrechtswissenschaft 1901, pp. 537-581.

LUDWIG, Dominik, "Gegenwärtiger Angriff", "drohende" und "gegenwärtige Gefahr" im Notwehr- und Notstandsrecht. Eine Studie zu den temporalen Erfordernissen der Notrechte unter vergleichender Einbeziehung der Gefahrerfordernisse des Polizeirechts, Fráncfort del Meno: Peter Lang, 1991.

LUZÓN PEÑA, Diego, Aspectos esenciales de la legítima defensa, Montevideo, Buenos Aires: BdeF, 2006.

, Lecciones de Derecho Penal Parte General, Segunda Edición, Valencia: Tirant lo Blanch, 2012. , Curso de Derecho Penal Parte General I, Madrid, 1996.

MAÑALICH, Juan Pablo, "Normas permisivas y deberes de tolerancia", Revista Chilena de Derecho $41 \mathrm{~N}^{\circ} 2$ (2014), pp. 473-522.

, "La estructura de la autoría mediata", Revista de Derecho de la Universidad Católica de Valparaíso 34 (2010), pp. 385-414.

MATT, Holger y RENZIKOWSKI, Joachim (Eds.), Strafgesetzbuch Kommentar, Múnich: Beck, 2013.

MAURACH, Reinhart; y ZIPF, Heinz, Strafrecht Allgemeiner Teil, Tomo 1, 8 a Edición, Heidelberg: C.F. Müller, 1992.

MERKEL, Adolf, Lehrbuch des Strafrechts, Stuttgart, 1889. , Kriminalistische Abhandlungen, Leipzig, 1867.

MERKEL, Reinhard, "Folter und Notwehr", en: PAWLIK Y ZACZYK (Eds.), Festschrift für Günther Jakobs, Colonia-Berlín-Múnich, 2007, pp. 375-403.

"§ 14 Abs. 3 Luftsicherheitsgesetz: Wann und warum darf der Staat töten?", Juristen Zeitung 2007, pp. 373-385.

MEZGER, Edmund, "Die subjektiven Unrechtsmerkmalen”, Der Gerichtssaal 1924, pp. 207-314.

, "Die Straftat als Ganzes", Zeitschrift für die gesamte Strafrechtswissenschaft 1938, pp. 675-701.

, Deutsches Strafrecht. Ein Leitfaden, Berlín: Junker und Dünnhaupt, 1936.

MICHELET, Karl Ludwig, Das System der philosophischen Moral, Berlín, 1828.

MOLINA FERNÁNDEZ, Fernando, Antijuridicidad penal y sistema del delito, Barcelona: Bosch, 2001.

MONTENBRUCK, Axel, Thesen zur Notwehr, Heidelberg: C.F. Müller, 1983.

Münchener Kommentar zum Strafgesetzbuch Tomo 1, editado por JOECKS y MIEBACH, $2^{a}$ Edición, Múnich: Beck, 2011.

MIR PUIG, Santiago, Derecho Penal Parte General, Novena Edición actualizada por Gómez Martín, Barcelona: Reppertor, 2011.

MITSCH, Wolfgang, Rechtfertigung und Opferverhalten, Hamburgo: Kovac, 2004.

MURMANN, Uwe, Grundkurs Strafrecht, Múnich: Beck, 2011.

MÜSSIG, Bernd, Mord und Totschlag, Colonia-Berlín-Múnich, 2005.

"Antizipierte Notwehr. Das Prinzip der Abwehr rechtswidriger Angriffe als Kriterium objektiver Zurechnung”, Zeitschrift für die gesamte Strafrechtswissenschaft 115 (2003), pp. 224-248. 
Polít. crim. Vol. 10, № 20 (Diciembre 2015), Art. 7, pp. 622-677.

[http://www.politicacriminal.cl/Vol_10/n_20/Vol10N20A7.pdf]

NEUMANN, Ulfried, "Individuelle und überindividuelle Begründung des Notwehrrechts", en: LÜDERSSEN ET AL (Eds.), Modernes Strafrecht und ultima-ratio Prinzip, Fráncfort del Meno: Peter Lang, 1990, pp. 215-226.

Nomos-Kommentar. Strafgesetzbuch, Tomo 1, editado por KINDHÄUSER/NEUMANN/PAEFFGEN, 4ª Edición, Baden-Baden: Nomos, 2013.

Nomos-Kommentar. Strafgesetzbuch, Tomo 1, editado por KINDHÄUSER/NEUMANN/PAEFFGEN, $3^{\text {a }}$ Edición, Baden-Baden: Nomos, 2010.

NAGLER, Johannes, "Der heutige Stand der Lehre der Rechtswidrigkeit", en: Festschrift für Karl Binding, Tomo II, Leipzig, 1911, pp. 273-385.

NOVOA, Eduardo, Curso de Derecho Penal Chileno, Tomo I, Tercera Edición, Santiago: Editorial Jurídica, 2005.

OTTO, Harro, Grundkurs Strafrecht. Allgemeiner Teil, $7^{\mathrm{a}}$ Edición, Berlín: De Gruyter, 2004.

Pflichtenkollision und Rechtswidrigkeitsurteil, $3^{\text {a }}$ Edición, Marburgo: Elwert, 1978.

PALERMO, Omar, La legítima defensa: una revisión normativista, Barcelona: Atelier, 2006.

PAWLIK, Michael, Der rechtfertigende Notstand, Berlín-Nueva York: De Gruyter, 2002. Das Unrecht des Bürgers, Tubinga: Mohr-Siebeck, 2013.

"Der rechtfertigende Defensivnotstand im System der Notrechte", Goltdammer's Archiv für Strafrecht 2003, pp. 12-24.

, "Der rechtfertigende Defensivnotstand", Jura 2002, pp. 26-31.

"Die Notwehr nach Kant und Hegel," Zeitschrift für die gesamte Strafrechtswissenschaft 2002, pp. 259-299.

"La legítima defensa según Kant y Hegel", en: MAÑALICH (Coord.), La antijuridicidad en el derecho penal, Buenos Aires: BdeF, 2013, pp. 4-64.

"Der wichtigste dogmatische Fortschritt der letzten Menschenalter? Anmerkungen zur Unterscheidung zwischen Unrecht und Schuld im Strafrecht”, en: DANNECKER ET AL (Eds.), Festschrift für Harro Otto zum 70. Geburtstag, Colonia-Berlin-Múnich, 2007, pp. 133-154.

"Die Aufhebung der Strafbarkeit", en: KOCH ET AL (Eds.), Feuerbachs

Bayerisches Strafgesetzbuch, Tubinga: Mohr-Siebeck, 2014, pp. 303-352.

PELZ, Christian, "Notwehr- und Notstandsrechte und der Vorrang obrigkeitlicher Hilfe", Neue Zeitschrift für Strafrecht 1995, pp. 305-309.

PUPPE, Ingeborg, Strafrecht Allgemeiner Teil im Spiegel der Rechtssprechung, $2^{\text {a }}$ Edición, Baden-Baden: Nomos, 2011.

"Rechtfertigung und Bestimmtheit", en: KUDLICH/MONTIEL/SCHUHR (Eds.), Gesetzlichkeit und Strafrecht, Berlín: Duncker \& Humblot, 2012, pp. 165-178. RENZIKOWSKI, Joachim, Notstand und Notwehr, Berlín: Duncker \& Humblot, 1994. "Intra- und extrasystematische Rechtfertigungsgründe", en: BYRD y JOERDEN (Eds.), Philosophia Practica Universalis; Festschrift für Joachim Hruschka zum 70. Geburtstag, Berlín: Duncker \& Humblot, 2005, pp. 643-658.

"Normentheorie und Strafrechtsdogmatik", en: ALEXY (Ed.), Juristische Grundlagenforschung, ARSP Beiheft 104, Stuttgart, 2005, pp. 115-137.

RICHTER, Heinrich Ferdinand, Das philosophische Strafrecht begründet auf die Idee der Gerechtigkeit, Leipzig, 1829. 
WILENMANN, Javier. "Injusto y agresión en la legítima defensa. Una teoría jurídica de la legítima defensa".

ROBLES PLANAS, Ricardo, Estudios de dogmática jurídico-penal, Montevideo/Buenos Aires: BdeF, 2014.

RODRÍGUEZ DEVESA, José María, Derecho Penal Español Parte General, Octava edición, Madrid, sin indicación de editorial, 1981.

ROXIN, Claus, Strafrecht Allgemeiner Teil. Band I, 4a Edición, Múnich: Beck, 2006. , Strafrecht Allgemeiner Teil. Band II, Múnich: Beck, 2003.

, Kriminalpolitik und Strafrechtssystem, $2^{\mathrm{a}}$ Edición, Berlín-Nueva York: De Gruyter, 1973.

, "Die 'sozialethischen Einschränkungen' des Notwehrrechts -Versuch einer Bilanz -",Zeitschrift für die gesamte Strafrechtswissenschaft 1981, pp. 68-104.

"Notwehr und Rechtsbewährung", en: HEGER/KELKER/SCHRAMM (Eds.), Festschrift für Kristian Kühl, Múnich: Beck, 2014, pp. 391-405.

SATZGER, Helmut; SCHMITT, Bertram; y WIDMAIER, Gunter (eds.), StGB. Strafgesetzbuch Kommentar Colonia: Carl Heymanns, 2009.

SILVA SÁNCHEZ, Jesús María, “¿Adiós a un concepto unitario de injusto en la teoría del delito?", InDret 3 (2014).

SCHAFFSTEIN, Friedrich, Die allgemeinen Lehren vom Verbrechen in ihrer Entwicklung durch die Wissenschaft des gemeinen Strafrechts, Aalen: Scientia Verlag, 1973 (reimpresión de la edición de Berlín, 1930).

SCHMIDHÄUSER, Eberhard, "Die Begründung der Notwehr”, Goltdammer's Archiv für Strafrecht 1991, pp. 97-139.

, Strafrecht Allgemeiner Teil, 2 ${ }^{\mathrm{a}}$ Edición, Tubinga: Mohr-Siebeck, 1975.

"Über die Wertstruktur der Notwehr", en: BARTH (Ed.), Festschrift für Richard

Honig, Gotinga: Schwartz, 1970, pp. 185-200.

Schönke/Schröder Strafgesetzbuch, editado por ESER ET AL, 29ª Edición, Múnich: Beck, 2014.

SEEBERG, Rouven, Aufgedrängte Nothilfe, Notwehr und Notwehrexzess, Fráncfort del Meno, 2004.

SEELMANN, Kurt, Das Verhältnis von $\S 34$ StGB zu anderen Rechtsfertigungsgründen, Heidelberg: v. Decker, 1978.

"Person, Norm", en: PAWLIK y ZACZYK (Eds.), Festschrift für Günther Jakobs, Colonia/Berlín/Múnich: De Gruyter, 2007, 635-644.

SEESKO, Tino, Notwehr gegen Erpressung durch Drohung mit erlaubtem Verhalten, Berlín: Duncker \& Humblot, 2004.

SENGBUSCH, René, Die Subsidiarität der Notwehr. Zum Verhältnis der eigenhändiger Verteidigung und der Abwehr eines Angriffs durch staatliche oder private Helfer, Berlín: Duncker \& Humblot, 2008.

SINN, Arndt, "Notwehr gegen nicht sorgfaltwidriges Verhalten", Goltdammer's Archiv für Strafrecht 2003, pp. 96-108.

, "Die Notwehr als Lotteriespiel", en: FAHL ET AL (Eds.), Festschrift für Werner Beulke, Múnich: Müller, 2015, pp. 271-281.

SOLER, Sebastián, Derecho Penal Argentino, Tomo I, $5^{\text {a }}$ Edición, 10 ${ }^{\mathrm{a}}$ Reimpresión, Buenos Aires: Tipográfica Editora Argentina, 1992.

SOWADA, Christoph, "Sind zwei Halbe ein Ganzes? Zur Addierbarkeit teilverwirklichter Fallgruppen bei den sozialethischen Notwehrbeschränkungen", en: PUTZKE ET AL (Eds.), Festschrift für Rolf Herzberg, Tubinga: Mohr-Siebeck, 2008, pp. 459-481. 
Polít. crim. Vol. 10, No 20 (Diciembre 2015), Art. 7, pp. 622-677.

[http://www.politicacriminal.cl/Vol_10/n_20/Vol10N20A7.pdf]

Strafgesetzbuch Leipziger Kommentar (LK11), segundo tomo, editado por JÄHNKE/LAUFHÜTTE/ODERSKY, 11 $1^{\mathrm{a}}$ edición, Berlin: De Gruyter, 2003.

STRATENWERTH, Günther, "Prinzipien der Rechtfertigung", Zeitschrift für die gesamte Strafrechtwissenschaft 68 (1956), pp. 41-70.

STRATENWERTH, Günther y KUHLEN, Lothar, Strafrecht Allgemeiner Teil, $6^{\text {a }}$ Edición, Múnich: Beck, 2011

THIEL, Sven-Markus, Die Konkurrenz von Rechtfertigungsgründen, Fráncfort del Meno: Peter Lang, 2000.

VAN RIENEN, Rafael, Die “sozialethischen” Einschränkungen des Notwehrrechts. Die Grenzen privater Rechtsverteidigung und das staatliche Gewaltmonopol, BadenBaden: Nomos, 2009.

VON DEN PFORDTEN, Dietmar, "Zu den Prinzipien der Notwehr", en: AMELUNG ET AL (Eds.), Festschrift für Hans-Ludwig Schreiber, Heidelberg: Müller, 2003, pp. 359-373.

WAGNER, Heinz, Individualistische oder überindividualistische Notwehrbegründung, Berlín: Duncker \& Humblot, 1984.

WILENMANN, Javier, Freiheitsdistribution und Verantwortungsbegriff. Die Dogmatik des Defensivnotstands im Strafrecht, Tubinga: Mohr-Siebeck, 2014.

"Injusto, justificación e imputación", en: MAÑALICH (Coord.), La antijuridicidad en el Derecho penal, Montevideo/Buenos Aires: BdeF, 2013, pp. 99176.

ZAFFARONI, Eugenio; SLOKAR, Alejandro; y ALAGIA, Alejandro, Derecho Penal Parte General, $2^{\mathrm{a}}$ Edición, Buenos Aires: Sociedad Anónima Editora, 2002.

ZIMMERMANN, Till, Rettungstötungen, Baden-Baden: Nomos, 2009. 